\title{
Greenhouse gas balances of managed peatlands in the Nordic countries - present knowledge and gaps
}

\author{
M. Maljanen ${ }^{1,2}$, B. D. Sigurdsson ${ }^{1}$, J. Guðmundsson ${ }^{1}$, H. Óskarsson ${ }^{1}$, J. T. Huttunen ${ }^{\dagger}$, and P. J. Martikainen ${ }^{2}$ \\ ${ }^{1}$ Agricultural University of Iceland, Keldnaholt, 112 Reykjavik, Iceland \\ ${ }^{2}$ University of Eastern Finland, Kuopio campus, Department of Environmental Science, P.O. Box 1627, \\ 70211 Kuopio, Finland \\ $\dagger$ deceased
}

Received: 29 May 2009 - Published in Biogeosciences Discuss.: 30 June 2009

Revised: 24 August 2010 - Accepted: 31 August 2010 - Published: 15 September 2010

\begin{abstract}
This article provides an overview of the effects of land-use on the fluxes of carbon dioxide $\left(\mathrm{CO}_{2}\right)$, methane $\left(\mathrm{CH}_{4}\right)$ and nitrous oxide $\left(\mathrm{N}_{2} \mathrm{O}\right)$ and from peatlands in the Nordic countries based on the field data from about 100 studies. In addition, this review aims to identify the gaps in the present knowledge on the greenhouse gas (GHG) balances associated with the land-use of these northern ecosystems. Northern peatlands have accumulated, as peat, a vast amount of carbon from the atmosphere since the last glaciation. However, the past land-use and present climate have evidently changed their GHG balance. Unmanaged boreal peatlands may act as net sources or sinks for $\mathrm{CO}_{2}$ and $\mathrm{CH}_{4}$ depending on the weather conditions. Drainage for agriculture has turned peatlands to significant sources of GHGs (mainly $\mathrm{N}_{2} \mathrm{O}$ and $\mathrm{CO}_{2}$ ). Annual mean GHG balances including net $\mathrm{CH}_{4}, \mathrm{~N}_{2} \mathrm{O}$ and $\mathrm{CO}_{2}$ emissions are 2260, 2280 and $3140 \mathrm{~g} \mathrm{CO}_{2}$ eq. $\mathrm{m}^{-2}$ (calculated using 100 year time horizon) for areas drained for grass swards, cereals or those left fallow, respectively. Even after cessetion of the cultivation practices, $\mathrm{N}_{2} \mathrm{O}$ and $\mathrm{CO}_{2}$ emissions remain high. The mean net GHG emissions in abandoned and afforested agricultural peatlands have been 1580 and $500 \mathrm{~g} \mathrm{CO}_{2}$ eq. $\mathrm{m}^{-2}$, respectively. Peat extraction sites are net sources of GHGs with an average emission rate of $770 \mathrm{~g} \mathrm{CO}_{2}$ eq. $\mathrm{m}^{-2}$. Cultivation of a perennial grass (e.g., reed canary grass) on an abandoned peat extraction site has been shown to convert such a site into a net sink of GHGs $\left(-330 \mathrm{~g} \mathrm{CO}_{2}\right.$ eq. $\left.\mathrm{m}^{-2}\right)$. In contrast, despite restoration, such sites are known to emit GHGs (mean source of $480 \mathrm{~g} \mathrm{CO}_{2}$ eq. $\mathrm{m}^{-2}$, mostly from high $\mathrm{CH}_{4}$ emissions). Peatland forests, originally drained for forestry, may act as
\end{abstract}

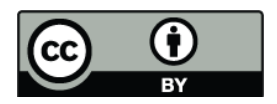

Correspondence to: M. Maljanen (marja.maljanen@uef.fi) net sinks (mean $-780 \mathrm{~g} \mathrm{CO}_{2}$ eq. $\mathrm{m}^{-2}$ ). However, the studies where all three GHGs have been measured at an ecosystem level in the forested peatlands are lacking. The data for restored peatland forests (clear cut and rewetted) indicate that such sites are on average a net $\operatorname{sink}\left(190 \mathrm{~g} \mathrm{CO}_{2}\right.$ eq. $\left.\mathrm{m}^{-2}\right)$. The mean emissions from drained peatlands presented here do not include emissions from ditches which form a part of the drainage network and can contribute significantly to the total GHG budget. Peat soils submerged under water reservoirs have acted as sources of $\mathrm{CO}_{2}, \mathrm{CH}_{4}$ and $\mathrm{N}_{2} \mathrm{O}$ (mean annual emission $240 \mathrm{~g} \mathrm{CO}_{2}$ eq. $\mathrm{m}^{-2}$ ). However, we cannot yet predict accurately the overall greenhouse gas fluxes of organic soils based on the site characteristics and land-use practices alone because the data on many land-use options and our understanding of the biogeochemical cycling associated with the gas fluxes are limited.

\section{Introduction}

\subsection{Carbon dioxide, methane and nitrous oxide as greenhouse gases}

Carbon dioxide $\left(\mathrm{CO}_{2}\right)$ is a greenhouse gas which transmits visible light but absorbs strongly infrared and near-infrared light, thereby trapping heat in the troposphere and heating the soil surface (Solomon et al., 2007). The other important greenhouse gases are nitrous oxide $\left(\mathrm{N}_{2} \mathrm{O}\right)$ and methane $\left(\mathrm{CH}_{4}\right) \cdot \mathrm{N}_{2} \mathrm{O}$ is a more efficient greenhouse gas than $\mathrm{CO}_{2}$. With a 100-year time horizon its global warming potential (GWP) is 298 times that of $\mathrm{CO}_{2}$ (Solomon et al., 2007). Ecosystems act either as sinks or sources of $\mathrm{CO}_{2}$ depending on the relative rates of photosynthesis and respiration.

Published by Copernicus Publications on behalf of the European Geosciences Union. 
Table 1. Peatland areas in the Nordic countries $\left(\mathrm{km}^{2}\right)$. The "original" area represents the peatland area before human disturbance and the "unmanaged" the present area of undrained peatlands.

\begin{tabular}{llllll}
\hline Soil use option & Finland & Sweden & Norway & Denmark & Iceland \\
\hline 1. Original & $104000^{\mathrm{a}}$ & $103000^{\mathrm{e}, \mathrm{f}}$ & $25000^{\mathrm{h}}$ & $10000^{\mathrm{j}}$ & $9000^{\mathrm{1}}$ \\
2. Unmanaged & $40000^{\mathrm{a}}$ & $49000^{\mathrm{e}}$ & $20000^{\mathrm{p}}$ & $910^{\mathrm{j}}$ & 4000 \\
3. Forestry drained & $57000^{\mathrm{a}}$ & $50000^{\mathrm{e}}$ & $4200^{\mathrm{i}}$ & $\mathrm{nd}$ & $6^{\mathrm{n}}$ \\
4. Agriculture & $850^{\mathrm{b}}$ & $3015^{\mathrm{f}}$ & $850^{\mathrm{p}}-1500^{\mathrm{h}}$ & $600^{\mathrm{j}}-1520^{\mathrm{q}}$ & $3750^{\mathrm{l}, \mathrm{o}}$ \\
4.1 Abandoned & $\mathrm{nd}$ & $4470^{\mathrm{f}}$ & $\mathrm{nd}$ & $\mathrm{nd}$ & $\mathrm{nd}$ \\
3-4.1 Restored & $<100$ & $12^{\mathrm{f}}$ & 0 & $109^{\mathrm{q}, \mathrm{r}}$ & $8^{\mathrm{m}}$ \\
4.2 Afforested & $850^{\mathrm{c}}$ & $\mathrm{nd}^{1}$ & $30^{\mathrm{h}}$ & $\mathrm{nd}$ & $19^{\mathrm{n}}$ \\
5. Peat extraction & $630^{\mathrm{a}}$ & $102-400^{\mathrm{g}}$ & 0 & $9^{\mathrm{q}}$ & 0 \\
5.1. Afforested & $52^{\mathrm{c}}$ & $\mathrm{nd}^{2}$ & 0 & $\mathrm{nd}$ & 0 \\
5.2.1 Energy crops & $19^{\mathrm{d}}$ & 0 & 0 & $\mathrm{nd}$ & 0 \\
5.2.2 Other crops & $\mathrm{nd}$ & 0 & 0 & $\mathrm{nd}$ & 0 \\
5.3. Restored & $<66^{\mathrm{a}}$ & 0 & 0 & $\mathrm{nd}$ & 0 \\
6. Water reservoirs & $600^{\mathrm{a}}$ & $12^{\mathrm{f}, 3}$ & $\mathrm{nd}$ & $\mathrm{nd}$ & $5^{1}$ \\
\hline
\end{tabular}

${ }^{\mathrm{a}}$ Turunen (2008), ${ }^{\mathrm{b}}$ Myllys and Sinkkonen (2004), not including mull soils, $2140 \mathrm{~km}^{2},{ }^{\mathrm{c}} \mathrm{J}$. Hytönen, Finnish Forest Research Institute, personal communication, 2009, ${ }^{\mathrm{d}}$ Hyvönen et al. (2009); the estimated area in 2012 is $100 \mathrm{~km}^{2},{ }^{\mathrm{e}}$ Hånell $(1990),{ }^{\mathrm{f}}$ Berglund and Berglund $(2008,2010)$ includes $2023 \mathrm{~km}^{2}$ deep peat, $501 \mathrm{~km}^{2}$ shallow peat, $489 \mathrm{~km}{ }^{2}$ gyttja soils, ${ }^{\mathrm{g}}$ SCB (2008), ${ }^{\mathrm{h}}$ Grønlund et al. (2006), ${ }^{\mathrm{i}}$ Paavilainen and Päivänen (1995), ${ }^{\mathrm{j}}$ Djurhuus et al. (2005), ${ }^{1} \mathrm{~J}$. Guðmundsson; Agricultural University of Iceland, personal communication, 2009, (including drained but abandoned after drainage, crop production, $650 \mathrm{~km}^{2}$ ), ${ }^{\mathrm{m}}$ Votlendisnefnd Landbúnaðarráðuneytisins, 2006 (including lakes and ponds $5 \mathrm{~km}{ }^{2}$ ), ${ }^{n}$ A. Snorrason, personal communication, 2009; data extracted from the database of Icelandic National Forest Inventory in 2010, ${ }^{\circ}$ The Environment Agency of Iceland (2008), p Norwegian Pollution Control Authority (2009) ${ }^{\mathrm{q}}$ Nielsen et al. (2009) including annual crops in rotation and set-a-side, grass in rotation and permanent grass accounted for 54\%, $11 \%, 16 \%$, and $18 \%$, respectively. $38 \%$ of the organic soils are according to the Danish soil classification deep organic soils, ${ }^{\mathrm{r}}$ Includes both restored wetlands $\left(68 \mathrm{~km}{ }^{2}\right)$, assumed to be only from agriculture and wetlands with elevated water table $\left(41 \mathrm{~km}^{2}\right)$ in 2005 . These wetlands are only reported to have been restored or rewetted on 27 and $13 \mathrm{~km}{ }^{2}$ organic soils, respectively; the remainder was established on mineral soil.

${ }^{1}$ Most of the abandoned peat fields are forested; ${ }^{2}$ Extraction area in 2002, the total area with permission to peat extraction is about $400 \mathrm{~km}^{2} ;{ }^{3}$ Restored wetlands includes artificial lakes; nd $=$ no data available

$\mathrm{N}_{2} \mathrm{O}$ is produced in soils mainly by microbial activities, nitrification and denitrification being the key processes (Priemé and Christensen, 2001). Methane $\left(\mathrm{CH}_{4}\right)$ is a greenhouse gas with 25 times the GWP of $\mathrm{CO}_{2}$ in a 100 -year time horizon (Solomon et al., 2007). $\mathrm{CH}_{4}$ is formed in soils through anaerobic processes regulated by methanogenic microbes (e.g. Le Mer and Roger, 2001). Concentrations of $\mathrm{CO}_{2}, \mathrm{CH}_{4}$ and $\mathrm{N}_{2} \mathrm{O}$ in the atmosphere have increased since pre-industrial times due to anthropogenic activities. In addition to the use of fossil fuels, land-use change from forest to agriculture is among the key factors (Solomon et al., 2007). Concentrations of $\mathrm{CO}_{2}, \mathrm{CH}_{4}$ and $\mathrm{N}_{2} \mathrm{O}$ in the atmosphere were $37 \%, 156 \%$ and $19 \%$ above the pre-industrial levels in 2007 (WMO, 2008).

\subsection{Peatlands and their use in the Nordic countries}

Boreal and subarctic peatlands are large carbon (C) reservoirs containing about $20 \%$ of the global terrestrial C-stock in their aboveground biomass and belowground organic matter (OM) (Post et al., 1982; Janzen, 2004). OM accumulates as peat in the anaerobic, waterlogged soils as a result of the slow and incomplete decomposition. About 350 million ha of the peatlands are at high latitudes (Starck, 2008; Turunen et al., 2002). During the postglacial period boreal and subarctic peatlands have accumulated about $455 \mathrm{Pg} \mathrm{C}$ (Gorham, 1991), which means that $1670 \mathrm{Pg} \mathrm{CO}_{2}$ have been removed from the atmosphere during this period. This can be compared to the total $\mathrm{CO}_{2}$ stored in the atmosphere at any given time, which has been estimated to be ca. $750 \mathrm{Pg} \mathrm{C}(2750 \mathrm{Pg}$ as $\mathrm{CO}_{2}$ ) (Solomon et al., 2007).

There has been a major decrease in the area of pristine peatlands in all the Nordic countries. Peat soils have been drained for forestry, croplands, pastures and rangelands, peat mining, and for infrastructure such as roads and settlements (Table 1). The present fractions of unmanaged peatlands in the Nordic countries range from 9\% (Denmark) to $80 \%$ (Norway) of the original peatland area (Table 1). Drainage has therefore affected the overall carbon and nitrogen cycles of peatlands differently in the countries under consideration. However, there are no accurate estimates for the coverage of all land-use options, including e.g. the various after-use options of abandoned peat extraction sites and abandoned croplands (Table 1).

In Finland and Sweden, peatlands have been drained intensively for forestry, about $55 \%$ and $15 \%$ of the original peatland areas, respectively (Paavilainen and Päivänen, 1995; Vasander et al., 2003). In these countries, about $10 \%$ of the 
peatlands have been used for agriculture (Myllys and Sinkkonen, 2004; Berglund and Berglund, 2010). Also in Norway about $10 \%$ of drained peatlands are used for agriculture and the remaining part of drained peatlands is mainly used for forestry (Grønlund et al., 2008). In Iceland, more than half of the peatlands have been drained, but less than $20 \%$ of those are used for cultivation (The Environment Agency of Iceland, 2009). There, the majority of drained peatlands is either abandoned (as uncultivated) or used for livestock grazing. The origin of forests on peatlands in Sweden is poorly known. Probably, more than one third of the present peatland forests in Sweden have originally been agricultural land (von Arnold et al., 2005a). In Denmark and Iceland only a minor part of the peatlands are used for forestry, agriculture being the main use of drained peatlands (Table 1). Also, the classification of peatlands differs among countries. In Sweden and Denmark, the organic soils are classified as shallow $(<50 \mathrm{~cm})$ and deep peat soils $(>50 \mathrm{~cm})$ (Berglund and Berglund, 2010). In Sweden, all soils with OM content $>20 \%$ and the depth of the peat layer $>30 \mathrm{~cm}$ are peat soils (Eriksson et al., 2005), whereas in Finland soils with $>40 \%$ OM are classified as peat (Myllys and Sinkkonen, 2004) and soils with OM content from 20 to 39.9\% are classified organic mull soils (Myllys and Sinkkonen, 2004). In Sweden "Gyttja" soils with OM content between 6 and $20 \%$ are also classified as organic soils (Eriksson et al., 2005; Berglund and Berglund, 2010).

In general, the area of former peatlands used for agriculture is difficult to identity based on the present soil properties, since with time the cultivated peat soils are converted into mull or mineral soils (Myllys and Sinkkonen, 2004). For example, in Finland there are at present $850 \mathrm{~km}^{2}$ of agricultural soils classified as peat soils but, in addition, $2140 \mathrm{~km}^{2}$ of drained organic soils are classified as mull soils (Myllys and Sinkkonen, 2004).

In Finland and Sweden, drainage of new areas for forestry and agriculture is no longer a common practice. In Iceland, some new areas are still being drained for agriculture (J. Guðmundsson, Agricultural University of Iceland, personal communication, 2009). In Finland, the maintenance of the existing drained forested sites requires cleaning of the ditches (Paavilainen and Päivänen, 1995). Forestry and agriculture are not the only anthropogenic activities changing the function of peatlands. Peatlands have been used either as livestock pastures or rangelands, for construction of roads and other infrastructures. Also, artificial lakes have been constructed on peatlands (Turunen, 2008; Berglund and Berglund, 2008; Óskarsson and Guðmundsson, 2008a). Historically, peat extraction for energy and other purposes has been carried out in all Nordic countries. At present, only Finland and Sweden have large-scale peat extraction activities. In Finland and Sweden the area used for peat extraction is $0.6 \%$ and $0.1 \%$ of the total peatland area, respectively (Turunen, 2008; SCB, 2004; 2008). In these countries, large areas of the extraction sites are annually removed from extraction, and new extraction areas are established on pristine peatlands or on previously drained sites, e.g. on forestry drained peatlands. Until now, a small area of the abandoned peat extraction sites has been afforested in Finland, however, this land-use option is increasing (Paavilainen and Päivänen, 1995). In Iceland, peat has been extracted as a fuel for cooking, house heating and also as a construction material over many centuries. This usage stopped mostly in the early 20th century and no peat extraction has been carried out in Iceland since 1950 (NN, 1965). However, in recent years the excavation of peat due to the expansion of settlement has increased in Iceland. The excavated peat is often used on areas denuded by erosion or in landscape construction (The Environment Agency of Iceland, 2008).

The area of peat soils used for croplands is decreasing in Finland and Sweden. Some peat soils are annually abandoned and left out of crop production and some are converted eventually into mull or mineral soils in the course of time (Myllys and Sinkkonen, 2004). In Sweden about $2500 \mathrm{~km}^{2}$ of $6970 \mathrm{~km}^{2}$ drained for agriculture are still used for agricultural purposes (Hjertestedt, 1946; Berglund and Berglund, 2008, 2010). In Finland, more peat soils have been removed from agriculture with only $850 \mathrm{~km}^{2}$ of the original $5000 \mathrm{~km}^{2}$ presently under agricultural use (Myllys and Sinkkonen, 2004). This trend continues and arable peat soils are withdrawn from farming, e.g. for forestry (Paavilainen and Päivänen, 1995). In Iceland, by contrast, cultivation of peatland is increasing in many areas due to enlargement of dairy farms and increased barley cultivation as the climate has become warmer in the past two decades (Björnsson et al., 2008). This increase takes place on both previously drained peatlands and new drainages. The large portion of the drained peatlands in Iceland with low or no utilization at all has lead to the inclusion of wetland restoration in its in climate policy (Ministry for the Environment, 2007; UNFCCC, 2008).

Afforestation of abandoned croplands has been carried out in Finland, where more than $20 \mathrm{~km}^{2}$ of drained peatlands are afforested annually (J. Hytönen, Finnish Forest Research Institute, personal communication, 2009). The most common land-use option after peat extraction for has been afforestation, but the cultivation of reed canary grass (Phalaris arundinacea) for bioenergy is also increasing in Finland (Shurpali et al., 2009). In Iceland, the total afforested areas cover ca. $300 \mathrm{~km}^{2}$ (in year 2005) and afforested peatlands cover $11 \%$ of that, $32 \mathrm{~km}^{2} .6 \mathrm{~km}^{2}$ of the afforested peatlands are forestry drained, $19 \mathrm{~km}^{2}$ are agriculture drained, afforested soils, and the remaining $7 \mathrm{~km}^{2}$ are undrained marginal wetland soils, but still classified as "wetland" (called "hálfdeigja" or "jaðar" in Icelandic; A. Snorrason, personal communication, 2009. Data extracted from the database of Icelandic National Forest Inventory). 
Restoration of peatlands to their natural state by raising the water table level is also an after-use option. Restoration of drained croplands has been carried out in a small scale in Iceland (only those drained but not used for cultivation), in Norway and in Denmark.

\subsection{Greenhouse gas fluxes in unmanaged and drained peatlands}

Since the last glaciation period, unmanaged peatlands have on average acted as a sink for atmospheric $\mathrm{CO}_{2}$ (Turunen et al., 2002). However, during years with a dry growing season they can lose stored carbon as $\mathrm{CO}_{2}$ (e.g. Alm et al., 1999a). Hydrological conditions have a great impact on the carbon balance of unmanaged peatlands and the $\mathrm{CO}_{2}$ balances of various peatlands differ in their sensitivity towards climatic variability (Alm et al., 1997, 1999a; Shurpali et al., 1995; Sagerfors et al., 2008). In addition to $\mathrm{CO}_{2}, \mathrm{~N}_{2} \mathrm{O}$ and $\mathrm{CH}_{4}$ are the two other greenhouse gases which determine the atmospheric impact of peatlands. The dynamics of these two gases are also highly dependent on peatland hydrology.

Drainage of unmanaged peat soils, e.g. for forestry, agriculture or peat extraction, greatly changes their GHG dynamics (e.g. Martikainen et al., 1993; Hargreaves et al., 2003). After drainage, the decomposition of organic matter increases and the sites may turn from a carbon sink to net sources of $\mathrm{CO}_{2}$. The GHG fluxes of drained peat soils depend on soil properties (Klemedtsson et al., 2005), ground water level (e.g. Óskarsson, 1998; Martikainen et al., 1993) and management practices, e.g. fertilization and ploughing (e.g. Regina et al., 1998; Maljanen et al., 2003a,b).

Water saturated peat soils emit $\mathrm{C}$ as methane (Saarnio et al., 2007). When the availability of oxygen in peat increases after drainage, there is a decrease in $\mathrm{CH}_{4}$ emissions resulting from a decrease in $\mathrm{CH}_{4}$ production and an increase in oxidation of $\mathrm{CH}_{4}$ by methane oxidizing microbes (Saarnio et al., 2007; Le Mer and Roger, 2001). Drained peat soils are often only minor sources or sometimes small sinks of $\mathrm{CH}_{4}$ (Maljanen et al., 2007a; Mäkiranta et al., 2007).

Unmanaged peatlands generally have negligible emissions of $\mathrm{N}_{2} \mathrm{O}$ and they can even act as a sink for this gas (e.g. Regina et al., 1996; Martikainen et al., 1993). However, some nutrient rich unmanaged peatlands, i.e. herb-rich spruce mires and alder forests emit $\mathrm{N}_{2} \mathrm{O}$, (Huttunen et al., 2003; von Arnold et al., 2005c). A recent study by Repo et al. (2009) reveals that arctic peatlands have bare surfaces that also emit $\mathrm{N}_{2} \mathrm{O}$ at high rates. These high-emitting bare surfaces are created by cryogenic processes which do not exist in boreal peatlands, but these surfaces may exist in northern Scandinavia and in Iceland.

Peatland drainage increases the availability of oxygen and mineral nitrogen, which favours $\mathrm{N}_{2} \mathrm{O}$ production (e.g. Martikainen et al., 1993). Drained organic soils with high $\mathrm{N}_{2} \mathrm{O}$ emissions may have great importance on the atmospheric $\mathrm{N}_{2} \mathrm{O}$ load at national level, especially in countries with large areas of drained peatlands. For example, organic soils drained for agriculture are responsible for $25 \%$ of the anthropogenic $\mathrm{N}_{2} \mathrm{O}$ emissions in Finland (Kasimir Klemedtsson et al., 1997), even though they cover less than $10 \%$ of the total arable land area.

\subsection{GHG emissions from water reservoirs}

Reservoirs (i.e., man-made lakes) have been constructed to store water for different purposes, such as electrical power generation, water supply and flood control. In northern regions, such as in Finland, this has also meant flooding of unmanaged peatland ecosystems (e.g. Turunen, 2008). The reservoirs have been estimated to represent a significant world-wide source of atmospheric $\mathrm{CO}_{2}$ and $\mathrm{CH}_{4}$ (St. Louis et al., 2000). Data on the exchange of $\mathrm{N}_{2} \mathrm{O}$, the third most important GHG in reservoirs, are sparse. However, the results available suggest that the importance of $\mathrm{N}_{2} \mathrm{O}$ in the total GHG emissions from reservoirs is small (Huttunen et al., 2002b; Huttunen and Martikainen, 2005a; Óskarsson and Guðmundsson, 2008a,b).

$\mathrm{CO}_{2}$ and $\mathrm{N}_{2} \mathrm{O}$ are released from reservoirs to the atmosphere mainly by diffusion (and by turbulence) at the waterair interface, while $\mathrm{CH}_{4}$ can be transported by diffusion, ebullition (bubbling) and/or through aerenchymatous tissues of aquatic macrophytes. In northern, seasonally ice-covered reservoirs, GHGs produced during wintertime accumulate in the water column under the ice. It has been suggested that these gas stores are largely released to the atmosphere during spring overturn after the ice melt (Huttunen et al., 2002b; Duchemin et al., 2006). Dissolved GHGs can also exit reservoirs in outflowing water, causing possible "degassing emissions" downstream of the dam, within turbine/spillway constructions and/or in lower river reaches (Roehm and Tremblay, 2006; Guerin et al., 2006).

At present, most of the data on reservoir GHG emissions are from tropical countries such as Brazil and French Guiana, and from the boreal zone in Canada (e.g. Soumis et al., 2004). In the Nordic countries, there are published data on the reservoir $\mathrm{CO}_{2}, \mathrm{CH}_{4}$ and $\mathrm{N}_{2} \mathrm{O}$ fluxes from Finland, $\mathrm{CO}_{2}$ fluxes from Sweden (Bergström et al., 2004; Åberg et al., 2004) and on $\mathrm{CH}_{4}$ and $\mathrm{N}_{2} \mathrm{O}$ (Óskarsson and Guðmundsson, 2008b) and $\mathrm{CO}_{2}$ (Óskarsson and Guðmundsson, 2008a) fluxes from Iceland. Some preliminary results have been presented for GHG exchange in small reservoirs in Norway (Harby et al., 2006).

Measured fluxes of GHG from reservoirs can generally not be interpreted as connected to specific type of land impounded e.g. peatland, since dissolved gasses from different submerged land types are mixed into the water body.

\subsection{Aims}

There is an urgent need to develop mitigation strategies to reduce GHG emissions. This was highlighted by the 
ratification of the Kyoto Protocol in 2004. At present, afforestation, forest management, cropland management and grazing land management are valid mitigation options for drained peatlands according to the Kyoto protocol, and it is being discussed whether wetland restoration and biomass production for bioenergy could also be accepted as valid mitigation options in the next commitment period in 2013-2017.

There are large uncertainties regarding the true potential of different land-use options to mitigate GHG emissions. In this review we summarize the present knowledge on how the various land-use options affect the GHG fluxes of peatlands in the Nordic countries. The data used for this review are taken mainly from studies in Denmark, Finland, Iceland and Sweden. The research groups from thse countries participated in a large Nordic project entitled: The Nordic Centre for Studies of Ecosystem Carbon Exchange and its Interactions with the Climate System (NECC). NECC was funded between 2003 and 2008 by the Nordic Centre of Excellence (NCoE) Pilot Programme. We used mostly published experimental data, but some unpublished data is also included. Based on this wealth of data, we have identified the most serious gaps in present knowledge regarding the GHG fluxes of managed peatlands. The land-use categories discussed in this review were (1) unmanaged peatlands, (2) peatlands drained for forestry, (3) peatlands drained for agriculture, (4) peat extraction sites and (5) flooding of peatlands for water reservoirs. The various land-use options (e.g. rewetting, afforestation, energy crops) for peat soils withdrawn from current land-use were compared.

\section{Data sources from various managed peatland ecosystems}

\subsection{Measurement techniques for terrestrial $\mathrm{CH}_{4}, \mathrm{CO}_{2}$ and $\mathrm{N}_{2} \mathrm{O}$ fluxes}

Fluxes of $\mathrm{CH}_{4}, \mathrm{CO}_{2}$ and $\mathrm{N}_{2} \mathrm{O}$ are measured using various chamber techniques (e.g. Nykänen et al., 1995); micrometeorological methods (e.g. Lohila et al., 2004) or the fluxes can be calculated from the gas concentration gradients in snow or soil using the diffusion approach (Alm et al., 1999b; Maljanen et al., 2003c). Static chamber techniques determine the gas fluxes from the change in gas concentration in the headspace of the chamber with time. Dynamic chamber techniques determine the flux rate based on the equilibrium in the gas concentration in the chamber with equal gas flow rates into and from the chamber. The gas concentrations are measured e.g. by gas chromatograph (electron capture-, thermal conductivity- and flame ionization-detectors for $\mathrm{N}_{2} \mathrm{O}, \mathrm{CO}_{2}$ and $\mathrm{CH}_{4}$, respectively), infrared analyzer or photo-acoustic analyzer, recently also by laser analyzers. The most commonly used micrometeorological method is the eddy covariance (EC) method, where the gas flux is determined from the high-frequency measurements of gas concentration, wind and scalar atmospheric data series. Gas concentrations are measured with a high-frequency infrared analyzer or tunable diode laser absorption spectrometer. This method provides continuous, spatially integrated fluxes from large areas (e.g. Baldocchi et al., 1988; Lohila et al., 2003, 2007a,b). It can be used to measure the net ecosystem exchange of $\mathrm{CO}_{2}$ (e.g. over forest canopy) over long periods. This net exchange is difference between the ecosystem respiration and $\mathrm{CO}_{2}$ uptake; it includes the $\mathrm{CO}_{2}$ produced during respiration of plants, soil animals and microbes and also $\mathrm{CO}_{2}$ uptake by photosynthesis. The net $\mathrm{CO}_{2}$ exchange can be estimated also by a chamber method (e.g. Alm et al., 1997; Maljanen et al., 2001a).

The EC method has also been applied for the $\mathrm{CH}_{4}$ and $\mathrm{N}_{2} \mathrm{O}$ fluxes (Clement et al., 1995; Pihlatie et al., 2005).

\subsection{Annual greenhouse gas fluxes of peatland ecosystems}

About 100 published articles or manuscripts reporting GHG fluxes from different land-use categories of peatlands are summarized for the Nordic countries. The available annual data on the fluxes is listed in Tables 2, 3, 4 and 5. In this summary, the minus sign indicates uptake of gas and the plus sign shows loss of gas from the ecosystem. If a site has flux data for several years, the average flux of these years is shown. If the flux data covers only the growing season, the annual fluxes are then calculated based on the published general gas dynamics in various seasons. For methane, the winter (= outside growing season) fluxes are estimated to be $15 \%$ of the growing season fluxes (Saarnio et al., 2007). Winter time respiration is assumed to be $15 \%$ of the growing season respiration or $210 \mathrm{~g} \mathrm{CO}_{2} \mathrm{~m}^{-2} \mathrm{yr}^{-1}$ (if respiration data is not available) for drained sites (Lohila et al., 2007; Shurpali et al., 2008) and $110 \mathrm{~g} \mathrm{CO}_{2} \mathrm{~m}^{-2} \mathrm{yr}^{-1}$ for the undrained sites (Saarnio et al., 2007). The winter time $\mathrm{N}_{2} \mathrm{O}$ emissions from drained peat soils may account for 1 to $99 \%$ of the annual ones, on average 40\% (Maljanen et al., 2004, 2007a). Therefore, winter nitrous oxide emissions for the drained sites were estimated to be $50 \%$ of the growing season emissions, which is likely to be a conservative estimate. If emissions are reported for growing seasons longer than six months, the fluxes are normalized to six months and winter is assumed to cover the rest of the year. This is the approach we have adopted to fill the gaps in data.

\subsection{Greenhouse gas emissions from aquatic systems}

The measurement methods for GHG fluxes in aquatic systems differ only slightly from those used in terrestrial sites (see above). Both the eddy covariance (EC) and chamber methods are used in the reservoir GHG flux studies. $\mathrm{CH}_{4}$ ebullition (bubbling) should be detected parallel to diffusive (turbulent) $\mathrm{CH}_{4}$ exchange. The diffusive/turbulent gas transfer rates can be calculated from the surface water GHG 
concentration gradient and local wind speed using the socalled "thin boundary layer method". The springtime GHG emissions, caused by the mixing of the water column following the spring ice melt, can be approximated from excess GHG storages accumulated under the ice during the icecovered season, since reaching the sites at the times of ice melt is difficult (e.g. Huttunen et al., 2002b).

\section{Synthesis of the data for the annual greenhouse gas balances in the Nordic countries}

\subsection{Unmanaged peatlands}

Greenhouse gas fluxes of unmanaged boreal or subarctic peatlands have been studied intensively. These data are more complete than for managed peatlands. However, there are no GHG data on undrained, grazed peatlands in Iceland, the most common land use there. In a review by Saarnio et al. (2007) on the $\mathrm{CO}_{2}$ and $\mathrm{CH}_{4}$ fluxes from boreal peatlands, the data are grouped into ombrotrophic (nutrient poor) and minerotrophic (nutrient rich) mire types. $\mathrm{N}_{2} \mathrm{O}$ fluxes of unmanaged peat soils (24 sites altogether) are taken from studies by Martikainen et al. (1993), Nykänen et al. (1995), Regina et al. (1996), Huttunen et al. (2002a), von Arnold et al. (2005b), and Kløve et al. (2010). These data and additional data by Saarnio et al. (2007) are summarized in Fig. 1. The spruce swamps (Huttunen et al., 2002a) and alder sites (von Arnold et al., 2005c) form a special group among the unmanaged peatlands. These have been excluded in determining the mean $\mathrm{N}_{2} \mathrm{O}$ fluxes of unmanaged peatlands with a high water table (WT) level. Some recent $\mathrm{CO}_{2}$ data (Nykänen et al., 2003; Aurela et al., 2007; Bäckstrand et al., 2010; Sagerfors et al., 2008; Lund et al., 2007; Nilsson et al., 2008; Soini et al., 2009) from unmanaged peatlands, not included in the review by Saarnio et al. (2007), are discussed separately.

Carbon gas fluxes $\left(\mathrm{CH}_{4}\right.$ and $\left.\mathrm{CO}_{2}\right)$ of unmanaged boreal peatlands vary greatly depending on weather conditions, e.g. timing of snowmelt (Aurela et al., 2004), and the geographical location of the site. According to the review by Saarnio et al. (2007), the average ( \pm standard deviation) net $\mathrm{CO}_{2}$ exchange for the boreal ombrotrophic peatlands is $55 \pm 190 \mathrm{~g} \mathrm{CO}_{2} \mathrm{~m}^{-2} \mathrm{yr}^{-1}$ and that for the minerotrophic peatlands is $-55 \pm 230 \mathrm{~g} \mathrm{CO}_{2} \mathrm{~m}^{-2} \mathrm{yr}^{-1}$. Thus, according to the existing data the ombrotrophic peatlands, in contrast to the minerotrophic ones, are net sources of $\mathrm{CO}_{2}$ to the atmosphere. Mean methane emissions were $6.7 \pm 5.3$ and $17.3 \pm 13.3 \mathrm{~g} \mathrm{CH}_{4} \mathrm{~m}^{-2} \mathrm{yr}^{-1}$ from ombrotrophic and minerotrophic peatlands, respectively (Saarnio et al., 2007). The total carbon gas fluxes $\left(\mathrm{CO}_{2}+\mathrm{CH}_{4}\right)$ of the ombrotrophic peatlands indicate a lower $\mathrm{C}$ accumulation rate for the ombrotrophic peatlands than for the minerotrophic peatlands (Saarnio et al., 2007). Some recent results have shown even higher $\mathrm{CO}_{2}$ uptake rates for boreal minerotrophic mires than

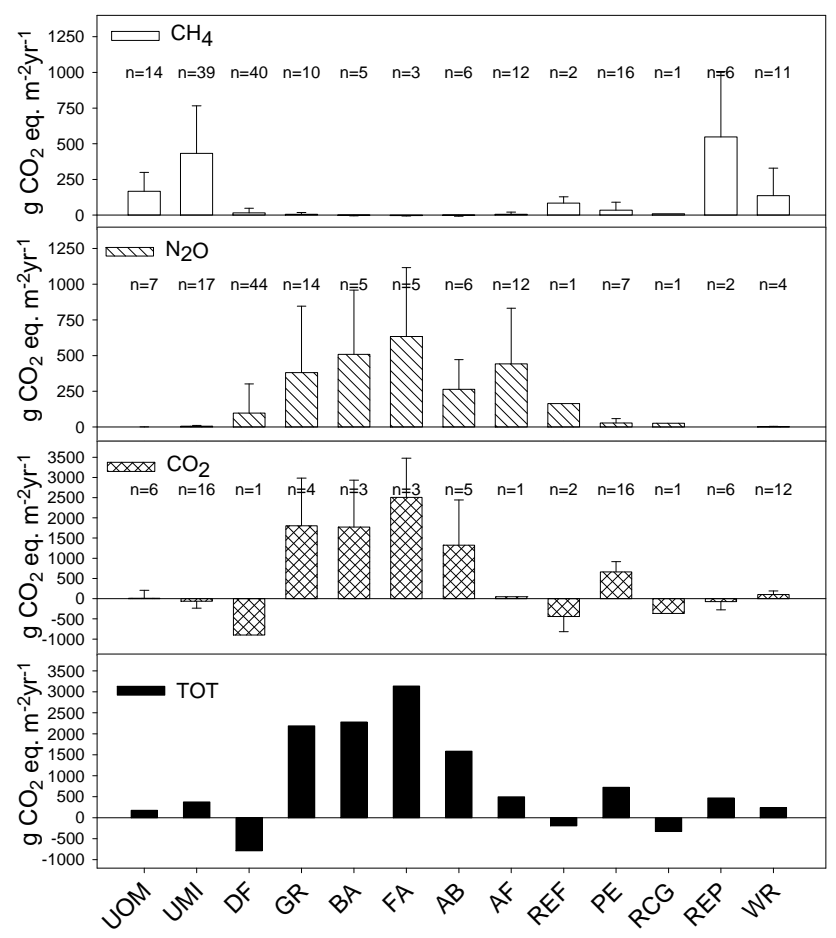

Fig. 1. The mean values of reported annual net fluxes of $\mathrm{CH}_{4}$, $\mathrm{N}_{2} \mathrm{O}$ and $\mathrm{CO}_{2}$ exchange and the net effect of these gases as $\mathrm{g} \mathrm{CO}_{2}$ equivalents $\mathrm{m}^{-2}$ (100-year time horizon) from different peatland categories in the Nordic countries (UOM=undrained ombrotrophic peatlands and $\mathrm{UMI}=$ undrained minerotrophic peatlands (from Saarnio et al., 2007), DF=ombrotrophic and minerotrophic sites drained for forestry, GR = drained for agriculture - grass, BA=agriculture - barley, FA=agriculture fallow, $\mathrm{AF}=$ agriculture - afforested, $\mathrm{AB}=$ agriculture - abandoned, $\mathrm{REF}=$ forestry - restored, $\mathrm{PE}=$ drained for peat extraction, $\mathrm{PEF}=$ peat extraction - afforested, $\mathrm{RCG}=$ abandoned peat extraction - cultivation of reed canary grass, $\mathrm{REP}=$ drained for peat extraction - restored, $\mathrm{WR}=$ water reservoirs). A negative value indicates uptake by the ecosystem and a positive value net emission, $n=$ number of sites, error bars indicate standard deviation between sites.

the data reviewed by Saarnio et al. (2007). The results from Saarnio et al. (2007) differs from the long term carbon accumulation rate (Turunen et al., 2002), showing higher C accumulation in the ombrotrophic than in the minerotrophic peatlands. This contradiction may be a result of spatial and temporal variation in the gas fluxes not covered completely by the available flux data. For example, the data from Alm et al. (1999a) originated from an exceptionally dry summer which probably turned the ombrotrophic (bog) site to net source of $\mathrm{C}$. Methane emission rates in unmanaged peatlands also vary with the WT depth, they are low during a dry growing season and may increase during a wet season (e.g. Nykänen et al., 2003). 
In recent studies unmanaged peatlands have most often been sinks for $\mathrm{CO}_{2}$. The average net $\mathrm{CO}_{2}$ exchange (negative value indicating uptake by the ecosystem) of Swedish nutrient poor peatland sites has been found to range between $-78 \mathrm{~g} \mathrm{CO}_{2} \mathrm{~m}^{-2} \mathrm{yr}^{-1}$ (Lund et al., 2007) and $-202 \mathrm{~g} \mathrm{~m}^{-2} \mathrm{yr}^{-1}$ (Sagerfors et al., 2008). In a Swedish minerotrophic site, the mean $\mathrm{CO}_{2}$ exchange was $-189 \mathrm{~g} \mathrm{~m}^{-2} \mathrm{yr}^{-1}$ (Nilsson et al., 2008). Bäckstrand et al. (2010) reported an annual $\mathrm{CO}_{2}$ balance of $-9.5 \mathrm{~g} \mathrm{~m}^{-2}$ for subarctic mire in northern Sweden and Nykänen et al. (2003) reported annual $\mathrm{CO}_{2}$ exchange rates from -508 to $-135 \mathrm{~g} \mathrm{~m}^{-2}$ for a subarctic palsa mire during climatically different years. Haapala et al. (2009) measured a seasonal $\mathrm{CO}_{2}$ exchange of -158 to $-136 \mathrm{~g} \mathrm{~m}^{-2}$ from April to December for a flark surface of a fen in northern Finland and Soini et al. (2009) reported seasonal (May to September) net $\mathrm{CO}_{2}$ exchange of $-390 \mathrm{~g} \mathrm{~m}^{-2}$ for a fen in Southern Finland. For a minerotrophic peatland in northern Finland the annual net fluxes were from -188 to $-219 \mathrm{~g} \mathrm{CO}_{2} \mathrm{~m}^{-2}$ (Aurela et al., 2007). If these results were also taken into account, the mean annual net $\mathrm{CO}_{2}$ sink for the minerotrophic peatlands in Finland and Sweden is higher than the values reported by Saarnio et al. (2007) and the net C loss from the ombrotrophic sites is lower than that reported in Saarnio et al. (2007).

The water table level affects $\mathrm{N}_{2} \mathrm{O}$ emissions from peatlands (e.g. Martikainen et al., 1993). Emissions can be high with a low WT level but water saturated peat can even consume atmospheric $\mathrm{N}_{2} \mathrm{O}$ in the absence of $\mathrm{O}_{2}$ (Huttunen et al., 2002a; Martikainen et al., 1993). The mean annual $\mathrm{N}_{2} \mathrm{O}$ emissions from undrained peatlands are low, $<0.001 \mathrm{~g} \mathrm{~N}_{2} \mathrm{O} \mathrm{m}^{-2}(n=7)$ for the ombrotrophic sites and $0.018 \pm 0.019 \mathrm{~g} \mathrm{~N}_{2} \mathrm{O} \mathrm{m}^{-2}(n=17)$ for the minerotrophic sites (Regina et al., 1996; Martikainen et al., 1993; Huttunen et al., 2002a; Nykänen et al., 1995; von Arnold et al., 2005b; Klöve et al., 2010) as a result of high WT level. Exceptions are the unmanaged herb-grass spruce mires (Huttunen et al., 2002a) and alder forests (von Arnold et al., 2005b) with a lower WT level. The annual $\mathrm{N}_{2} \mathrm{O}$ emissions in these sites were 0.25 and $0.10 \mathrm{~g} \mathrm{~m}^{-2}$, respectively. Especially in the spruce mires, the $\mathrm{N}_{2} \mathrm{O}$ emissions can be similar or even higher than those from peatlands drained for forestry. It is noteworthy that these unmanaged sites with high emission rates are not included in the estimate for the mean $\mathrm{N}_{2} \mathrm{O}$ emission from unmanaged minerotrophic sites (Fig. 1). When using the GWP approach with 100 years reference period $\left(\mathrm{CO}_{2}\right.$ eq. $)$ to calculate the atmospheric effect of the three greenhouse gases in the unmanaged peatlands, mainly $\mathrm{CH}_{4}$ causes the positive GWP (emission) for the minerotrophic peatlands and $\mathrm{CO}_{2}$ with $\mathrm{CH}_{4}$ for the ombrotrophic peatlands. The effect of $\mathrm{N}_{2} \mathrm{O}$ is insignificant (Fig. 1). In Fig. 1, the $\mathrm{CO}_{2}$ and $\mathrm{CH}_{4}$ data for unmanaged peatlands are from a review by Saarnio et al. (2007) and the $\mathrm{N}_{2} \mathrm{O}$ data from other studies mentioned above.

\subsection{Drained peat soils}

\subsubsection{Peatlands drained for forestry}

Drainage of peatlands for forestry usually differs from drainage for agriculture in the Nordic countries; the ditches are open and draining intensity is partly achieved by excavating secondary ditches connected to the main ditches (Paavilainen and Päivänen, 1995). For the forestry drained peatlands there are GHG flux data in Finland and Sweden, where large peatland areas have been drained to improve forest productivity (Table 2). In addition, one study has been carried out in Denmark but none in Norway and Iceland. Results from 65 study sites are included in Table 2, where the forestry drained peatlands are divided into ombrotrophic (nutrient poor) and minerotrophic (nutrient rich) sites.

Fluxes of $\mathrm{N}_{2} \mathrm{O}$ and $\mathrm{CH}_{4}$ have been measured with chamber methods from the forest floor. These fluxes have been intensively studied in Finland and Sweden. However, few data on net ecosystem $\mathrm{CO}_{2}$ exchange measured using the $\mathrm{EC}$ technique are available from such sites.

The depth of WT after drainage largely determines the $\mathrm{CH}_{4}$ flux rates. In general, the drainage changes the $\mathrm{CH}_{4}$ fluxes less in the ombrotrophic than in the minerotrophic peatlands because WT is less sensitive to drainage in ombrotrophic sites (Nykänen et al., 1998). Drainage decreases $\mathrm{CH}_{4}$ emissions of ombrotrophic sites on average by $50 \%$, whereas many of the high-emitting minerotrophic peatlands show $\mathrm{CH}_{4}$ uptake after drainage (Nykänen et al., 1998). Annual mean ( \pm standard deviation) $\mathrm{CH}_{4}$ emissions from ombrotrophic and minerotrophic peatlands drained for forestry are $1.24 \pm 1.64 \mathrm{~g} \mathrm{~m}^{-2}(n=9)$ and $0.59 \pm 1.36 \mathrm{~g} \mathrm{~m}^{-2}(n=29)$, respectively.

$\mathrm{N}_{2} \mathrm{O}$ fluxes in ombrotrophic peatlands are less affected by drainage than those in minerotrophic peatlands. In addition to the WT, $\mathrm{N}_{2} \mathrm{O}$ emissions are highly regulated by the $C / N$ ratio of peat. High emissions require a low $C / N$ ratio, from 15 to 25, in peat (Klemedtsson et al., 2005; Mäkiranta et al., 2007). A low $C / N$ ratio evidently favors net nitrogen mineralization and associated nitrification serving nitrate for denitrification. The annual mean ( \pm standard deviation) $\mathrm{N}_{2} \mathrm{O}$ emission from forestry drained ombrotrophic peatlands is lower, $0.01 \pm 0.01 \mathrm{~g} \mathrm{~m}^{-2}(n=11)$, than that in minerotrophic sites $0.45 \pm 0.79 \mathrm{~g} \mathrm{~m}^{-2}(n=31)$. There are only few measured winter data from boreal peatland forests. According to recent results these winter emissions can be high, up to $3 \mathrm{~g} \mathrm{~m}^{-2}$. They may even account for $80 \%$ of the annual emissions, resulting in a severe underestimation of annual values for nutrient rich forested peatlands (Maljanen et al., 2010a), if they are not included in the annual estimates.

Drainage of peatlands for forestry changes the microbial processes in soils and the associated greenhouse gas fluxes. However, the ditches can have different gas dynamics than the strips. Even though the strips show $\mathrm{CH}_{4}$ uptake, the ditches can still emit $\mathrm{CH}_{4}$ as shown in a Finnish 
Table 2. Annual balances of $\mathrm{CH}_{4}\left(\mathrm{~g} \mathrm{~m}^{-2} \mathrm{yr}^{-1}\right), \mathrm{N}_{2} \mathrm{O}\left(\mathrm{g} \mathrm{m}^{-2} \mathrm{yr}^{-1}\right)$ and net ecosystem $\mathrm{CO}_{2}$ exchange $\left(\mathrm{g} \mathrm{m}^{-2} \mathrm{yr}^{-1}, R=\mathrm{only} \mathrm{forest}\right.$ floor respiration) from forestry drained peatlands and restored (REF) forested sites in the Nordic countries $(\mathrm{DK}=\mathrm{Denmark}, \mathrm{FI}=\mathrm{Finland}$, $\mathrm{SE}=$ Sweden). Peatland types are $\mathrm{Om}=$ ombrotrophic peatland or $\mathrm{Mi}=$ minerotrophic peatland. Tree species were spruce $(\mathrm{SP})$, beech $(\mathrm{BE})$, alder (AL), pine (PI) or birch (BI). A negative value indicates uptake, a positive value indicates emission. Methods are $\mathrm{CH}=$ chamber, $\mathrm{GC}=$ gas chromatograph, $\mathrm{IR}=$ infra-red analyzer and $\mathrm{EC}=$ Eddy covariance method. If annual emission is estimated based on seasonal results the original measuring period (months from-to) is shown in column "Per." and the original emission value for that period in brackets.

\begin{tabular}{|c|c|c|c|c|c|c|c|c|c|c|}
\hline Type,trees & Method & & Location & $\mathrm{C}: \mathrm{N}$ & $\mathrm{pH}$ & $\mathrm{CH}_{4}$ & $\mathrm{~N}_{2} \mathrm{O}$ & $\mathrm{CO}_{2}$ & Per. & Ref. \\
\hline $\mathrm{Mi}, \mathrm{SP}$ & $\mathrm{CH}+\mathrm{GC}$ & FI & $60^{\circ} 21^{\prime} \mathrm{N}, 25^{\circ} 03^{\prime} \mathrm{E}$ & ND & ND & $-0.14(-0.12)$ & $0.02(0.01)$ & ND & $6-10$ & $\mathrm{a}$ \\
\hline $\mathrm{Mi}, \mathrm{SP}$ & $\mathrm{CH}+\mathrm{GC}$ & FI & $61^{\circ} 23^{\prime} \mathrm{N}, 25^{\circ} 03^{\prime} \mathrm{E}$ & ND & ND & $-0.11(-0.11)$ & $0.08(0.04)$ & ND & $6-10$ & $\mathrm{a}$ \\
\hline $\mathrm{Mi}$ & $\mathrm{CH}+\mathrm{GC}$ & FI & $61^{\circ} 47^{\prime} \mathrm{N}, 24^{\circ} 18^{\prime} \mathrm{E}$ & ND & 3.7 & 3.03 & ND & ND & & $\mathrm{b}$ \\
\hline Mi & $\mathrm{CH}+\mathrm{GC}$ & FI & $61^{\circ} 47^{\prime} \mathrm{N}, 24^{\circ} 18^{\prime} \mathrm{E}$ & ND & 3.8 & 2.69 & ND & ND & & $\mathrm{b}$ \\
\hline Mi & $\mathrm{CH}+\mathrm{GC}$ & FI & $61^{\circ} 47^{\prime} \mathrm{N}, 24^{\circ} 18^{\prime} \mathrm{E}$ & ND & 3.8 & 3.47 & ND & ND & & $\mathrm{b}$ \\
\hline Mi & $\mathrm{CH}+\mathrm{GC}$ & FI & $62^{\circ} 46^{\prime} \mathrm{N}, 29^{\circ} 50^{\prime} \mathrm{E}$ & ND & 3.8 & 0.99 & ND & ND & & $\mathrm{b}$ \\
\hline Mi & $\mathrm{CH}+\mathrm{GC}$ & FI & $61^{\circ} 47^{\prime} \mathrm{N}, 24^{\circ} 18^{\prime} \mathrm{E}$ & ND & 4.3 & 1.1 & ND & ND & & $\mathrm{b}$ \\
\hline Mi & $\mathrm{CH}+\mathrm{GC}$ & FI & $62^{\circ} 51^{\prime} \mathrm{N}, 30^{\circ} 53^{\prime} \mathrm{E}$ & ND & ND & -0.87 & ND & ND & & $\mathrm{c}$ \\
\hline Mi & $\mathrm{CH}+\mathrm{GC}$ & FI & $61^{\circ} 47^{\prime} \mathrm{N}, 24^{\circ} 19^{\prime} \mathrm{E}$ & ND & ND & 0.05 & 0.15 & $1320^{R}$ & & $\mathrm{~d}$ \\
\hline $\mathrm{Mi}$ & $\mathrm{CH}+\mathrm{GC}$ & FI & $61^{\circ} 48^{\prime} \mathrm{N}, 24^{\circ} 17^{\prime} \mathrm{E}$ & ND & ND & 0.1 & ND & ND & & $\mathrm{e}$ \\
\hline $\mathrm{Mi}$ & $\mathrm{CH}+\mathrm{GC}$ & FI & $61^{\circ} 48^{\prime} \mathrm{N}, 24^{\circ} 19^{\prime} \mathrm{E}$ & ND & ND & $<0.01$ & ND & ND & & $\mathrm{f}$ \\
\hline $\mathrm{Mi}, \mathrm{PI}$ & $\mathrm{EC}$ & FI & $60^{\circ} 43^{\prime} \mathrm{N}, 24^{\circ} 27^{\prime} \mathrm{E}$ & ND & ND & ND & 0.10 & -900 & & $\mathrm{~g}$ \\
\hline $\mathrm{Mi}$ & $\mathrm{CH}+\mathrm{GC}$ & FI & $61^{\circ} 47^{\prime} \mathrm{N}, 24^{\circ} 18^{\prime} \mathrm{E}$ & ND & ND & $-0.03(-0.02)$ & ND & ND & $5-11$ & $\mathrm{~h}$ \\
\hline $\mathrm{Mi}, \mathrm{PI}$ & $\mathrm{CH}+\mathrm{GC}$ & FI & $62^{\circ} 51^{\prime} \mathrm{N}, 30^{\circ} 53^{\prime} \mathrm{E}$ & ND & 4.3 & ND & 0.21 & ND & & $\mathrm{i}$ \\
\hline Mi, BI & $\mathrm{CH}+\mathrm{GC}$ & FI & $61^{\circ} 47^{\prime} \mathrm{N}, 24^{\circ} 18^{\prime} \mathrm{E}$ & ND & 4.6 & ND & 0.10 & ND & & $\mathrm{i}$ \\
\hline Mi, PI & $\mathrm{CH}+\mathrm{GC}$ & FI & $61^{\circ} 47^{\prime} \mathrm{N}, 24^{\circ} 18^{\prime} \mathrm{E}$ & ND & 4.6 & ND & 0.15 & ND & & $\mathrm{i}$ \\
\hline Mi, BIPI & $\mathrm{CH}+\mathrm{GC}$ & FI & $63^{\circ} 55^{\prime} \mathrm{N}, 23^{\circ} 58^{\prime} \mathrm{E}$ & 21 & 3.7 & -0.20 & 4.10 & $2600^{R}$ & & j \\
\hline Mi, BI & $\mathrm{CH}+\mathrm{GC}$ & FI & $62^{\circ} 31^{\prime} \mathrm{N}, 29^{\circ} 23^{\prime} \mathrm{E}$ & 20 & 4.5 & -0.39 & 0.66 & ND & & $\mathrm{k}$ \\
\hline Mi, PI & $\mathrm{CH}+\mathrm{GC}$ & FI & $64^{\circ} 51^{\prime} \mathrm{N}, 26^{\circ} 33^{\prime} \mathrm{E}$ & ND & 3.7 & $-0.50(-0.23)$ & $0.97(0.32)$ & ND & $6-8$ & 1 \\
\hline $\mathrm{Mi}$ & $\mathrm{CH}+\mathrm{GC}$ & FI & $64^{\circ} 88^{\prime} \mathrm{N}, 26^{\circ} 13^{\prime} \mathrm{E}$ & ND & 3.5 & $0.99(0.43)$ & $0.01(0.004)$ & ND & $6-8$ & 1 \\
\hline Mi & $\mathrm{CH}+\mathrm{GC}$ & FI & $64^{\circ} 86^{\prime} \mathrm{N}, 26^{\circ} 11^{\prime} \mathrm{E}$ & ND & 4.1 & $0.10(0.05)$ & $0.02(0.01)$ & ND & $6-8$ & 1 \\
\hline $\mathrm{Mi}$ & $\mathrm{CH}+\mathrm{GC}$ & FI & $64^{\circ} 85^{\prime} \mathrm{N}, 26^{\circ} 07^{\prime} \mathrm{E}$ & ND & 3.9 & $4.97(2.16)$ & $0.19(0.06)$ & ND & $6-8$ & 1 \\
\hline $\mathrm{Mi}, \mathrm{PI}$ & $\mathrm{CH}+\mathrm{IR}$ & FI & $58^{\circ} 59^{\prime} \mathrm{N}, 25^{\circ} 27^{\prime} \mathrm{E}$ & ND & ND & ND & ND & $1380^{R}$ & & $\mathrm{~m}$ \\
\hline $\mathrm{Mi}, \mathrm{PI}$ & $\mathrm{CH}+\mathrm{IR}$ & FI & $61^{\circ} 22^{\prime} \mathrm{N}, 25^{\circ} 07^{\prime} \mathrm{E}$ & ND & ND & ND & ND & $909^{R}$ & & $\mathrm{~m}$ \\
\hline $\mathrm{Mi}, \mathrm{PI}$ & $\mathrm{CH}+\mathrm{IR}$ & FI & $66^{\circ} 21^{\prime} \mathrm{N}, 26^{\circ} 37^{\prime} \mathrm{E}$ & ND & ND & ND & ND & $1890^{R}$ & & $\mathrm{~m}$ \\
\hline $\mathrm{Mi}$ & $\mathrm{CH}+\mathrm{GC}$ & FI & $60^{\circ} 39^{\prime} \mathrm{N}, 24^{\circ} 22^{\prime} \mathrm{E}$ & ND & ND & -0.30 & ND & ND & & $\mathrm{m}$ \\
\hline $\mathrm{Mi}, \mathrm{SP}$ & $\mathrm{CH}+\mathrm{GC}$ & FI & $61^{\circ} 22^{\prime} \mathrm{N}, 25^{\circ} 07^{\prime} \mathrm{E}$ & ND & ND & -0.69 & ND & ND & & $\mathrm{m}$ \\
\hline $\mathrm{Mi}, \mathrm{BI}$ & $\mathrm{CH}+\mathrm{GC}$ & FI & $61^{\circ} 24^{\prime} \mathrm{N}, 25^{\circ} 02^{\prime} \mathrm{E}$ & ND & ND & -0.44 & ND & ND & & $\mathrm{m}$ \\
\hline $\mathrm{Mi}$ & $\mathrm{CH}+\mathrm{GC}$ & FI & $66^{\circ} 21^{\prime} \mathrm{N}, 26^{\circ} 37^{\prime} \mathrm{E}$ & ND & ND & -0.03 & ND & ND & & $\mathrm{m}$ \\
\hline Mi & $\mathrm{CH}+\mathrm{GC}$ & FI & $66^{\circ} 28^{\prime} \mathrm{N}, 25^{\circ} 51^{\prime} \mathrm{E}$ & ND & ND & 0.65 & ND & ND & & $\mathrm{m}$ \\
\hline Mi & $\mathrm{CH}+\mathrm{GC}$ & FI & $61^{\circ} 47^{\prime} \mathrm{N}, 21^{\circ} 18^{\prime} \mathrm{E}$ & ND & 4.6 & ND & $0.16(0.11)$ & ND & $5-12$ & $\mathrm{n}$ \\
\hline $\mathrm{Mi}, \mathrm{PI}$ & $\mathrm{CH}+\mathrm{GC}$ & FI & $61^{\circ} 47^{\prime} \mathrm{N}, 21^{\circ} 18^{\prime} \mathrm{E}$ & ND & 4.0 & ND & $0.05(0.04)$ & ND & $5-12$ & $\mathrm{n}$ \\
\hline Mi, PIBI & $\mathrm{CH}+\mathrm{GC}$ & FI & $62^{\circ} 46^{\prime} \mathrm{N}, 30^{\circ} 58^{\prime} \mathrm{E}$ & ND & 4.5 & ND & $0.22(0.15)$ & ND & $5-12$ & $\mathrm{n}$ \\
\hline $\mathrm{Mi}$ & $\mathrm{CH}+\mathrm{GC}$ & FI & $62^{\circ} 46^{\prime} \mathrm{N}, 30^{\circ} 58^{\prime} \mathrm{E}$ & ND & ND & ND & $0(<0.01)$ & ND & $5-12$ & $\mathrm{n}$ \\
\hline Mi, BIPISP & $\mathrm{CH}+\mathrm{GC}$ & FI & $62^{\circ} 46^{\prime} \mathrm{N}, 30^{\circ} 58^{\prime} \mathrm{E}$ & ND & 4.5 & ND & 0.82 & ND & & o \\
\hline Mi, BIPISP ${ }^{2}$ & $\mathrm{CH}+\mathrm{GC}$ & FI & $62^{\circ} 46^{\prime} \mathrm{N}, 30^{\circ} 58^{\prime} \mathrm{E}$ & ND & 4.5 & ND & 0.93 & ND & & o \\
\hline Mi, BIPISP ${ }^{3}$ & $\mathrm{CH}+\mathrm{GC}$ & FI & $62^{\circ} 46^{\prime} \mathrm{N}, 30^{\circ} 58^{\prime} \mathrm{E}$ & ND & 4.3 & ND & 1.5 & ND & & o \\
\hline Mi, BIPISP 4 & $\mathrm{CH}+\mathrm{GC}$ & FI & $62^{\circ} 46^{\prime} \mathrm{N}, 30^{\circ} 58^{\prime} \mathrm{E}$ & ND & 4.5 & ND & 1.2 & ND & & o \\
\hline $\mathrm{Mi}, \mathrm{BE}$ & $\mathrm{CH}+\mathrm{GC}$ & DK & $55^{\circ} 31^{\prime} \mathrm{N}, 11^{\circ} 46^{\prime} \mathrm{E}$ & ND & 6.8 & ND & 0.10 & ND & & $\mathrm{p}$ \\
\hline $\mathrm{Mi}, \mathrm{BE}$ & $\mathrm{CH}+\mathrm{GC}$ & DK & $55^{\circ} 15^{\prime} \mathrm{N}, 14^{\circ} 45^{\prime} \mathrm{E}$ & ND & 5.4 & ND & 0.30 & ND & & $\mathrm{p}$ \\
\hline $\mathrm{Mi}, \mathrm{BE}$ & $\mathrm{CH}+\mathrm{GC}$ & $\mathrm{DK}$ & $55^{\circ} 15^{\prime} \mathrm{N}, 11^{\circ} 55^{\prime} \mathrm{E}$ & ND & 5.2 & ND & 0.14 & ND & & $\mathrm{p}$ \\
\hline $\mathrm{Mi}, \mathrm{BE}$ & $\mathrm{CH}+\mathrm{GC}$ & DK & $55^{\circ} 57^{\prime} \mathrm{N}, 12^{\circ} 17^{\prime} \mathrm{E}$ & ND & 4.4 & ND & 0.15 & ND & & $\mathrm{p}$ \\
\hline $\mathrm{Mi}, \mathrm{SP}_{\text {young }}$ & $\mathrm{CH}+\mathrm{GC}$ & SE & $57^{\circ} 08^{\prime} \mathrm{N}, 14^{\circ} 45^{\prime} \mathrm{E}$ & 26 & 3.3 & 0.03 & 0.08 & $1430^{R}$ & & $\mathrm{q}$ \\
\hline $\mathrm{Mi}, \mathrm{SP}_{\mathrm{old}}$ & $\mathrm{CH}+\mathrm{GC}$ & SE & $57^{\circ} 08^{\prime} \mathrm{N}, 14^{\circ} 45^{\prime} \mathrm{E}$ & 28 & 3.2 & 0.30 & 0.05 & $3800^{R}$ & & $\mathrm{q}$ \\
\hline $\mathrm{Mi}, \mathrm{PI}$ & $\mathrm{CH}+\mathrm{GC}$ & $\mathrm{SE}$ & $57^{\circ} 08^{\prime} \mathrm{N}, 14^{\circ} 45^{\prime} \mathrm{E}$ & 40 & 2.7 & 1.07 & 0.04 & $1470^{R}$ & & $\mathrm{q}$ \\
\hline $\mathrm{Mi}, \mathrm{BI}$ & $\mathrm{CH}+\mathrm{GC}$ & SE & $57^{\circ} 08^{\prime} \mathrm{N}, 14^{\circ} 45^{\prime} \mathrm{E}$ & 22 & 3.4 & 0.9 & 0.20 & $1900^{R}$ & & $\mathrm{r}$ \\
\hline $\mathrm{Mi}, \mathrm{AL}$ & $\mathrm{CH}+\mathrm{GC}$ & SE & $57^{\circ} 08^{\prime} \mathrm{N}, 14^{\circ} 45^{\prime} \mathrm{E}$ & 16 & 4.5 & 0.9 & 0.90 & $1700^{R}$ & & $\mathrm{r}$ \\
\hline $\mathrm{Mi}, \mathrm{SP}^{1}$ & $\mathrm{CH}+\mathrm{GC}$ & FI & $60^{\circ} 21^{\prime} \mathrm{N}, 25^{\circ} 03^{\prime} \mathrm{E}$ & ND & ND & $-0.01(-0.01)$ & $0.26(0.17)$ & ND & $6-10$ & $\mathrm{a}$ \\
\hline $\mathrm{Mi}, \mathrm{SP}^{1}$ & $\mathrm{CH}+\mathrm{GC}$ & FI & $61^{\circ} 23^{\prime} \mathrm{N}, 25^{\circ} 03^{\prime} \mathrm{E}$ & ND & ND & $-0.10(-0.09)$ & $0.07(0.04)$ & ND & $6-10$ & $\mathrm{a}$ \\
\hline Mi SPPI ${ }^{1}$ & $\mathrm{CH}+\mathrm{GC}$ & FI & $63^{\circ} 39^{\prime} \mathrm{N}, 29^{\circ} 29^{\prime} \mathrm{E}$ & ND & 5.3 & 0.08 & 0.02 & ND & & $\mathrm{s}$ \\
\hline
\end{tabular}


Table 2. Continued.

\begin{tabular}{|c|c|c|c|c|c|c|c|c|c|c|}
\hline Type,trees & Method & & Location & $\mathrm{C}: \mathrm{N}$ & $\mathrm{pH}$ & $\mathrm{CH}_{4}$ & $\mathrm{~N}_{2} \mathrm{O}$ & $\mathrm{CO}_{2}$ & Per. & Ref. \\
\hline Mi SP & $\mathrm{CH}+\mathrm{GC}$ & SE & $58^{\circ} 23^{\prime} \mathrm{N}, 12^{\circ} 09^{\prime} \mathrm{E}$ & 23 & 4.5 & -0.45 & 0.41 & ND & & $\mathrm{t}$ \\
\hline Om, PI & $\mathrm{CH}+\mathrm{GC}$ & SE & $57^{\circ} 15^{\prime} \mathrm{N}, 13^{\circ} 35^{\prime} \mathrm{E}$ & 34 & 4.9 & 0.89 & $<0.01$ & ND & & $\mathrm{t}$ \\
\hline Om, PI & $\mathrm{CH}+\mathrm{GC}$ & FI & $61^{\circ} 47^{\prime} \mathrm{N}, 24^{\circ} 18^{\prime} \mathrm{E}$ & ND & 4.1 & ND & $<0.01$ & ND & & $\mathrm{i}$ \\
\hline Om, PI & $\mathrm{CH}+\mathrm{GC}$ & FI & $61^{\circ} 47^{\prime} \mathrm{N}, 24^{\circ} 18^{\prime} \mathrm{E}$ & ND & 4.0 & ND & $<0.01$ & ND & & $\mathrm{i}$ \\
\hline Om & $\mathrm{CH}+\mathrm{GC}$ & FI & $61^{\circ} 47^{\prime} \mathrm{N}, 24^{\circ} 19^{\prime} \mathrm{E}$ & ND & ND & 4.33 & $<0.02$ & $880^{R}$ & & $\mathrm{~d}$ \\
\hline $\mathrm{Om}$ & $\mathrm{CH}+\mathrm{GC}$ & FI & $61^{\circ} 47^{\prime} \mathrm{N}, 24^{\circ} 18^{\prime} \mathrm{E}$ & ND & ND & $3.73(3.24)$ & ND & ND & $5-11$ & $\mathrm{~h}$ \\
\hline $\mathrm{Om}$ & $\mathrm{CH}+\mathrm{GC}$ & FI & $61^{\circ} 51^{\prime} \mathrm{N}, 24^{\circ} 14^{\prime} \mathrm{E}$ & ND & ND & 0.7 & ND & ND & & e \\
\hline $\mathrm{Om}$ & $\mathrm{CH}+\mathrm{GC}$ & FI & $61^{\circ} 47^{\prime} \mathrm{N}, 24^{\circ} 18^{\prime} \mathrm{E}$ & ND & 3.8 & -0.02 & ND & ND & & $\mathrm{b}$ \\
\hline Om & $\mathrm{CH}+\mathrm{GC}$ & FI & $62^{\circ} 46^{\prime} \mathrm{N}, 29^{\circ} 50^{\prime} \mathrm{E}$ & ND & 4.0 & 0.12 & ND & ND & & $\mathrm{b}$ \\
\hline $\mathrm{Om}$ & $\mathrm{CH}+\mathrm{GC}$ & FI & $62^{\circ} 46^{\prime} \mathrm{N}, 29^{\circ} 50^{\prime} \mathrm{E}$ & ND & 4.5 & -0.14 & ND & ND & & $\mathrm{b}$ \\
\hline $\mathrm{Om}$ & $\mathrm{CH}+\mathrm{GC}$ & FI & $62^{\circ} 46^{\prime} \mathrm{N}, 29^{\circ} 50^{\prime} \mathrm{E}$ & ND & ND & 0.87 & ND & ND & & $\mathrm{b}$ \\
\hline Om & $\mathrm{CH}+\mathrm{GC}$ & FI & $64^{\circ} 49^{\prime} \mathrm{N}, 26^{\circ} 26^{\prime} \mathrm{E}$ & ND & 4.3 & $0.50(0.22)$ & $0.03(0.01)$ & ND & $6-8$ & 1 \\
\hline Om, PI & $\mathrm{CH}+\mathrm{GC}$ & FI & $61^{\circ} 47^{\prime} \mathrm{N}, 21^{\circ} 18^{\prime} \mathrm{E}$ & ND & 3.8 & ND & $0.01(0.01)$ & ND & $5-12$ & $\mathrm{n}$ \\
\hline Om, PI & $\mathrm{CH}+\mathrm{GC}$ & FI & $61^{\circ} 47^{\prime} \mathrm{N}, 21^{\circ} 18^{\prime} \mathrm{E}$ & ND & 4.1 & ND & $0.002(0.001)$ & ND & $5-12$ & $\mathrm{n}$ \\
\hline Om, PI & $\mathrm{CH}+\mathrm{GC}$ & FI & $61^{\circ} 47^{\prime} \mathrm{N}, 21^{\circ} 18^{\prime} \mathrm{E}$ & ND & 3.8 & ND & $0.01(0.01)$ & ND & $5-12$ & $\mathrm{n}$ \\
\hline Om, PI & $\mathrm{CH}+\mathrm{GC}$ & FI & $61^{\circ} 47^{\prime} \mathrm{N}, 21^{\circ} 18^{\prime} \mathrm{E}$ & ND & 4.3 & ND & $0.01(0.01)$ & ND & $5-12$ & $\mathrm{n}$ \\
\hline $\mathrm{Om}$ & $\mathrm{CH}+\mathrm{GC}$ & FI & $61^{\circ} 47^{\prime} \mathrm{N}, 21^{\circ} 18^{\prime} \mathrm{E}$ & ND & 4.0 & ND & $0.004(0.003)$ & ND & $5-12$ & $\mathrm{n}$ \\
\hline Om, PI & $\mathrm{CH}+\mathrm{GC}$ & FI & $61^{\circ} 47^{\prime} \mathrm{N}, 21^{\circ} 18^{\prime} \mathrm{E}$ & ND & ND & ND & $0(<0.01)$ & ND & $5-12$ & $\mathrm{n}$ \\
\hline REF, Mi & $\mathrm{CH}+\mathrm{IR}$ & FI & $61^{\circ} 48^{\prime} \mathrm{N}, 24^{\circ} 17^{\prime} \mathrm{E}$ & 29 & ND & ND & ND & -705 & & $\mathrm{u}$ \\
\hline REF, Mi & $\mathrm{CH}+\mathrm{GC}$ & FI & $61^{\circ} 48^{\prime} \mathrm{N}, 24^{\circ} 17^{\prime} \mathrm{E}$ & ND & 4.3 & ND & 0.55 & ND & & $\mathrm{v}$ \\
\hline $\mathrm{REF}, \mathrm{Mi}^{5}$ & $\mathrm{CH}+\mathrm{GC}$ & FI & $61^{\circ} 48^{\prime} \mathrm{N}, 24^{\circ} 17^{\prime} \mathrm{E}$ & ND & 4.3 & ND & 2.0 & ND & & $\mathrm{v}$ \\
\hline REF, Mi & $\mathrm{CH}+\mathrm{GC}$ & FI & $61^{\circ} 48^{\prime} \mathrm{N}, 24^{\circ} 17^{\prime} \mathrm{E}$ & 29 & ND & 2.1 & ND & ND & & $\mathrm{e}$ \\
\hline REF, Om & $\mathrm{CH}+\mathrm{GC}$ & FI & $61^{\circ} 51^{\prime} \mathrm{N}, 24^{\circ} 14^{\prime} \mathrm{E}$ & 42 & ND & 4.6 & ND & ND & & e \\
\hline REF, Om & $\mathrm{CH}+\mathrm{IR}$ & FI & $61^{\circ} 51^{\prime} \mathrm{N}, 24^{\circ} 14^{\prime} \mathrm{E}$ & 42 & ND & ND & ND & -174 & & $\mathrm{u}$ \\
\hline
\end{tabular}

1 after clear-cutting, ${ }^{2} \mathrm{KNO}_{3}$ fertilization, ${ }^{3} \mathrm{NH}_{4} \mathrm{Cl}$ fertilization, ${ }^{4}$ urea fertilization, ${ }^{5} \mathrm{NO}_{3}^{-}$fertilization,

(a) Huttunen et al. (2003); (b) Nykänen et al. (1998); (c) Martikainen et al. (1995b); (d) Martikainen et al. (1995a); (e) Komulainen et al. (1998); (f) Laine et al. (1996); (g) Laurila et al. (2007); (h) Martikainen et al. (1992); (i) Martikainen et al. (1993); (j) Maljanen et 1. (2010a); (k) Maljanen et al. (2003a,b); (l) Maljanen et al. (2006a); (m) Minkkinen et al. (2007); (n) Regina et al. (1996); (o) Regina et al. (1998); (p) Struwe and Kjøller (1994); (q) Von Arnold et al. (2005b); (r) Von Arnold et al. (2005c); (s) Saari et al. (2009a); (t) Sikström et al. (2009); (u) Komulainen et al. (1999); (v) Silvan et al. (2002, 2005)

study (Minkkinen et al., 1997). Minkkinen et al. (1997) estimated that the $\mathrm{CH}_{4}$ emission from ditches was $4.5 \%$ of the total $\mathrm{CH}_{4}$ emissions from peatland drained for forestry during summer. Ditches would also affect the $\mathrm{N}_{2} \mathrm{O}$ release from drained peatlands. GHG emissions associated with ditches include not only the direct emissions but also transport in the ditch water. There is no data on the importance of the later aspect.

The net annual $\mathrm{CO}_{2}$ exchange measured with the EC method has been reported in Finland only for one minerotrophic site with Scots pine (Pinus sylvestris) stand. This site has an annual balance of $-900 \mathrm{~g} \mathrm{CO}_{2} \mathrm{~m}^{-2}$ (Laurila et al., 2007). Klemedtsson et al. (2007) measured and modeled annual $\mathrm{CO}_{2}$ exchange rates for a forested peatland in Sweden (540-1100 $\mathrm{g} \mathrm{CO}_{2} \mathrm{~m}^{-2}$ ). Pihlatie et al. (2009) measured $\mathrm{CO}_{2}$ exchange above a canopy in a drained peatland from April to June and the growing season net $\mathrm{CO}_{2}$ exchange rate was $-800 \mathrm{~g} \mathrm{~m}^{-2}$. The annual $\mathrm{CO}_{2}$ uptake in a forested peatland in Scotland has been higher than that in the Finnish and Swedish studies, the net $\mathrm{CO}_{2}$ exchange being $-1830 \mathrm{~g} \mathrm{~m}^{-2}$ (Hargreaves et al., 2003).
The net $\mathrm{CO}_{2}$ ecosystem exchange (NEE) in forestry drained peatland is highly dependent on the age of the tree stand as well as the weather conditions. The site fertility probably has an impact on $\mathrm{CO}_{2}$ balance, but the existing data based on the EC measurements are too limited to conclude on the importance of fertility in the $\mathrm{CO}_{2}$ balance. An important open question is the fate of soil carbon in forested peatlands. There is an evidence that the storage of soil carbon in peatland forests varies in peatlands with different fertility (e.g. Minkkinen and Laine, 1998). Hargreaves et al. (2003) reported that during the early years after drainage, peat soils in Scotland were sources of $\mathrm{CO}_{2}$, however, they turned into $\mathrm{CO}_{2}$ sinks after 4 to 8 years from planting of trees.

To estimate the impact of forestry drainage on the GHG balances the whole stand rotation has to be included (Minkkinen et al., 2001). There is little information on how the carbon balance or $\mathrm{N}_{2} \mathrm{O}$ fluxes are affected by clear cutting and what is the balance during the second rotation period. Clear cutting changes e.g. stand density and site hydrology and thus also the oxygen status of the soil which in turn affects the decomposition rate of organic matter and emissions of $\mathrm{CO}_{2}, \mathrm{CH}_{4}$ and $\mathrm{N}_{2} \mathrm{O}$. The effect of clear cutting has been 
studied in two forested peatland sites in Finland. In the study by Saari et al. (2009a), peatland forest turned from a small $\mathrm{N}_{2} \mathrm{O}$ sink to a $\mathrm{N}_{2} \mathrm{O}$ source after clear cutting. In the study by Huttunen et al. (2003) $\mathrm{N}_{2} \mathrm{O}$ emissions increased and $\mathrm{CH}_{4}$ uptake rates decreased following clear cutting. No data exists on the net $\mathrm{CO}_{2}$ exchange after clear cutting and how soil preparation for the second rotation would change the $\mathrm{CO}_{2}$ dynamics.

Buffer zones are used in peatland forestry to remove $\mathrm{P}$ and $\mathrm{N}$ from the discharge. The sedimentation ponds in these areas with high $\mathrm{N}$ load can be potential hot spots for $\mathrm{N}_{2} \mathrm{O}$ emissions, up to $82 \mu \mathrm{g} \mathrm{m}^{-2} \mathrm{~h}^{-1}$ (Saari et al., 2009b). However, the areas covered by buffer zones are rather small and therefore are not significant GHG sources at a landscape level (Saari et al., 2009b).

The mean greenhouse gas flux rates of forested Nordic peatlands are compared with those measured in upland forests in Table 6. Data for net $\mathrm{CO}_{2}$ exchange is available from 16 upland forests; most of them are sinks for $\mathrm{CO}_{2}$. However, some forst sites have been sources of $\mathrm{CO}_{2}$ (Lindroth et al., 1998, 2007). One of these mineral soil sites with exceptionally high net $\mathrm{CO}_{2}$ emissions also had a high organic C content in the soil profile (Lindroth et al., 1998). In general, peatland forests emit more $\mathrm{N}_{2} \mathrm{O}$ than upland forests (Table 6). Peatland forests can be either source or sink for $\mathrm{CH}_{4}$ depending on the drainage status, but upland forests most often are sinks for atmospheric $\mathrm{CH}_{4}$ (Table 6).

\subsubsection{Peatlands drained for agriculture}

\section{Peat soils with annual or perennial crops}

GHG dynamics of peat soils used for agriculture are intensively studied in all Nordic countries; published data is available from Finland, Sweden and Norway. There is data on soils growing perennial grasses (16 sites), barley (6 sites) and for one site with potato and one with carrot. No data are available on GHG emissions directly from the drainage ditches of croplands in the Nordic countries.

$\mathrm{CH}_{4}$ and $\mathrm{N}_{2} \mathrm{O}$ fluxes are measured with chamber methods, net $\mathrm{CO}_{2}$ exchange with chambers at 10 sites and with $\mathrm{EC}$ methods at four sites (Table 3). The croplands have been divided into grass swards and croplands with cereals or potato. The grasslands studied in Finland have been non-permanent grasslands which are ploughed and re-sown at three to four year intervals. In addition to the actively cultivated peatlands, fallow soils without vegetation (Maljanen et al., 2003a,b, 2004; Regina et al., 2004), abandoned croplands in Finland and Norway (Maljanen et al., 2007a; Kløve et al., 2010) and drained but not ploughed sites used for grazing in Iceland (Table 3) have been studied.

The GHG emissions from peatlands used for agriculture can differ in magnitude resulting from differences in cultivation methods, crops and weather conditions. Peatlands used for crop cultivation are significant sources of
$\mathrm{CO}_{2}$ and $\mathrm{N}_{2} \mathrm{O}$. Depending on the WT level, croplands on peat soils are small sinks or sources of $\mathrm{CH}_{4}$. The average emissions ( \pm standard deviation) from peat soils with perennial grass swards is $0.32 \pm 0.64 \mathrm{~g} \mathrm{CH}_{4} \mathrm{~m}^{-2}(n=11)$, $1.50 \pm 1.60 \mathrm{~g} \mathrm{~N}_{2} \mathrm{O} \mathrm{m}^{-2}(n=12)$ and $1800 \pm 1180 \mathrm{~g} \mathrm{CO}_{2} \mathrm{~m}^{-2}$ $(n=4)$. The estimated mean $\mathrm{N}_{2} \mathrm{O}$ emission from hay fields in Iceland $\left(0.05 \mathrm{~g} \mathrm{~N}_{2} \mathrm{O} \mathrm{m}^{-2}\right)$ is not included in the mean value.

Regularly ploughed and fertilized cropland soils (cereals) have been larger sources of $\mathrm{CO}_{2}$ and $\mathrm{N}_{2} \mathrm{O}$ than grass leys but because of their better aeration they are larger sinks for atmospheric $\mathrm{CH}_{4}$ than the grass swards. Peat soils planted with barley were minor sinks for $\mathrm{CH}_{4},-0.03 \pm 0.18 \mathrm{~g} \mathrm{~m}^{-2}$ $(n=5)$, and emitted $1.71 \pm 0.51 \mathrm{~g} \mathrm{~N}_{2} \mathrm{O} \mathrm{m}^{-2} \quad(n=5)$ and $1770 \pm 1160 \mathrm{~g} \mathrm{CO}_{2} \mathrm{~m}^{-2}(n=3)$. Annual $\mathrm{N}_{2} \mathrm{O}$ emission a potato field has been estimated to be $1.57 \mathrm{~g} \mathrm{~m}^{-2}$ (Regina et al., 2004).

Peat fields used for agriculture have always shown a net loss of $\mathrm{CO}_{2}$ in contrast to croplands on mineral soils (Table 6) as a result of peat decomposition. Peat soils drained for agriculture also have higher $\mathrm{N}_{2} \mathrm{O}$ emissions than mineral soils (Table 6) because they have also large N-pool. Even without $\mathrm{N}$-fertilization they can emit very large amounts of $\mathrm{N}_{2} \mathrm{O}$ compared to mineral soils (Maljanen et al., 2010; Syväsalo et al., 2004). Some peat fields emit $\mathrm{CH}_{4}$ depending on the WT level, whereas the studied croplands on mineral soils have all been annually sinks for atmospheric $\mathrm{CH}_{4}$ (Table 6). In agricultural peat soils, $\mathrm{CO}_{2}$ is responsible for $80 \%$ of the total GWP and the rest is mostly from the $\mathrm{N}_{2} \mathrm{O}$ emissions. Methane makes a negligible contribution to the total GWP on these well drained soils.

\section{Fallow soils (agricultural soils without vegetation)}

Nitrous oxide emissions from fallow soils have been studied in five sites, $\mathrm{CH}_{4}$ fluxes in three sites and $\mathrm{CO}_{2}$ exchange in three sites in Finland. These sites have been kept clear from vegetation during one season with regular ploughing (Maljanen et al., 2001a; 2003a,b, 2004; Nykänen et al., 1995; Regina et al., 2004). In the absence of plants, some of these sites emit more $\mathrm{CO}_{2}$ and $\mathrm{N}_{2} \mathrm{O}$ than the vegetated sites. The mean $( \pm$ standard deviation $) \mathrm{N}_{2} \mathrm{O}$ and $\mathrm{CO}_{2}$ annual emissions from fallow sites, $2.13 \pm 1.62 \mathrm{~g} \mathrm{~N}_{2} \mathrm{O} \mathrm{m}^{-2}$ and $2507 \pm 968 \mathrm{CO}_{2} \mathrm{~m}^{-2}$, were slightly higher than those from soils cultivated with grass or cereals. These well drained fallow sites have been annually small sinks for $\mathrm{CH}_{4}$ $\left(-0.10 \pm 0.14 \mathrm{~g} \mathrm{CH}_{4} \mathrm{~m}^{-2}\right)$.

\section{Abandoned croplands}

In this review, we discuss annual exchange of $\mathrm{CH}_{4}, \mathrm{~N}_{2} \mathrm{O}$ and $\mathrm{CO}_{2}$ on abandoned croplands from five sites in Finland (Maljanen et al., 2007a) and from one site in Norway (Kløve et al., 2010). We could expect that when soil management activities for cultivation cease, e.g. ploughing and fertilization (known to enhance the rate of microbiological 
processes in peat), the emissions of $\mathrm{N}_{2} \mathrm{O}$ and $\mathrm{CO}_{2}$ would decrease. However, the annual $\mathrm{N}_{2} \mathrm{O}$ and $\mathrm{CO}_{2}$ emissions from abandoned croplands have been similar to the emissions from actively managed croplands. The mean annual emissions ( \pm standard deviation) from abandoned sites were $0.89 \pm 0.70 \mathrm{~g} \mathrm{~m}^{-2}(n=6)$ for $\mathrm{N}_{2} \mathrm{O}$ and $1300 \pm 1100 \mathrm{~g} \mathrm{~m}^{-2}$ $(n=5)$ for $\mathrm{CO}_{2}$. The abandoned sites were annually small sinks for methane, $-0.01 \pm 0.28 \mathrm{~g} \mathrm{CH}_{4} \mathrm{~m}^{-2}(n=6)$. Some GHG measurements have also been performed on drained, abandoned sites in Iceland (J. Guðmundsson, Agricultural University of Iceland, personal communication, 2009). Because these sites are drained but never ploughed, they have a different history compared to the abandoned cropland sites in Finland. The estimated average annual $\mathrm{N}_{2} \mathrm{O}$ emission from the abandoned sites in Iceland $0.03 \pm 0.02 \mathrm{~g} \mathrm{~N}_{2} \mathrm{O} \mathrm{m}^{-2}(n=3)$ is lower than that from ploughed and fertilized soils in Finland.

\section{Afforested croplands}

Methane and $\mathrm{N}_{2} \mathrm{O}$ balances of afforested agricultural soils have been studied intensively (Table 3). Annual $\mathrm{CH}_{4}$ and $\mathrm{N}_{2} \mathrm{O}$ fluxes measured from the forest floor of afforested croplands with static chambers have been reported for 10 different sites in Finland (Mäkiranta et al., 2007; Maljanen et al., 2001b) and two sites in Sweden (von Arnold et al., 2005c; Weslien et al., 2009). However, the annual net $\mathrm{CO}_{2}$ exchange (EC method), including the canopy, has been reported only for one site in Finland (Lohila et al., 2007).

It is expected that the afforestation of organic croplands reduces the GHG emissions. However, in most cases this is not true for the $\mathrm{N}_{2} \mathrm{O}$ emissions. The mean annual emission, $1.48 \pm 1.31 \mathrm{~g} \mathrm{~N}_{2} \mathrm{O} \mathrm{m}^{-2}(n=13)$, is similar to that for cultivated croplands on peatlands (from 1.2 to $1.7 \mathrm{~g} \mathrm{~N}_{2} \mathrm{O} \mathrm{m}^{-2}$ ). Depending on the WT level, the afforested sites act as either small sources or sinks for $\mathrm{CH}_{4}$. The mean annual $\mathrm{CH}_{4}$ emission is $0.23 \pm 0.69 \mathrm{~g} \mathrm{~m}^{-2}(n=12)$. The data on the net $\mathrm{CO}_{2}$ exchange (including trees) after afforestation of agricultural peatlands is limited to one site in Finland (Lohila et al., 2007). This site had an annual loss of $50 \mathrm{~g} \mathrm{CO}_{2} \mathrm{~m}^{-2}$ which is lower than the $\mathrm{CO}_{2}$ loss from cultivated croplands. Afforestation of organic croplands would thus reduce $\mathrm{CO}_{2}$ emissions, but $\mathrm{N}_{2} \mathrm{O}$ emissions may remain high. However, drained peat soils can act annually either as sinks or sources of $\mathrm{CO}_{2}$, since net $\mathrm{CO}_{2}$ exchange depends strongly on the climatic conditions including temperature and precipitation (e.g. Shurpali et al., 2009).

\subsubsection{Peatlands drained for peat extraction}

\section{Peatlands under active peat extraction}

Peat extraction for energy purposes is carried out in Finland and Sweden. Both pristine and forestry-drained peatlands have been used for peat extraction. Traditionally, the peat extraction sites are drained and the vegetation cover removed before the extraction. The draining phase lasts from one to five years before extraction. Peat extraction on these open areas is carried out for several years depending on the peat depth. A new method called "biomass dryer" has recently been developed for peat extraction. According to this method, the peat is extracted without any drainage phase of the site and the extracted moist peat is dried outside the extraction site on an asphalted field (VAPO, 2009). The GHG fluxes associated with this method are at present under study.

GHG emissions have been measured with chamber methods from the "traditional" peat extraction in Finland and Sweden (Table 4). Drained peat extraction sites are always sources of $\mathrm{CO}_{2}$ as a result of WT draw down and removal of vegetation. The sites are also sources for $\mathrm{N}_{2} \mathrm{O}$ and $\mathrm{CH}_{4}$. The annual emissions have been measured in five studies (Alm et al., 2007; Shurpali et al., 2008; Hyvönen et al., 2009; Nykänen et al., 1996; Tuittila et al., 2000). The annual emissions for other sites were calculated from the growing season values as described earlier. The mean annual emissions from peat extraction sites, excluding the emissions from ditches, are $1.65 \pm 2.42 \mathrm{~g} \mathrm{CH}_{4} \mathrm{~m}^{-2}(n=13), 0.09 \pm 0.11 \mathrm{~g} \mathrm{~N}_{2} \mathrm{O} \mathrm{m}^{-2}$ $(n=6)$ and $697 \pm 263 \mathrm{~g} \mathrm{~m}^{-2}$ for $\mathrm{CO}_{2}(n=12)$.

The net $\mathrm{CO}_{2}$ exchange from peat extraction areas (bare peat) depend e.g. on the quality of the peat and the time since drainage, as well as the climate (Nykänen et al., 1996; Waddington et al., 2002). Waddington et al. (2002) reported higher seasonal (from May to August) $\mathrm{CO}_{2}$ emissions for a dry year (1300 to $1500 \mathrm{~g} \mathrm{CO}_{2}$ ) than for a wet year (320 to $430 \mathrm{~g} \mathrm{CO}_{2}$ ) from peat extraction sites in Canada, Québeck. Emissions were slightly higher from the sites seven to eight years after peat extraction than from the sites from two to three years after peat extraction (Waddington et al., 2002).

The drainage ditches contribute to $\mathrm{CH}_{4}$ emissions from peat extraction sites. Methane emissions from drainage ditches have been measured in Sweden (Sundh et al., 2000) and Finland (Nykänen et al., 1996). The annual emissions from ditches varied from 0.3 to $140 \mathrm{~g} \mathrm{CH}_{4} \mathrm{~m}^{-2} \mathrm{yr}^{-1}$ (Nykänen et al., 1996; Sundh et al., 2000), thus $\mathrm{CH}_{4}$ emission from the ditch network has importance in the total emissions from peat extraction sites. However, the importance of ditches in the $\mathrm{CO}_{2}$ emissions is negligible (Sundh et al., 2000; Waddington and Day, 2007; Nykänen et al., 1996). The annual mean emissions from peat extraction sites shown in Fig. 1 do not include the emissions from ditches, since in most studies these emissions are not measured or calculated.

The wetlands constructed to purify runoff waters of peat extraction areas can also be sources of greenhouse gases ( $\mathrm{Li}-$ ikanen et al., 2006). The mean emission from these wetlands can change with time, associated with the development of vegetation. In the study by Liikanen et al. (2006), $\mathrm{CH}_{4}$ emissions increased from 140 to $400 \mathrm{mg} \mathrm{CH}_{4} \mathrm{~m}^{-2} \mathrm{~d}^{-1}$ and the ecosystem respiration increased from 7270 to $13600 \mathrm{mg} \mathrm{CO}_{2} \mathrm{~m}^{-2} \mathrm{~d}^{-1}$ from 5 to 15 years in operation, 
Table 3. Annual emissions of $\mathrm{CH}_{4}\left(\mathrm{~g} \mathrm{~m}^{-2} \mathrm{yr}^{-1}\right), \mathrm{N}_{2} \mathrm{O}\left(\mathrm{g} \mathrm{m}^{-2} \mathrm{yr}^{-1}\right)$ and net ecosystem $\mathrm{CO}_{2}$ exchange $\left(\mathrm{g} \mathrm{m}^{-2} \mathrm{yr}^{-1}, R=\mathrm{only} \mathrm{soil} \mathrm{res-}^{-1}\right.$ piration) from drained peatlands used for agriculture $(\mathrm{GR}=$ grass, $\mathrm{BR}=$ barley, $\mathrm{PO}=$ potato, $\mathrm{CA}=$ carrot, $\mathrm{AB}=$ abandoned with vegetation, $\mathrm{FA}=$ fallow without vegetation, $\mathrm{AF}=$ afforested with pine $-\mathrm{PI}-$ birch $-\mathrm{BI}-$ or alder $-\mathrm{AL})$, in the Nordic countries $(\mathrm{DK}=\mathrm{Denmark}$, $\mathrm{FI}=$ Finland, $\mathrm{IS}=\mathrm{Iceland}, \mathrm{NO}=$ Norway, $\mathrm{SE}=$ Sweden). A negative value indicates uptake, a positive value indicates emission. Methods are $\mathrm{CH}=$ chambers, $\mathrm{GC}=$ gas chromatograph, $\mathrm{IR}=$ infra-red analyzer and $\mathrm{EC}=$ eddy covariance method. If annual emission is estimated based on seasonal results the original measuring period (months from-to) is shown in column "Per." and the original emission value for that period in brackets.

\begin{tabular}{|c|c|c|c|c|c|c|c|c|c|c|}
\hline Site & Method & & Location & $\mathrm{C}: \mathrm{N}$ & $\mathrm{pH}$ & $\mathrm{CH}_{4}$ & $\mathrm{~N}_{2} \mathrm{O}$ & $\mathrm{CO}_{2}$ & Per. & Ref. \\
\hline GR & $\mathrm{CH}+\mathrm{GC}$ & FI & $62^{\circ} 40^{\prime} \mathrm{N}, 30^{\circ} 50^{\prime} \mathrm{E}$ & 19 & 5.3 & 0.13 & 1.3 & $2200^{R}$ & & $\mathrm{a}$ \\
\hline GR & $\mathrm{EC}$ & FI & $60^{\circ} 53^{\prime} \mathrm{N}, 23^{\circ} 30^{\prime} \mathrm{E}$ & 20 & 5.8 & ND & ND & 290 & & $\mathrm{~b}$ \\
\hline GR & $\mathrm{CH}+\mathrm{GC}$ & FI & $62^{\circ} 31^{\prime} \mathrm{N}, 29^{\circ} 23^{\prime} \mathrm{E}$ & 17 & 6.1 & -0.08 & 1.70 & ND & & $\mathrm{c}, \mathrm{d}$ \\
\hline GR & $\mathrm{CH}+\mathrm{GC}$ & FI & $62^{\circ} 46^{\prime} \mathrm{N}, 30^{\circ} 58^{\prime} \mathrm{E}$ & ND & 5.3 & ND & $1.74(1.35)$ & ND & $4-12$ & $\mathrm{e}$ \\
\hline GR & $\mathrm{CH}+\mathrm{IR}$ & FI & $62^{\circ} 31^{\prime} \mathrm{N}, 29^{\circ} 23^{\prime} \mathrm{E}$ & 17 & 6.1 & ND & ND & 2800 & & $\mathrm{f}$ \\
\hline GR & $\mathrm{CH}+\mathrm{GC}+\mathrm{IR}$ & FI & $65^{\circ} 55^{\prime} \mathrm{N}, 23^{\circ} 51^{\prime} \mathrm{E}$ & 33 & 4.4 & -0.10 & 0.4 & 1500 & & $\mathrm{~g}$ \\
\hline GR & $\mathrm{CH}+\mathrm{GC}$ & FI & $63^{\circ} 54^{\prime} \mathrm{N}, 23^{\circ} 56^{\prime} \mathrm{E}$ & 18 & 5.0 & -0.17 & 3.7 & ND & & $\mathrm{h}$ \\
\hline GR & $\mathrm{CH}+\mathrm{GC}$ & FI & $63^{\circ} 09^{\prime} \mathrm{N}, 27^{\circ} 20^{\prime} \mathrm{E}$ & 13 & 5.8 & -0.12 & 0.9 & ND & & $\mathrm{h}$ \\
\hline GR & $\mathrm{CH}+\mathrm{GC}$ & FI & $63^{\circ} 54^{\prime} \mathrm{N}, 23^{\circ} 56^{\prime} \mathrm{E}$ & 18 & 5.0 & 0.04 & 5.5 & $5780^{R}$ & & $\mathrm{i}$ \\
\hline GR & $\mathrm{CH}+\mathrm{GC}$ & FI & $60^{\circ} 49^{\prime} \mathrm{N}, 23^{\circ} 30^{\prime} \mathrm{E}$ & 21 & 5.8 & -0.03 & ND & ND & & $\mathrm{j}$ \\
\hline GR & $\mathrm{CH}+\mathrm{GC}$ & FI & $66^{\circ} 35^{\prime} \mathrm{N}, 26^{\circ} 01^{\prime} \mathrm{E}$ & 18 & 5.6 & 0.64 & ND & ND & & $\mathrm{j}$ \\
\hline GR & $\mathrm{CH}+\mathrm{GC}$ & FI & $60^{\circ} 49^{\prime} \mathrm{N}, 23^{\circ} 30^{\prime} \mathrm{E}$ & 21 & 5.8 & ND & 1.2 & ND & & $\mathrm{k}$ \\
\hline GR & $\mathrm{CH}+\mathrm{GC}$ & FI & $66^{\circ} 35^{\prime} \mathrm{N}, 26^{\circ} 01^{\prime} \mathrm{E}$ & 18 & 5.6 & ND & 0.63 & ND & & $\mathrm{k}$ \\
\hline GR & $\mathrm{CH}+\mathrm{GC}$ & $\mathrm{SE}$ & $58^{\circ} 20^{\prime} \mathrm{N}, 13^{\circ} 30^{\prime} \mathrm{E}$ & 10 & 7.4 & 0.12 & 0.20 & ND & & 1 \\
\hline GR & $\mathrm{CH}+\mathrm{GC}$ & $\mathrm{NO}$ & $67^{\circ} 17^{\prime} \mathrm{N}, 14^{\circ} 28^{\prime} \mathrm{E}$ & 17 & 5.2 & 1.6 & 0.69 & $4800^{R}$ & & $\mathrm{~m}$ \\
\hline GR & $\mathrm{CH}+\mathrm{GC}$ & NO & $67^{\circ} 17^{\prime} \mathrm{N}, 14^{\circ} 28^{\prime} \mathrm{E}$ & 17 & 5.2 & ND & ND & 2700 & & $\mathrm{n}$ \\
\hline GR & $\mathrm{CH}+\mathrm{GC}$ & $\mathrm{NO}$ & $67^{\circ} 17^{\prime} \mathrm{N}, 14^{\circ} 28^{\prime} \mathrm{E}$ & ND & 5.9 & 1.5 & 0.24 & ND & & $\mathrm{r}$ \\
\hline GR & $\mathrm{CH}+\mathrm{GC}$ & IS & $64^{\circ} 34^{\prime} \mathrm{N}, 21^{\circ} 46^{\prime} \mathrm{E}$ & 16 & 4.7 & ND & $0.05^{1}$ & ND & $5-8$ & o \\
\hline $\mathrm{PO}$ & $\mathrm{CH}+\mathrm{GC}$ & FI & $60^{\circ} 49^{\prime} \mathrm{N}, 23^{\circ} 30^{\prime} \mathrm{E}$ & 21 & 5.8 & ND & 1.57 & ND & & $\mathrm{k}$ \\
\hline BA & $\mathrm{EC}$ & FI & $60^{\circ} 53^{\prime} \mathrm{N}, 23^{\circ} 30^{\prime} \mathrm{E}$ & 20 & 5.8 & ND & ND & 771 & & $\mathrm{~b}$ \\
\hline BA & $\mathrm{CH}+\mathrm{GC}$ & FI & $62^{\circ} 31^{\prime} \mathrm{N}, 29^{\circ} 23^{\prime} \mathrm{E}$ & 17 & 6.1 & -0.24 & 1.3 & ND & & $\mathrm{c}, \mathrm{d}$ \\
\hline BA & $\mathrm{CH}+\mathrm{IR}$ & FI & $62^{\circ} 31^{\prime} \mathrm{N}, 29^{\circ} 23^{\prime} \mathrm{E}$ & 17 & 6.1 & ND & ND & 1500 & & $\mathrm{f}$ \\
\hline BA & $\mathrm{CH}+\mathrm{GC}+\mathrm{IR}$ & FI & $65^{\circ} 55^{\prime} \mathrm{N}, 23^{\circ} 51^{\prime} \mathrm{E}$ & 31 & 5.0 & -0.1 & 1.3 & 3000 & & $\mathrm{~g}$ \\
\hline BA & $\mathrm{CH}+\mathrm{GC}$ & FI & $60^{\circ} 49^{\prime} \mathrm{N}, 23^{\circ} 30^{\prime} \mathrm{E}$ & 21 & 5.8 & -0.03 & ND & ND & & $\mathrm{j}$ \\
\hline BA & $\mathrm{CH}+\mathrm{GC}$ & FI & $66^{\circ} 35^{\prime} \mathrm{N}, 26^{\circ} 01^{\prime} \mathrm{E}$ & 18 & 5.6 & 0.24 & ND & ND & & $\mathrm{j}$ \\
\hline $\mathrm{BA}$ & $\mathrm{CH}+\mathrm{GC}$ & FI & $60^{\circ} 49^{\prime} \mathrm{N}, 23^{\circ} 30^{\prime} \mathrm{E}$ & 21 & 5.8 & ND & 2.36 & ND & & $\mathrm{k}$ \\
\hline BA & $\mathrm{CH}+\mathrm{GC}$ & FI & $66^{\circ} 35^{\prime} \mathrm{N}, 26^{\circ} 01^{\prime} \mathrm{E}$ & 18 & 5.6 & ND & 2.04 & ND & & $\mathrm{k}$ \\
\hline BA & $\mathrm{CH}+\mathrm{GC}$ & $\mathrm{SE}$ & $58^{\circ} 20^{\prime} \mathrm{N}, 13^{\circ} 30^{\prime} \mathrm{E}$ & 10 & 7.2 & -0.01 & 1.51 & ND & & $\mathrm{p}$ \\
\hline $\mathrm{AB}^{3)}$ & $\mathrm{CH}+\mathrm{GC}$ & IS & $64^{\circ} 34^{\prime} \mathrm{N}, 21^{\circ} 46^{\prime} \mathrm{E}$ & 17 & 5.0 & ND & $0.07^{1}$ & ND & $5-8$ & o \\
\hline $\mathrm{AB}$ & $\mathrm{CH}+\mathrm{GC}$ & FI & $63^{\circ} 54^{\prime} \mathrm{N}, 23^{\circ} 56^{\prime} \mathrm{E}$ & 19 & 4.9 & 0.53 & 0.32 & 2980 & & $\mathrm{q}$ \\
\hline $\mathrm{AB}$ & $\mathrm{CH}+\mathrm{GC}$ & FI & $63^{\circ} 54^{\prime} \mathrm{N}, 23^{\circ} 56^{\prime} \mathrm{E}$ & 19 & 5.0 & -0.13 & 0.64 & 417 & & $\mathrm{q}$ \\
\hline $\mathrm{AB}$ & $\mathrm{CH}+\mathrm{GC}$ & FI & $63^{\circ} 54^{\prime} \mathrm{N}, 23^{\circ} 56^{\prime} \mathrm{E}$ & 18 & 5.9 & -0.06 & 0.48 & 287 & & $\mathrm{q}$ \\
\hline $\mathrm{AB}$ & $\mathrm{CH}+\mathrm{GC}$ & FI & $63^{\circ} 54^{\prime} \mathrm{N}, 23^{\circ} 56^{\prime} \mathrm{E}$ & 16 & 4.5 & -0.14 & 0.64 & 1870 & & $\mathrm{q}$ \\
\hline $\mathrm{AB}$ & $\mathrm{CH}+\mathrm{GC}$ & FI & $63^{\circ} 54^{\prime} \mathrm{N}, 23^{\circ} 56^{\prime} \mathrm{E}$ & 19 & 4.3 & -0.29 & 2.24 & 1060 & & $\mathrm{q}$ \\
\hline $\mathrm{AB}$ & $\mathrm{CH}+\mathrm{GC}$ & NO & $67^{\circ} 17^{\prime} \mathrm{N}, 14^{\circ} 28^{\prime} \mathrm{E}$ & ND & 5.2 & 0.04 & 0.99 & $4649^{R}$ & & $\mathrm{r}$ \\
\hline FA & $\mathrm{CH}+\mathrm{GC}$ & FI & $60^{\circ} 49^{\prime} \mathrm{N}, 23^{\circ} 30^{\prime} \mathrm{E}$ & 21 & 5.8 & ND & 0.69 & ND & & $\mathrm{k}$ \\
\hline FA & $\mathrm{CH}+\mathrm{GC}$ & FI & $66^{\circ} 35^{\prime} \mathrm{N}, 26^{\circ} 01^{\prime} \mathrm{E}$ & 18 & 5.6 & ND & 3.96 & ND & & $\mathrm{k}$ \\
\hline FA & $\mathrm{CH}+\mathrm{GC}$ & FI & $62^{\circ} 31^{\prime} \mathrm{N}, 29^{\circ} 23^{\prime} \mathrm{E}$ & 17 & 6.1 & -0.26 & 1.70 & 3360 & & $\mathrm{c}, \mathrm{d}$ \\
\hline FA & $\mathrm{CH}+\mathrm{GC}$ & FI & $65^{\circ} 55^{\prime} \mathrm{N}, 23^{\circ} 51^{\prime} \mathrm{E}$ & 31 & 5.0 & -0.04 & 3.70 & 2710 & & $\mathrm{~g}$ \\
\hline FA & $\mathrm{CH}+\mathrm{GC}$ & FI & $62^{\circ} 40^{\prime} \mathrm{N}, 30^{\circ} 50^{\prime} \mathrm{E}$ & 19 & 5.3 & -0.01 & 0.58 & 1450 & & $\mathrm{a}$ \\
\hline AF PI & $\mathrm{EC}$ & FI & $62^{\circ} 12^{\prime} \mathrm{N}, 22^{\circ} 42^{\prime} \mathrm{E}$ & ND & ND & ND & 0.94 & ND & & $\mathrm{s}$ \\
\hline AF BI & $\mathrm{CH}+\mathrm{GC}$ & $\mathrm{SE}$ & $58^{\circ} 20^{\prime} \mathrm{N}, 13^{\circ} 30^{\prime} \mathrm{E}$ & 13 & 3.0 & -0.8 & 3.05 & ND & & $\mathrm{t}$ \\
\hline AF PI & $\mathrm{EC}$ & FI & $62^{\circ} 10^{\prime} \mathrm{N}, 22^{\circ} 47^{\prime} \mathrm{E}$ & 22 & 4.8 & ND & ND & 50 & & $\mathrm{u}$ \\
\hline AF BI & $\mathrm{CH}+\mathrm{GC}$ & FI & $63^{\circ} 54^{\prime} \mathrm{N}, 23^{\circ} 56^{\prime} \mathrm{E}$ & 13 & 4.7 & $-0.15^{2}$ & 3.5 & ND & & $\mathrm{v}$ \\
\hline AF BI & $\mathrm{CH}+\mathrm{GC}$ & FI & $63^{\circ} 54^{\prime} \mathrm{N}, 23^{\circ} 56^{\prime} \mathrm{E}$ & 18 & 4.6 & $-0.15^{2}$ & 3.4 & ND & & $\mathrm{v}$ \\
\hline AF BI & $\mathrm{CH}+\mathrm{GC}$ & FI & $63^{\circ} 54^{\prime} \mathrm{N}, 23^{\circ} 56^{\prime} \mathrm{E}$ & 19 & 4.2 & $-0.15^{2}$ & 0.73 & ND & & $\mathrm{v}$ \\
\hline AF PI & $\mathrm{CH}+\mathrm{GC}$ & FI & $63^{\circ} 54^{\prime} \mathrm{N}, 23^{\circ} 56^{\prime} \mathrm{E}$ & 17 & 4.1 & $-0.15^{2}$ & 3.1 & ND & & $\mathrm{v}$ \\
\hline AF BI & $\mathrm{CH}+\mathrm{GC}$ & FI & $63^{\circ} 54^{\prime} \mathrm{N}, 23^{\circ} 56^{\prime} \mathrm{E}$ & 19 & 4.1 & $-0.15^{2}$ & 0.17 & ND & & $\mathrm{v}$ \\
\hline AF PI & $\mathrm{CH}+\mathrm{GC}$ & FI & $64^{\circ} 06^{\prime} \mathrm{N}, 24^{\circ} 21^{\prime} \mathrm{E}$ & 18 & 4.7 & $-0.15^{2}$ & 1.8 & ND & & $\mathrm{v}$ \\
\hline AF BI & $\mathrm{CH}+\mathrm{GC}$ & FI & $64^{\circ} 06^{\prime} \mathrm{N}, 24^{\circ} 21^{\prime} \mathrm{E}$ & 19 & 5.4 & $-0.15^{2}$ & 0.11 & ND & & $\mathrm{v}$ \\
\hline
\end{tabular}


Table 3. Continued.

\begin{tabular}{lllclllllll}
\hline Site & Method & & Location & $\mathrm{C}: \mathrm{N}$ & $\mathrm{pH}$ & $\mathrm{CH}_{4}$ & $\mathrm{~N}_{2} \mathrm{O}$ & $\mathrm{CO}_{2}$ & Per. & Ref. \\
\hline AF BI & $\mathrm{CH}+\mathrm{GC}$ & FI & $64^{\circ} 06^{\prime} \mathrm{N}, 24^{\circ} 21^{\prime} \mathrm{E}$ & 19 & 5.3 & $1.72(0.85)$ & $0.43(0.14)$ & $\left(2363^{R}\right)$ & $6-8$ & $\mathrm{w}$ \\
$\mathrm{AF} \mathrm{PI}$ & $\mathrm{CH}+\mathrm{GC}$ & $\mathrm{FI}$ & $64^{\circ} 06^{\prime} \mathrm{N}, 24^{\circ} 21^{\prime} \mathrm{E}$ & $\mathrm{ND}$ & 4.9 & $1.40(0.61)$ & $0.22(0.07)$ & $\left(1890^{R}\right)$ & $6-8$ & $\mathrm{w}$ \\
$\mathrm{AF} \mathrm{BI}$ & $\mathrm{CH}+\mathrm{GC}$ & $\mathrm{FI}$ & $64^{\circ} 06^{\prime} \mathrm{N}, 24^{\circ} 21^{\prime} \mathrm{E}$ & 19 & 4.7 & $-0.10(-0.05)$ & $0.97(0.32)$ & $\left(1098^{R}\right)$ & $6-8$ & $\mathrm{w}$ \\
$\mathrm{AF} \mathrm{AL}$ & $\mathrm{CH}+\mathrm{GC}$ & $\mathrm{SE}$ & $57^{\circ} 08^{\prime} \mathrm{N}, 14^{\circ} 45^{\prime} \mathrm{E}$ & 21 & 4.2 & 0.90 & 0.90 & $\mathrm{ND}$ & & $\mathrm{x}$
\end{tabular}

${ }^{1}$ average of preliminary results from three sites, drained but not ploughed sites, used for grazing occasionally; ${ }^{2}$ average of seven sites; ${ }^{3}$ drained but not used for croplands (a) Nykänen et al. (1995); (b) Lohila et al. (2004); (c) Maljanen et al. (2003a); (d) Maljanen et al. (2003b); (e) Regina et al. (1996); (f) Maljanen et al. (2001a); (g) Maljanen et al. (2004); (h) Maljanen et al. (2009); (i) Maljanen et al. (2010a); (j) Regina et al. (2007); (k) Regina et al. (2004); (1) Kasimir Klemedtsson et al. (2009); (m) Grønlund et al. (2006); (n) Grønlund et al. (2008); (o) J. Guðmundsson; AUI (unpubl.); (p) Kasimir Klemedtsson et al. (2009); (q) Maljanen et al. (2007a and unpublished data); (r) Kløve et al. (2010); (s) Pihlatie et al. (2004); (t) Weslien et al. (2009); (u) Lohila et al. (2007); (v) Mäkiranta et al. (2007); (w) Maljanen et al. (2001b); (x) Von Arnold et al. (2005c).

whereas $\mathrm{N}_{2} \mathrm{O}$ emissions remained similar, from 0.34 to $0.45 \mathrm{mg} \mathrm{N}_{2} \mathrm{O} \mathrm{m}^{-2} \mathrm{~d}^{-1}$.

However, there is still a lack of proper data on emissions associated with the various phases (e.g. drainage phase before harvesting) of peat utilization.

\section{Abandoned peat extraction sites}

Annually, about $20 \mathrm{~km}^{2}$ of extraction sites are abandoned both in Finland and Sweden. Therefore, the after use of peat extraction sites also has importance in the national GHG budgets. Some GHG measurements have been performed on abandoned peat extraction sites with no active after use (Tuittila et al., 2000, 2004; Tuittila and Komulainen, 1995; Nykänen et al., 1996). Abandoned sites emitted $0.26 \pm 0.03 \mathrm{~g} \mathrm{CH}_{4} \mathrm{~m}^{-2}(n=2), 0.08 \mathrm{~g} \mathrm{~N}_{2} \mathrm{O} \mathrm{m}^{-2}(n=1)$ and $231 \pm 423 \mathrm{~g} \mathrm{CO}_{2} \mathrm{~m}^{-2}(n=3)$ (Table 4$)$.

Afforestation and restoration are the most common afteruse options. Other options include e.g. energy crop cultivation. Results for the greenhouse gas balances of an abandoned peat extraction site growing perennial grass (reed canary grass) for energy are available in Finland (Table 4). In Finland, afforestation has been the most common after-use option for abandoned peat extraction sites. However, the GHG emission data from various after-use options is sparse. Methane and $\mathrm{N}_{2} \mathrm{O}$ results are reported for five afforested subsites from a former peat extraction area (Mäkiranta et al., 2007), but the data on the net $\mathrm{CO}_{2}$ exchange is lacking (Table 4).

\section{Cultivation of bioenergy crops on abandoned peat extraction sites}

GHG balances of a cut-away peatland used for cultivation of a bioenergy crop (reed canary grass, Phalaris arundinacea) have been studied in Finland over four years. In the cultivation of perennial reed canary grass soil is not ploughed after the first year since vegetation is established. During the rotation period of 10-15 years there is no ploughing but fertilizers are applied annually and sometimes lime. Therefore, there are fewer soil disturbances than in the production of annual crops, which could reduce the GHG emissions. The first results from Finland show uptake of $\mathrm{CO}_{2}$, the net annual $\mathrm{CO}_{2}$ exchange was $-365 \mathrm{~g} \mathrm{~m}^{-2}$, mean annual $\mathrm{CH}_{4}$ emission was $0.38 \mathrm{~g} \mathrm{~m}^{-2}$ and mean annual $\mathrm{N}_{2} \mathrm{O}$ emission was $0.09 \mathrm{~g} \mathrm{~m}^{-2}$ (Hyvönen et al., 2009; Shurpali et al., 2009). According to these results, the site has been a net sink for $\mathrm{C}$, and there is evidence that some carbon was allocated into the soil (Shurpali et al., 2010; C. Biasi, University of Eastern Finland, personal communication, 2010). The $\mathrm{N}_{2} \mathrm{O}$ emissions were much lower than those from croplands in general. However, it has to be pointed out that the data is available only for one site and the sites with variable peat characteristics have not been studied.

\section{Afforestation of peat extraction sites}

Annual $\mathrm{CH}_{4}$ and $\mathrm{N}_{2} \mathrm{O}$ balances have been studied for five sites within one peat extraction area in southern Finland (Mäkiranta et al., 2007), but there are no data on the net $\mathrm{CO}_{2}$ exchange from any site. As a result of low WT level, all sites were small sinks for $\mathrm{CH}_{4}$ and sources of $\mathrm{N}_{2} \mathrm{O}$. The mean annual $\mathrm{CH}_{4}$ flux rate was $-0.05 \pm 0.02 \mathrm{~g} \mathrm{~m}^{-2}$ and the mean annual $\mathrm{N}_{2} \mathrm{O}$ flux rate was $0.38 \pm 0.31 \mathrm{~g} \mathrm{~m}^{-2}$. Because there was no data on the net $\mathrm{CO}_{2}$ exchange, the GWP including all gases are not shown for afforested peat extraction sites in Fig. 1 .

\section{Restored drained petlands}

Interest in restoring formerly drained peatlands is increasing in the Nordic countries (e.g. UNFCCC, 2008; Petersen et al., 2009). In Denmark, for example, there are plans to restore nutrient rich fens drained for croplands. In Iceland, there are large areas of unproductive drained peatlands and the government has decided to include restoration of these wetlands as an action to decrease the national GHG emissions (Ministry for the Environment, 2007; Garðarsson et al., 2006). In Finland and Sweden, abandoned peat extraction areas could also be suitable for restoration (Vasander et al., 2003). At present, published data on the GHG emissions from restored peatlands in the Nordic countries are available 
Table 4. Annual balances of $\mathrm{CH}_{4}\left(\mathrm{~g} \mathrm{~m}^{-2} \mathrm{yr}^{-1}\right), \mathrm{N}_{2} \mathrm{O}\left(\mathrm{g} \mathrm{m}^{-2} \mathrm{yr}^{-1}\right)$ and net ecosystem $\mathrm{CO}_{2}$ exchange $\left(\mathrm{g} \mathrm{m}^{-2} \mathrm{yr}^{-1}\right)$ from peat extraction sites $(\mathrm{PE}=$ active site, $\mathrm{ABE}=$ abandoned, $\mathrm{AFE}=$ afforested with pine $-\mathrm{PI}-$ or birch $-\mathrm{BI}, \mathrm{REE}=$ restored, $\mathrm{RCG}=$ abandoned extraction site cultivated with reed canary grass) in Finland (FI) and Sweden (SE). Also, emissions from the ditches (DI) are shown. A negative value indicates uptake, a positive value indicates emission. Methods used for the measurements are $\mathrm{CH}+\mathrm{GC}=$ chamber method + analysis by gas chromatograph, $\mathrm{IF}+\mathrm{GC}=$ inverted funnel for gas collection from ditches, $\mathrm{CH}+\mathrm{IR}=$ chamber method + infra-red analyzer and $\mathrm{EC}=\mathrm{Eddy}$ covariance method. If annual emission is estimated based on seasonal results the original measuring period (months from-to) is shown in column "Per." and the original emission value for that period in brackets.

\begin{tabular}{|c|c|c|c|c|c|c|c|c|c|c|}
\hline Site & Method & & Location & $C: N$ & $\mathrm{pH}$ & $\mathrm{CH}_{4}$ & $\mathrm{~N}_{2} \mathrm{O}$ & $\mathrm{CO}_{2}$ & Per. & Ref. \\
\hline $\mathrm{PE}$ & $\mathrm{CH}+\mathrm{IR}$ & FI & $62^{\circ} 46^{\prime} \mathrm{N}, 30^{\circ} 58^{\prime} \mathrm{E}$ & ND & ND & ND & ND & 870 & & $\mathrm{a}$ \\
\hline $\mathrm{PE}$ & $\mathrm{CH}+\mathrm{GC}$ & FI & $62^{\circ} 30^{\prime} \mathrm{N}, 30^{\circ} 30^{\prime} \mathrm{E}$ & 42 & 4.3 & 0.99 & 0.004 & ND & & $\mathrm{b}$ \\
\hline $\mathrm{PE}$ & $\mathrm{CH}+\mathrm{IR}$ & FI & $62^{\circ} 30^{\prime} \mathrm{N}, 30^{\circ} 30^{\prime} \mathrm{E}$ & 42 & 4.3 & ND & ND & 381 & & $\mathrm{c}$ \\
\hline $\mathrm{PE}$ & $\mathrm{CH}+\mathrm{GC}$ & FI & $62^{\circ} 46^{\prime} \mathrm{N}, 30^{\circ} 58^{\prime} \mathrm{E}$ & ND & 4.6 & ND & $0.02(0.01)$ & ND & $5-12$ & $\mathrm{~d}$ \\
\hline $\mathrm{PE}$ & $\mathrm{CH}+\mathrm{GC}$ & FI & $62^{\circ} 47^{\prime} \mathrm{N}, 24^{\circ} 18^{\prime} \mathrm{E}$ & ND & ND & 0.32 & ND & 880 & & $\mathrm{e}$ \\
\hline PE, new & $\mathrm{CH}+\mathrm{GC}$ & FI & $62^{\circ} 40^{\prime} \mathrm{N}, 30^{\circ} 55^{\prime} \mathrm{E}$ & $\mathrm{ND}$ & $\mathrm{ND}$ & $0.24^{1}$ & $0.08^{1}$ & ND & & $\mathrm{e}$ \\
\hline $\mathrm{PE}$ & $\mathrm{CH}+\mathrm{GC}$ & FI & $62^{\circ} 40^{\prime} \mathrm{N}, 30^{\circ} 55^{\prime} \mathrm{E}$ & $\mathrm{ND}$ & $\mathrm{ND}$ & $0.24^{1}$ & $0.08^{1}$ & ND & & $\mathrm{e}$ \\
\hline PE & $\mathrm{CH}+\mathrm{GC}$ & $\mathrm{SE}$ & $64^{\circ} 05^{\prime} \mathrm{N}, 18^{\circ} 10^{\prime} \mathrm{E}$ & ND & ND & $4.97(2.88)$ & ND & $631(366)$ & $6-9$ & $\mathrm{f}$ \\
\hline $\mathrm{PE}$ & $\mathrm{CH}+\mathrm{GC}$ & SE & $64^{\circ} 55^{\prime} \mathrm{N}, 17^{\circ} 08^{\prime} \mathrm{E}$ & ND & ND & $4.97(2.88)$ & ND & $900(521)$ & $6-9$ & $\mathrm{f}$ \\
\hline $\mathrm{PE}$ & $\mathrm{CH}+\mathrm{GC}$ & $\mathrm{SE}$ & $64^{\circ} 05^{\prime} \mathrm{N}, 20^{\circ} 30^{\prime} \mathrm{E}$ & ND & ND & $0.11(0.04)$ & ND & $780(452)$ & $6-9$ & $\mathrm{f}$ \\
\hline $\mathrm{PE}$ & $\mathrm{CH}+\mathrm{GC}$ & $\mathrm{SE}$ & $64^{\circ} 05^{\prime} \mathrm{N}, 20^{\circ} 30^{\prime} \mathrm{E}$ & ND & ND & $0.11(0.04)$ & ND & $303(176)$ & $6-9$ & $\mathrm{f}$ \\
\hline $\mathrm{PE}$ & $\mathrm{CH}+\mathrm{GC}$ & $\mathrm{SE}$ & $60^{\circ} 20^{\prime} \mathrm{N}, 16^{\circ} 50^{\prime} \mathrm{E}$ & ND & ND & $0.05(0.03)$ & ND & $566(328)$ & $6-9$ & $\mathrm{f}$ \\
\hline $\mathrm{PE}$ & $\mathrm{CH}+\mathrm{GC}$ & $\mathrm{SE}$ & $60^{\circ} 03^{\prime} \mathrm{N}, 16^{\circ} 51^{\prime} \mathrm{E}$ & ND & ND & $1.14(0.67)$ & ND & 427 (248) & $6-9$ & $\mathrm{f}$ \\
\hline PE, new & $\mathrm{CH}+\mathrm{GC}$ & $\mathrm{SE}$ & $50^{\circ} 42^{\prime} \mathrm{N}, 16^{\circ} 17^{\prime} \mathrm{E}$ & ND & ND & $1.09(0.63)$ & ND & $1130(656)$ & $6-9$ & $\mathrm{f}$ \\
\hline PE, old & $\mathrm{CH}+\mathrm{GC}$ & SE & $50^{\circ} 42^{\prime} \mathrm{N}, 16^{\circ} 17^{\prime} \mathrm{E}$ & ND & ND & $-0.05(-0.03)$ & ND & $517(300)$ & $6-9$ & $\mathrm{f}$ \\
\hline $\mathrm{PE}$ & $\mathrm{CH}+\mathrm{IR}$ & FI & several sites & $\mathrm{ND}$ & ND & 7.23 & 0.31 & 980 & & $\mathrm{~g}$ \\
\hline $\mathrm{ABE}$ & $\mathrm{CH}+\mathrm{GC}$ & FI & $62^{\circ} 40^{\prime} \mathrm{N}, 30^{\circ} 55^{\prime} \mathrm{E}$ & ND & ND & $0.24^{1}$ & $0.08^{1}$ & ND & & $\mathrm{e}$ \\
\hline $\mathrm{ABE}$ & $\mathrm{CH}+\mathrm{GC}$ & FI & $62^{\circ} 12^{\prime} \mathrm{N}, 23^{\circ} 18^{\prime} \mathrm{E}$ & ND & ND & ND & ND & $661(333)$ & $6-9$ & $\mathrm{~h}$ \\
\hline $\mathrm{ABE}$ & $\mathrm{CH}+\mathrm{GC}$ & FI & $62^{\circ} 12^{\prime} \mathrm{N}, 23^{\circ} 18^{\prime} \mathrm{E}$ & ND & ND & $0.29(0.25)$ & ND & $\mathrm{ND}$ & $6-10$ & $\mathrm{i}$ \\
\hline $\mathrm{ABE}^{7}$ & $\mathrm{CH}+\mathrm{IR}$ & FI & $62^{\circ} 12^{\prime} \mathrm{N}, 23^{\circ} 18^{\prime} \mathrm{E}$ & ND & ND & ND & ND & $-185(-205)$ & $5-8$ & $\mathrm{j}$ \\
\hline $\mathrm{ABE}^{8}$ & $\mathrm{CH}+\mathrm{IR}$ & FI & $62^{\circ} 12^{\prime} \mathrm{N}, 23^{\circ} 18^{\prime} \mathrm{E}$ & ND & ND & ND & ND & $217(33)$ & $5-8$ & $\mathrm{j}$ \\
\hline REE $^{2)}$ & $\mathrm{CH}+\mathrm{IR}$ & FI & $62^{\circ} 12^{\prime} \mathrm{N}, 23^{\circ} 18^{\prime} \mathrm{E}$ & ND & ND & ND & ND & $-113(-275)$ & $5-9$ & $\mathrm{k}$ \\
\hline $\mathrm{REE}^{3}$ & $\mathrm{CH}+\mathrm{IR}$ & FI & $62^{\circ} 12^{\prime} \mathrm{N}, 23^{\circ} 18^{\prime} \mathrm{E}$ & ND & ND & ND & ND & $-95(-257)$ & $5-9$ & $\mathrm{k}$ \\
\hline $\mathrm{REE}^{4}$ & $\mathrm{CH}+\mathrm{IR}$ & FI & $62^{\circ} 12^{\prime} \mathrm{N}, 23^{\circ} 18^{\prime} \mathrm{E}$ & ND & ND & ND & ND & $-278(-440)$ & $5-9$ & $\mathrm{k}$ \\
\hline $\mathrm{REE}^{5}$ & $\mathrm{CH}+\mathrm{IR}$ & FI & $62^{\circ} 12^{\prime} \mathrm{N}, 23^{\circ} 18^{\prime} \mathrm{E}$ & ND & ND & ND & ND & $-159(-320)$ & $5-9$ & $\mathrm{k}$ \\
\hline $\mathrm{REE}^{6)}$ & $\mathrm{CH}+\mathrm{IR}$ & FI & $62^{\circ} 12^{\prime} \mathrm{N}, 23^{\circ} 18^{\prime} \mathrm{E}$ & ND & ND & 22.0 & ND & 34.8 & & $\mathrm{~m}$ \\
\hline $\mathrm{REE}^{6}$ & $\mathrm{CH}+\mathrm{IR}$ & FI & $62^{\circ} 12^{\prime} \mathrm{N}, 23^{\circ} 18^{\prime} \mathrm{E}$ & ND & ND & 36.7 & ND & 31.2 & & $\mathrm{~m}$ \\
\hline REE $^{6}$ & $\mathrm{CH}+\mathrm{IR}$ & FI & $62^{\circ} 12^{\prime} \mathrm{N}, 23^{\circ} 18^{\prime} \mathrm{E}$ & ND & ND & 48.0 & ND & 53.2 & & $\mathrm{~m}$ \\
\hline $\mathrm{REE}^{6}$ & $\mathrm{CH}+\mathrm{IR}$ & FI & $62^{\circ} 12^{\prime} \mathrm{N}, 23^{\circ} 18^{\prime} \mathrm{E}$ & ND & ND & 61.1 & ND & -143 & & $\mathrm{~m}$ \\
\hline REE & $\mathrm{CH}+\mathrm{IR}$ & FI & $62^{\circ} 12^{\prime} \mathrm{N}, 23^{\circ} 18^{\prime} \mathrm{E}$ & ND & ND & ND & ND & $-122(-237)$ & $5-9$ & $\mathrm{n}$ \\
\hline REE & $\mathrm{CH}+\mathrm{IR}$ & FI & $62^{\circ} 12^{\prime} \mathrm{N}, 23^{\circ} 18^{\prime} \mathrm{E}$ & ND & ND & ND & ND & $330(140)$ & $5-9$ & $\mathrm{n}$ \\
\hline $\mathrm{REE}^{7}$ & $\mathrm{CH}+\mathrm{IR}$ & FI & $62^{\circ} 12^{\prime} \mathrm{N}, 23^{\circ} 18^{\prime} \mathrm{E}$ & ND & ND & ND & ND & $-185(-205)$ & $5-8$ & $j$ \\
\hline $\mathrm{REE}^{8}$ & $\mathrm{CH}+\mathrm{IR}$ & FI & $62^{\circ} 12^{\prime} \mathrm{N}, 23^{\circ} 18^{\prime} \mathrm{E}$ & ND & ND & ND & ND & $217(33)$ & $5-8$ & $\mathrm{j}$ \\
\hline REE & $\mathrm{CH}+\mathrm{GC}$ & FI & $62^{\circ} 12^{\prime} \mathrm{N}, 23^{\circ} 18^{\prime} \mathrm{E}$ & ND & ND & $0.60(0.52)$ & ND & ND & $6-10$ & $\mathrm{i}$ \\
\hline REE & $\mathrm{CH}+\mathrm{GC}$ & FI & $62^{\circ} 12^{\prime} \mathrm{N}, 23^{\circ} 18^{\prime} \mathrm{E}$ & ND & ND & $1.50(0.99)$ & ND & ND & $6-10$ & $\mathrm{i}$ \\
\hline REE & $\mathrm{CH}+\mathrm{IR}$ & FI & $62^{\circ} 12^{\prime} \mathrm{N}, 23^{\circ} 18^{\prime} \mathrm{E}$ & ND & 4.1 & ND & ND & $-438(-500)$ & $(5-9)$ & o \\
\hline AFE, BI & $\mathrm{CH}+\mathrm{GC}$ & FI & $62^{\circ} 12^{\prime} \mathrm{N}, 23^{\circ} 18^{\prime} \mathrm{E}$ & 19 & 4.4 & $-0.05^{1}$ & 0.18 & ND & & $\mathrm{p}$ \\
\hline AFE, BI & $\mathrm{CH}+\mathrm{GC}$ & FI & $62^{\circ} 12^{\prime} \mathrm{N}, 23^{\circ} 18^{\prime} \mathrm{E}$ & 19 & 4.0 & $-0.05^{1}$ & 0.17 & ND & & $\mathrm{p}$ \\
\hline AFE, BI & $\mathrm{CH}+\mathrm{GC}$ & FI & $62^{\circ} 12^{\prime} \mathrm{N}, 23^{\circ} 18^{\prime} \mathrm{E}$ & 18 & 3.9 & $-0.05^{1}$ & 0.68 & ND & & $\mathrm{p}$ \\
\hline AFE, PI & $\mathrm{CH}+\mathrm{GC}$ & FI & $62^{\circ} 12^{\prime} \mathrm{N}, 23^{\circ} 18^{\prime} \mathrm{E}$ & 16 & 4.1 & $-0.05^{1}$ & 0.13 & ND & & $\mathrm{p}$ \\
\hline AFE, BI & $\mathrm{CH}+\mathrm{GC}$ & FI & $62^{\circ} 12^{\prime} \mathrm{N}, 23^{\circ} 18^{\prime} \mathrm{E}$ & 19 & 4.6 & $-0.05^{1}$ & 0.75 & ND & & $\mathrm{p}$ \\
\hline RCG & $\mathrm{EC}$ & FI & $62^{\circ} 30^{\prime} \mathrm{N}, 30^{\circ} 30^{\prime} \mathrm{E}$ & 42 & 5.3 & ND & ND & -365 & & $q$ \\
\hline RCG & $\mathrm{CH}+\mathrm{GC}$ & FI & $62^{\circ} 30^{\prime} \mathrm{N}, 30^{\circ} 30^{\prime} \mathrm{E}$ & 42 & 5.3 & 0.38 & 0.09 & ND & & $\mathrm{b}$ \\
\hline DI & $\mathrm{CH}+\mathrm{GC}$ & SE & $64^{\circ} 05^{\prime} \mathrm{N}, 18^{\circ} 10^{\prime} \mathrm{E}$ & ND & ND & $15.4(8.93)$ & ND & $547(317)$ & $6-9$ & $\mathrm{f}$ \\
\hline DI & $\mathrm{CH}+\mathrm{GC}$ & $\mathrm{SE}$ & $64^{\circ} 55^{\prime} \mathrm{N}, 17^{\circ} 08^{\prime} \mathrm{E}$ & ND & ND & $5.46(3.17)$ & ND & 209 (121) & $6-9$ & $\mathrm{f}$ \\
\hline DI & $\mathrm{CH}+\mathrm{GC}$ & $\mathrm{SE}$ & $64^{\circ} 05^{\prime} \mathrm{N}, 20^{\circ} 30^{\prime} \mathrm{E}$ & ND & ND & $6.01(0.12)$ & ND & $542(314)$ & $6-9$ & $\mathrm{f}$ \\
\hline DI & $\mathrm{CH}+\mathrm{GC}$ & SE & $64^{\circ} 05^{\prime} \mathrm{N}, 20^{\circ} 30^{\prime} \mathrm{E}$ & ND & ND & $11.4(0.23)$ & ND & $-408(-322)$ & $6-9$ & $\mathrm{f}$ \\
\hline DI & $\mathrm{CH}+\mathrm{GC}$ & $\mathrm{SE}$ & $60^{\circ} 20^{\prime} \mathrm{N}, 16^{\circ} 50^{\prime} \mathrm{E}$ & ND & ND & $15.9(9.22)$ & ND & $800(463)$ & $6-9$ & $\mathrm{f}$ \\
\hline DI & $\mathrm{CH}+\mathrm{GC}$ & SE & $60^{\circ} 03^{\prime} \mathrm{N}, 16^{\circ} 51^{\prime} \mathrm{E}$ & ND & ND & $79.5(46.1)$ & ND & $502(290)$ & $6-9$ & $\mathrm{f}$ \\
\hline
\end{tabular}


Table 4. Continued.

\begin{tabular}{lllclllllll}
\hline Site & Method & & Location & $C: N$ & $\mathrm{pH}$ & $\mathrm{CH}_{4}$ & $\mathrm{~N}_{2} \mathrm{O}$ & $\mathrm{CO}_{2}$ & Per. & Ref. \\
\hline DI, new & $\mathrm{CH}+\mathrm{GC}$ & $\mathrm{SE}$ & $50^{\circ} 42^{\prime} \mathrm{N}, 16^{\circ} 17^{\prime} \mathrm{E}$ & $\mathrm{ND}$ & $\mathrm{ND}$ & $124(72.0)$ & $\mathrm{ND}$ & $466(271)$ & $6-9$ & $\mathrm{f}$ \\
DI, old & $\mathrm{CH}+\mathrm{GC}$ & $\mathrm{SE}$ & $50^{\circ} 42^{\prime} \mathrm{N}, 16^{\circ} 17^{\prime} \mathrm{E}$ & $\mathrm{ND}$ & $\mathrm{ND}$ & $94.4(54.7)$ & $\mathrm{ND}$ & $-63(-92)$ & $6-9$ & $\mathrm{f}$ \\
DI, old & $\mathrm{IF}+\mathrm{GC}$ & FI & $62^{\circ} 47^{\prime} \mathrm{N}, 24^{\circ} 18^{\prime} \mathrm{E}$ & $\mathrm{ND}$ & $\mathrm{ND}$ & 0.23 & $\mathrm{ND}$ & 227 & $\mathrm{e}$ & $\mathrm{e}$ \\
DI, new & $\mathrm{IF}+\mathrm{GC}$ & FI & $62^{\circ} 47^{\prime} \mathrm{N}, 24^{\circ} 18^{\prime} \mathrm{E}$ & $\mathrm{ND}$ & $\mathrm{ND}$ & 137 & $\mathrm{ND}$ & 807 & & $\mathrm{e}$ \\
\hline
\end{tabular}

${ }^{1}$ mean values from three sites (e) or from five sites (p). ${ }^{2}$ Eriophorium; ${ }^{3}$ Carex; ${ }^{4}$ Eriophorium + Sphagnum; ${ }^{5}$ Carex + Sphagnum; ${ }^{6}$ Sphagnum; ${ }^{7}$ Sphagnum, dry; ${ }^{8}$ Sphagnum, wet;

(a) Ahlholm et al. (1990); (b) Hyvönen et al. (2009); (c) Shurpali et al. (2008); (d) Regina et al. (1996); (e) Nykänen et al. (1996); (f) Sundh et al. (2000); (g) Alm et al. (2007); (h) Tuittila et al. (1995); (i) Tuittila et al. (2000); (j) Tuittila et al. (2004); (k) Kivimäki et al. (2008); (m) Yli-Petäys et al. (2007); (n) Tuittila et al. (1999); (o) Soini et al. (2009); (p) Mäkiranta et al. (2007); (q) Shurpali et al. (2009)

only from Finland, where restoration of peatlands drained for forestry has been carried out in a small scale. Additionally, unpublished data exists from a case study in Iceland that compared GHG emissions from intact, drained and restored peatlands (H. Óskarsson, Agricultural university of Iceland, personal communication, 2009).

When peatlands are re-wetted, the WT level is elevated close to the soil surface in order to recreate a water logged situation, slow down the decomposition of OM and gain carbon to the system as peat. Increasing nutrient uptake by vegetation (e.g. Eriophorium vaginatum) also decreases $\mathrm{N}_{2} \mathrm{O}$ emissions (Silvan et al., 2005). A drawback, however, is the increase in $\mathrm{CH}_{4}$ emissions resulting from the anaerobic conditions in peat after elevation of the WT. Methane emissions have been reported from two restored originally forestry drained sites and from five peat extraction sites. $\mathrm{N}_{2} \mathrm{O}$ emissions have been reported from one restored forestry drained site and from two restored peat extraction sites. Net $\mathrm{CO}_{2}$ exchange is reported for two restored forest sites and five restored peat extraction sites (Tables 2 and 4).

The restored forest sites emitted methane with an average rate of $3.35 \pm 1.77 \mathrm{~g} \mathrm{CH}_{4} \mathrm{~m}^{-2} \mathrm{yr}^{-1}$ and methane emissions were highly dependent on the age of restoration (Waddington and Day, 2007; Höper et al., 2008). $\mathrm{N}_{2} \mathrm{O}$ emissions were only studied at one site. There, the annual $\mathrm{N}_{2} \mathrm{O}$ emission without fertilization was $0.55 \mathrm{~g} \mathrm{~N}_{2} \mathrm{O} \mathrm{m}^{-2}$ and $2.0 \mathrm{~g} \mathrm{~N}_{2} \mathrm{O} \mathrm{m}^{-2}$ with nitrate $\left(45 \mathrm{~kg} \mathrm{NO}_{3}^{-}-\mathrm{N} \mathrm{ha}^{-1} \mathrm{yr}^{-1}\right)$ fertilization (Silvan et al., 2002). These emissions were high compared to those from undrained peatlands having only minor $\mathrm{N}_{2} \mathrm{O}$ emissions (see Sect. 3.1). The net $\mathrm{CO}_{2}$ exchange during the growing season from the restored forestry drained ombrotrophic site was lower $\left(-275 \mathrm{~g} \mathrm{CO}_{2} \mathrm{~m}^{-2}\right)$ than that from the minerotrophic site $\left(-816 \mathrm{~g} \mathrm{CO}_{2} \mathrm{~m}^{-2}\right)$. The mean annual net $\mathrm{CO}_{2}$ exchange of a restored, originally forestry drained site including winter respiration (see Sect. 2.2) was $-440 \pm 377 \mathrm{~g} \mathrm{CO}_{2} \mathrm{~m}^{-2}$, indicating that these ecosystems act as carbon sinks after restoration.

The $\mathrm{CO}_{2}$ balance of restored peat extraction sites in Finland has been reported in five publications. Yli-Petäys et al. (2007) described annual emissions from an abandoned peat extraction site with natural develoment of peatland vegetation. The other studies have been carried out within the same restored site where re-vegetation was actively supported. However, in this case, measurements were only made during the growing season (Soini et al., 2009; Kivimäki et al., 2008; Tuittila et al., 1999, 2000, 2004) and winter emissions estimated by Yli-Petäys et al. (2007) were used to calculate the annual emissions (Table 4). The studied restored peat extraction sites have been sinks or sources for atmospheric $\mathrm{CO}_{2}$, depending on the time since restoration and vegetation cover. During the growing season there has been uptake of $\mathrm{CO}_{2}$, but in winter respiration $\mathrm{CO}_{2}$ loss has in some cases exceeded the uptake during summer. On average, there has been an annual uptake of $\mathrm{CO}_{2}, 67.0 \pm 202 \mathrm{~g} \mathrm{~m}^{-2}$, but there is a large variation among years (Table 4). Petrone et al. (2003) reported a net $\mathrm{CO}_{2}$ loss of about $1800 \mathrm{~g} \mathrm{~m}^{-2}$ from a vacuum harvested, restored peatland two years after restoration in Québeck, Canada. However, these results are not comparable with those from Finland, due to the different peat harvesting method (milling).

The restored ombrotrophic peat extraction sites studied in Finland did not emit any $\mathrm{N}_{2} \mathrm{O}$. The mean annual $\mathrm{CH}_{4}$ emission from two restored ombrotrophic sites three years after rewetting was from 0.62 to $1.46 \mathrm{~g} \mathrm{~m}^{-2}$ (Tuittila et al., 2000). However, in four subsites in another study area about 50 years after extraction and with natural development of vegetation, emissions were higher, ranging from 18.7 from $45.2 \mathrm{~g} \mathrm{~m}^{-2}$ (Yli-Petäys et al., 2007). This range is much higher than the average $\mathrm{CH}_{4}$ emission from unmanaged ombrotrophic peatlands (see above). The average annual $\mathrm{CH}_{4}$ emission of restored peat extraction sites was thus $21.8 \pm 18.4 \mathrm{~g} \mathrm{~m}^{-2}$. Waddington and Day (2007) reported seasonal (May-October) methane emissions of $4.2 \mathrm{~g} \mathrm{~m}^{-2}$ for a restored peat extraction site in Canada (Québec) three years after restoration, which is close to the results by Tuittila et al. (1999). The site in Canada did not emit $\mathrm{CH}_{4}$ prior to restoration. Similar to the peat extraction sites, ditches and ponds can act as hot spots for $\mathrm{CH}_{4}$ emissions in restored sites (Waddington and Day, 2007), but this data is not available for the peatlands in the Nordic countries. 
Some unpublished data exist for a case study in western Iceland comparing the GHG balance of an intact, restored and drained minerotrophic peatland sites (H. Óskarsson, Agricultural university of Iceland). Chamber measurements were done year round from unmanaged, drained but not cultivated and restored sites. The estimated annual net $\mathrm{CO}_{2}$ exchange of the unmanaged and restored sites indicates that they are sinks for atmospheric $\mathrm{CO}_{2}$ with an annual uptake of $-530 \mathrm{~g} \mathrm{~m}^{-2}$ for the unmanaged site and $-330 \mathrm{~g} \mathrm{~m}^{-2}$ for the restored site, whereas the drained site was a net source of $\mathrm{CO}_{2}$ with an annual value of $910 \mathrm{~g} \mathrm{~m}^{-2}$. Estimated annual emission $\mathrm{N}_{2} \mathrm{O}$ rates for the drained, unmanaged and restored sites were low; $0.11,0.005$, and $0.014 \mathrm{~g} \mathrm{~m}^{-2}$, and their annual $\mathrm{CH}_{4}$ emissions were estimated to be $0.8,18$ and $17 \mathrm{~g} \mathrm{~m}^{-2}$, respectively. In this case the rewetting of noncultivated drained peatlands did restore the net GHG fluxes to pre-drainage levels.

\subsection{Relations between soil characteristics and $\mathrm{CH}_{4}$ and $\mathrm{N}_{2} \mathrm{O}$ fluxes on drained peat soils}

The data in Fig. 2 includes all annual emissions from peat soils drained for forestry, agricultural soils, afforested agricultural soils and peat extraction sites where information about soil $\mathrm{pH}$ and $C / N$ ratios was available and excludes the data for rewetted sites. The $C / N$ ratio in most sites with high $\mathrm{N}_{2} \mathrm{O}$ emissions was between 15 and 22, in accordance with the results presented by Klemedtsson et al. (2005). However, there was a high variation in annual flux rates within this $C / N$ range. In general, soils with a $C / N$ ratio lower than 15 or higher than 22 had low $\mathrm{N}_{2} \mathrm{O}$ emissions. The two exceptions with high $C / N$ ratio and high $\mathrm{N}_{2} \mathrm{O}$ emission were agricultural soils where e.g. N-fertilization and ploughing may have overridden the $C / N$ dependence, thus indicating that the availability of mineral nitrogen for microbial processes (nitrification, denitrification) is important for $\mathrm{N}_{2} \mathrm{O}$ production.

Methane emissions seemed to have an increasing trend with increasing $C / N$ ratio, however the regression was not significant. Most of the sites having a $C / N$ ratio in the range from 15 to 22 had close to zero $\mathrm{CH}_{4}$ fluxes.

Most of the studied drained soils had their $\mathrm{pH}$ in the 3 to 6 range (Tables 2-4). $\mathrm{N}_{2} \mathrm{O}$ emissions were highly variable within this range. The sites with a pH less than 4 or over 6 seemed to have low $\mathrm{N}_{2} \mathrm{O}$ emissions. However, there was no significant correlation between soil $\mathrm{pH}$ and $\mathrm{N}_{2} \mathrm{O}$ emission in the present study. This finding was in contrast to Weslien et al. (2009), who found a relationship between $\mathrm{pH}$ and $\mathrm{N}_{2} \mathrm{O}$ emission in afforested agricultural soil. In managed peat soils, fertilization and liming may alter the soil $\mathrm{pH}$ as can been seen in Fig. 2, where the mean $\mathrm{pH}$ was higher in agricultural soils (5.5) than in peat soils drained for forestry (3.8). The highest $\mathrm{CH}_{4}$ emissions occurred from soils with a low $\mathrm{pH}$, which is in agreement with the findings by Weslien et al. (2009). The sites with a low $\mathrm{pH}$ were forestry drained

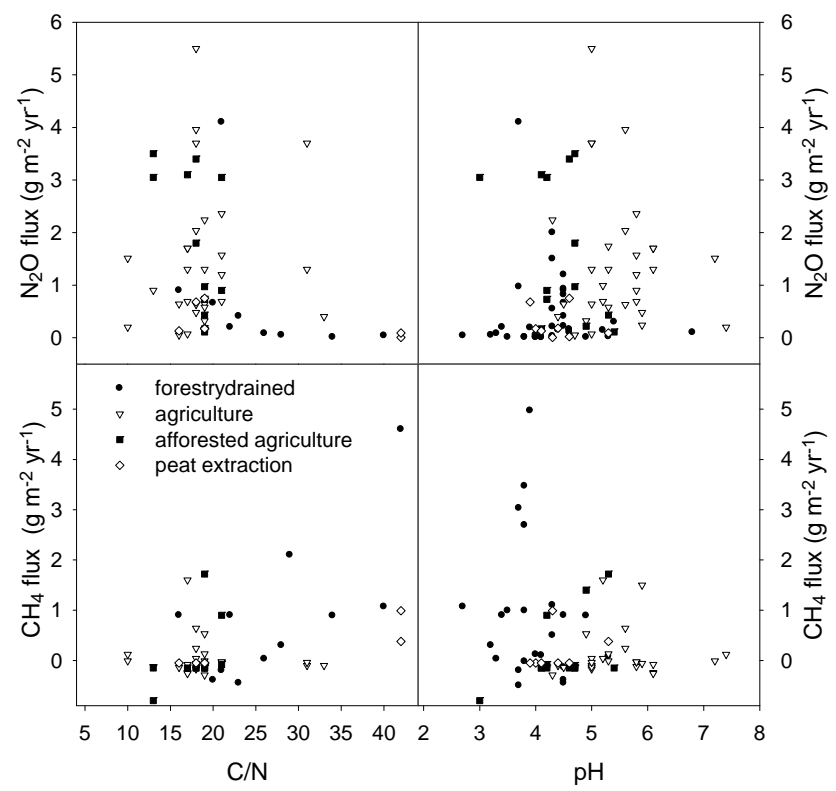

Fig. 2. Relationships between annual fluxes of $\mathrm{N}_{2} \mathrm{O}$ and $\mathrm{CH}_{4}$ and soil $\mathrm{C} / \mathrm{N}$ ratio and soil $\mathrm{pH}$ on drained peat soils (black circle $=$ forestry drained, open triangle $=$ agriculture, black square $=$ afforested agricultural soils, open diamond $=$ peat extraction sites).

sites, where a higher WT level in old drainage systems could explain the higher $\mathrm{CH}_{4}$ emission.

Soil $\mathrm{CH}_{4}$ and $\mathrm{N}_{2} \mathrm{O}$ fluxes had a nonlinear relationship (Fig. 3). $\mathrm{CH}_{4}$ emissions occurred only when $\mathrm{N}_{2} \mathrm{O}$ emissions were low. Weslien et al. (2009) found a similar relationship, increasing $\mathrm{N}_{2} \mathrm{O}$ emissions with increasing $\mathrm{CH}_{4}$ emissions. When several different sites are compared, WT depth or soil moisture may be the key factor for controlling GHG emissions. However, soil WT data were available only from few sites and this comparison was therefore not possible.

\subsection{Water reservoirs and artificial lakes}

One of the land use options affecting the GHG balance of peatland is flooding of the soil, as when water reservoirs are established. The land impounded is in most cases a mixture of both mineral and organic soils. Measurements on the GHG fluxes are accordingly indirect in so far as the peatland is concerned, as gases are dissolved in the flood water before being emitted.

\subsubsection{GHG emissions from water reservoirs}

The data published to date from the Nordic reservoirs are summarized in Table 5. In Finland, the fluxes of all three GHGs have been measured in two large hydroelectric reservoirs (Lokka and Porttipahta) in northern Finland (Huttunen et al., 2002b). These reservoirs flooded large areas of unmanaged peatland within the river Kemijoki watercourse, $76 \%$ 


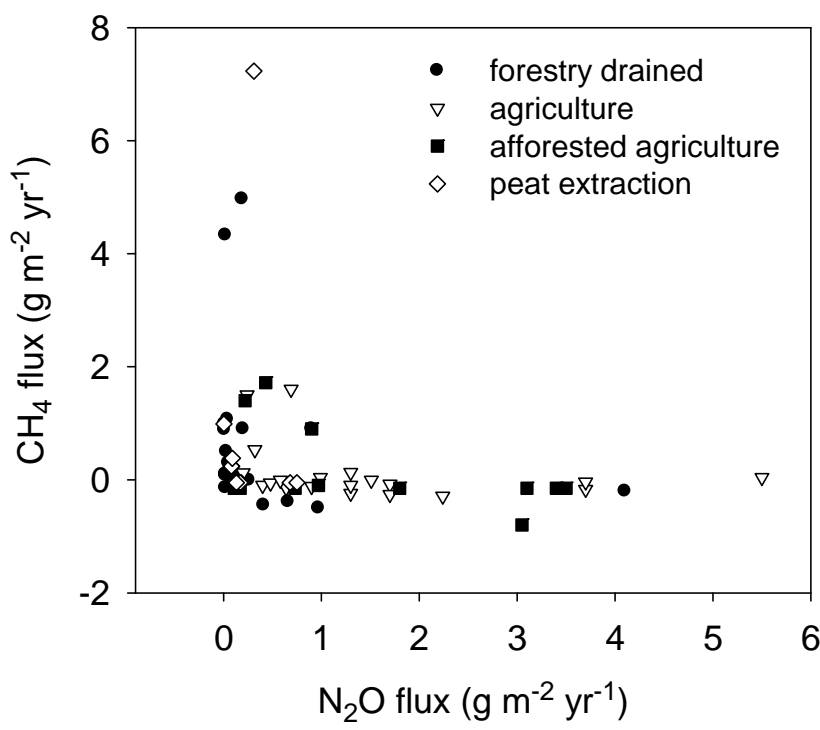

Fig. 3. Relationships between annual fluxes of $\mathrm{N}_{2} \mathrm{O}$ and $\mathrm{CH}_{4}$ on drained peat soils (black circle $=$ forestry drained, open triangle $=$ agriculture, black square $=$ afforested agricultural soils, open diamond $=$ peat extraction sites).

and $45 \%$ of their maximum area is on natural peatlands, respectively. Measurements included flux determinations with floating chambers, while $\mathrm{CH}_{4}$ ebullition was measured continuously using bubble traps (Table 5). Because the chambers sometimes recorded higher or similar $\mathrm{CH}_{4}$ emissions as the bubble traps, even chamber results were considered to represent "total $\mathrm{CH}_{4}$ emissions" including the possible contribution of small bubbles in the $\mathrm{CH}_{4}$ flux to the chambers (Huttunen et al., 2002b).

Emissions of $\mathrm{CO}_{2}$ were calculated with the thin boundary layer (TBL) approach from one reservoir flooding an area of $20 \mathrm{~km}^{2}$ in northern Sweden, of which $30 \%$ was previously peatland, mesotrophic Skinnmuddselet within the River Gideälven (Åberg et al., 2004; Table 5). The partial pressure of $\mathrm{CO}_{2}$ in water $\left(p \mathrm{CO}_{2}\right)$ was measured in a subset of hydropower reservoirs with $49-354 \mathrm{~km}^{2}$ flooded area along seven regulated rivers in northern Sweden and then modeled for the total flooded area based on the relationship between DOC and dissolved $\mathrm{CO}_{2}$ in lake and reservoir. The $\mathrm{CO}_{2}$ exchange at the water-air interface was then calculated using the TBL method (Bergström et al., 2004). These reservoirs were oligotrophic and flooded mostly mineral soils and previous water bodies in alpine forest areas.

Fluxes of $\mathrm{CH}_{4}, \mathrm{CO}_{2}$ and $\mathrm{N}_{2} \mathrm{O}$ were measured on the Gilsárlón hydropower reservoir in northern Iceland (area $4.3 \mathrm{~km}^{2}$, average depth $9 \mathrm{~m}$, constructed in 1990; Óskarsson and Guðmundsson, 2008a,b). Of the area impounded, 67\% was peatland. The $\mathrm{CH}_{4}$ and $\mathrm{N}_{2} \mathrm{O}$ diffusive fluxes were measured with floating chambers and $\mathrm{CH}_{4}$ ebullition with bubble traps. The $\mathrm{CO}_{2}$ emission was measured with $\mathrm{EC}$ and floating chambers.
There are also preliminary data on the $\mathrm{CH}_{4}$ and $\mathrm{CO}_{2}$ emissions from one reservoir in the Follsjø area in mid-Norway $6.5 \mathrm{~km}^{2}$, constructed in 1968 , with $8.6 \%$ of the impounded area as peat.

Degassing emissions at the spring ice melt or those from the outflowing waters downstream of the dam are not included in the data. The $\mathrm{CH}_{4}$ release greatly differed between the two reservoirs studied in Finland, both of them flooding extensive areas of former peatlands. The chamber measurements indicated up to ten times higher $\mathrm{CH}_{4}$ release from Lokka compared with Porttipahta, In Lokka, the ebullitive fluxes had a seasonal mean value of $26 \mathrm{~g} \mathrm{CH}_{4} \mathrm{~m}^{-2} \mathrm{yr}^{-1}$ and in Porttipahta, $\mathrm{CH}_{4}$ ebullition was almost negligible. The high $\mathrm{CH}_{4}$ emissions from Lokka have been attributed to its relatively high trophic state and anoxic conditions in the sediment, although the water column was effectively mixed and aerated by wind during the open water season (Huttunen et al., 2002b). Moreover, the persistence of the high $\mathrm{CH}_{4}$ release in this 27 year old reservoir was suggested to be mainly fuelled by relatively fresh organic carbon, based on the relatively high modern carbon content of $\mathrm{CH}_{4}$ in the bubbles released from its sediment (Huttunen et al., 2002b). The erosion caused by wind and wave action has been identified as an important source of internal nutrient loading in this shallow eutrophic reservoir (Hellsten et al., 1993), which was further reflected in its relatively high autochthonous primary production (Huttunen et al., 2002b). The data from the Icelandic site shows similarly high $\mathrm{CH}_{4}$ release from the younger Gilsárlón reservoir, also constructed mainly on previous peatland, releasing annually about $9-11 \mathrm{~g} \mathrm{CH}_{4} \mathrm{~m}^{-2}$, of which most was due to $\mathrm{CH}_{4}$ ebullition (Óskarsson and Guðmundsson, 2008b). In Follsjø reservoir in Norway, where peatland contributed less than $10 \%$ to the flooded area, $\mathrm{CH}_{4}$ release was observed during the spring in association with a major water level drawdown of $>25 \mathrm{~m}$, but during the openwater season with higher water levels, emissions were at the detection limit (Harby et al., 2006).

The $\mathrm{CH}_{4}$ emissions from the Nordic sites presented above correspond to the emissions reported from 34 reservoirs during open water conditions in British Columbia, Manitoba/Ontario and Quebec, Canada (Tremblay et al., 2005). These emissions were from close to zero to $17 \mathrm{~g} \mathrm{CH}_{4} \mathrm{~m}^{-2} \mathrm{yr}^{-1}$, calculated from daily emissions (assuming an active period of 150 days; Tremblay et al., 2005). The Nordic data suggests that age does not have a major role in explaining the long-term emission rates among the reservoirs, although $\mathrm{CH}_{4}$ emissions are known to decrease within some year after a phase of rapid decomposition of flooded fresh organic matter following flooding (e.g. Bodaly et al., 2004). The shallow water column in Lokka (mean depth 2.3-5.0 m) and Gilsárlón (mean depth $9 \mathrm{~m}$ ) would have favoured the release of $\mathrm{CH}_{4}$, since ebullition is likely to occur at shallow water depths, from one to $10 \mathrm{~m}$ (Keller and Stallard, 1994). This $\mathrm{CH}_{4}$ escaping from the sediments via bubbles also bypasses possible $\mathrm{CH}_{4}$ oxidation in the water 
Table 5. Gross GHG emissions $\left(\mathrm{g} \mathrm{m}^{-2} \mathrm{yr}^{-1}\right)$ from hydroelectric reservoirs in the Nordic countries $(\mathrm{FI}=\mathrm{Finland}, \mathrm{SE}=\mathrm{Sweden}, \mathrm{IC}=\mathrm{Iceland})$. Methods are $\mathrm{FC}=$ gas sampling of floating chamber $+\mathrm{GC}$ analyses; $\mathrm{EB}=$ recording of ebullition by bubble traps $+\mathrm{GC}$ analyses $(\mathrm{EBf}=\mathrm{ice}$ free, $\mathrm{EBi}=\mathrm{ice}$ ); $\mathrm{TBL}=$ water sampling for $p \mathrm{CO}_{2}$ and the flux calculation by the TBL method. Only the GHG fluxes during open-water season are presented here.

\begin{tabular}{|c|c|c|c|c|c|c|}
\hline Site & Meth. & Location & Flooded land & $\mathrm{CH}_{4}$ & $\mathrm{~N}_{2} \mathrm{O}$ & $\mathrm{CO}_{2}$ \\
\hline \multirow[t]{2}{*}{ Lokka } & $\mathrm{FC}$ & FI $67^{\circ} 48^{\prime} \mathrm{N}, 27^{\circ} 01^{\prime} \mathrm{E}$ & $\begin{array}{l}\text { forest } 21 \% \\
\text { mire } 75.7 \% \\
\text { water } 3.3 \%\end{array}$ & $1.8-4.7$ & $0.002-0.01$ & $152-280^{1}$ \\
\hline & EB & FI $67^{\circ} 48^{\prime} \mathrm{N}, 27^{\circ} 01^{\prime} \mathrm{E}$ & & $6.6-26$ & & \\
\hline Porttipahta & $\mathrm{FC}$ & FI $68^{\circ} 02^{\prime} \mathrm{N}, 26^{\circ} 46^{\prime} \mathrm{E}$ & $\begin{array}{l}\text { forest } 44.7 \% \\
\text { mire } 54.6 \% \\
\text { water } 0.4 \%\end{array}$ & 0.53 & 0.02 & $232^{1}$ \\
\hline Skinnmuddselet & $\begin{array}{l}\mathrm{EB} \\
\mathrm{TBL}\end{array}$ & $\mathrm{SE} 63^{\circ} 59^{\prime} \mathrm{N}, 18^{\circ} 26^{\prime} \mathrm{E}$ & $\begin{array}{l}\text { forest } 55 \% \\
\text { mire } 33 \% \\
\text { water } 15 \%\end{array}$ & $\begin{array}{l}0.11 \\
\mathrm{ND}\end{array}$ & ND & $87.6^{2}$ \\
\hline R. Ljusnan/Voxnan ${ }^{\mathrm{a}}$ & TBL & SE $63-67^{\circ} \mathrm{N}, 13-19^{\circ} \mathrm{E}$ & $\mathrm{b}$ & ND & ND & $101^{3}$ \\
\hline R. Ljungan ${ }^{\mathrm{a}}$ & TBL & SE $63-67^{\circ} \mathrm{N}, 13-19^{\circ} \mathrm{E}$ & $\mathrm{b}$ & ND & ND & $59.7^{3}$ \\
\hline R. Indal ${ }^{\mathrm{a}}$ & TBL & SE $63-67^{\circ} \mathrm{N}, 13-19^{\circ} \mathrm{E}$ & $\mathrm{b}$ & ND & ND & $61.6^{3}$ \\
\hline R. Ångerman ${ }^{\mathrm{a}}$ & TBL & SE $63-67^{\circ} \mathrm{N}, 13-19^{\circ} \mathrm{E}$ & $\mathrm{b}$ & ND & ND & $41.1^{3}$ \\
\hline R. Ume $\mathrm{e}^{\mathrm{a}}$ & TBL & SE $63-67^{\circ} \mathrm{N}, 13-19^{\circ} \mathrm{E}$ & $\mathrm{b}$ & ND & ND & $21.2^{3}$ \\
\hline R. Skellefte ${ }^{a}$ & TBL & SE $63-67^{\circ} \mathrm{N}, 13-19^{\circ} \mathrm{E}$ & $\mathrm{b}$ & ND & ND & $12.6^{3}$ \\
\hline R. Lule ${ }^{\mathrm{a}}$ & TBL & SE $63-67^{\circ} \mathrm{N}, 13-19^{\circ} \mathrm{E}$ & $\mathrm{b}$ & ND & ND & $8.0^{3}$ \\
\hline \multirow[t]{4}{*}{ Gilsárlón } & $\mathrm{FC}$ & IC $62^{\circ} 57^{\prime} \mathrm{N}, 09^{\circ} 07^{\prime} \mathrm{E}$ & $\begin{array}{l}\text { heath }+ \text { dwarf shrubs } 33 \% \\
\text { Peatland } 67 \%\end{array}$ & $0.41-0.57$ & 0.0 & $\mathrm{ND}^{4)}$ \\
\hline & $\mathrm{EBf}$ & IC $62^{\circ} 57^{\prime} \mathrm{N}, 09^{\circ} 07^{\prime} \mathrm{E}$ & & $8.6-10.2$ & ND & $\mathrm{ND}^{4}$ \\
\hline & EB i & $\mathrm{IC} 62^{\circ} 57^{\prime} \mathrm{N}, 09^{\circ} 07^{\prime} \mathrm{E}$ & & 0.4 & ND & $\mathrm{ND}^{4}$ \\
\hline & $\mathrm{EC}$ & IC $62^{\circ} 57^{\prime} \mathrm{N}, 09^{\circ} 07^{\prime} \mathrm{E}$ & & ND & ND & $180^{5}$ \\
\hline
\end{tabular}

${ }^{1}$ Huttunen et al. (2002b); ${ }^{2}$ Åberg et al. (2004); ${ }^{3}$ Bergström et al. (2004); ${ }^{4}$ Óskarsson and Guðmundsson (2008b); ${ }^{5}$ Óskarsson and Guðmundsson (2008a)

a Data from several reservoirs within each dammed river.

$\mathrm{b}$ The sites represent dammed regulated rivers located on alpine forest areas, the preflood water surface areas accounted for $57-92 \%$ of the postflood surface area in the different rivers.

column. Duchemin et al. (1995) also reported higher $\mathrm{CH}_{4}$ emissions from shallower $(<3 \mathrm{~m})$ than deeper $(>7 \mathrm{~m})$ stations in LaGrande-2 and Laforge-1 reservoirs in Quebec, and suggested that $\mathrm{CH}_{4}$ oxidation was important in controlling the $\mathrm{CH}_{4}$ fluxes from sediments to the atmosphere.

The two Finnish lowland reservoirs and the Icelandic reservoir also showed higher $\mathrm{CO}_{2}$ release during the open water season than the oligotrophic Swedish sites (Table 5) and Follsjø in Norway (estimated annual emission $139 \mathrm{~g} \mathrm{~m}^{-2} \mathrm{yr}^{-1}$; Harby et al., 2006). However, all these emissions ranged from 8 to $280 \mathrm{~g} \mathrm{~m}^{-2} \mathrm{yr}^{-1}$ and were within the range of -155 to $860 \mathrm{~g} \mathrm{CO}_{2} \mathrm{~m}^{-2} \mathrm{yr}^{-1}$ (150 days active period assumed) measured for the $\mathrm{CO}_{2}$ fluxes from 55 reservoir sites in British Columbia, Manitoba/Ontario, Quebec and New Foundland, Canada, in campaigns during the openwater season (Tremblay et al., 2005). Due to a high range of $\mathrm{CO}_{2}$ emissions from various boreal reservoirs, the sources of $\mathrm{CO}_{2}$, whether being within a reservoir or catchment area, need to be identified to allow estimation of potential $\mathrm{CO}_{2}$ emissions from any planned reservoir in the boreal region.

\subsubsection{Emissions at spring ice melt}

The springtime mixing of the water-column can make an important contribution to annual GHG emissions from northern reservoirs. At the deepest site in Porttipahta, Finland, GHG emissions were measured during the mixing period after the ice melt with floating chambers and the changes in the GHG profiles in the water were simultaneously determined (Huttunen et al. 2002b). The springtime emissions accounted for most of the annual $\mathrm{CH}_{4}$ release at that site, while the $\mathrm{CO}_{2}$ and $\mathrm{N}_{2} \mathrm{O}$ emissions during the overturn corresponded to the $\mathrm{CO}_{2}$ and $\mathrm{N}_{2} \mathrm{O}$ emissions during the rest of the season. In Follsjø in Norway, the annual $\mathrm{CH}_{4}$ release, resulting only from the springtime degassing emission, was estimated at $7.7 \mathrm{~g} \mathrm{CH}_{4} \mathrm{~m}^{-2} \mathrm{yr}^{-1}$ (Harby et al., 2006). At the Swedish sites studied by Bergström et al. (2004), emptying of the reservoirs in January-May was estimated to result in $\mathrm{CO}_{2}$ emissions which were $2.6-7.4 \%$ of the values presented for the open water season (Table 5). The emptying of the reservoir Skinnmuddsselet in Sweden was estimated to result 
Talbe 6. Annual GHG emissions from peatland ecosystems vs. mineral soils used for forestry or agriculture based on studies in the Nordic countries. Negative values indicate net uptake and positive values net emission from the ecosystem (Mean $=$ average of all studies, Min = lowest value, Max $=$ highest value, $n=$ number of studies).

\begin{tabular}{|c|c|c|c|c|c|c|c|c|}
\hline \multirow[t]{2}{*}{$\operatorname{Gas}\left(\mathrm{g} \mathrm{m}^{-2} \mathrm{yr}^{-1}\right)$} & \multicolumn{4}{|c|}{ Agriculture, peat soil ${ }^{\mathrm{a}}$} & \multicolumn{4}{|c|}{ Agriculture, mineral soil ${ }^{\mathrm{c}}$} \\
\hline & Mean & Min & $\operatorname{Max}$ & $n$ & Mean & Min & Max & $n$ \\
\hline Net $\mathrm{CO}_{2}$ exchange & 1790 & 290 & 3040 & 7 & -741 & - & - & 1 \\
\hline $\mathrm{CH}_{4}$ flux & 0.21 & -0.24 & 1.56 & 16 & -0.05 & -0.26 & 0.03 & 16 \\
\hline $\mathrm{N}_{2} \mathrm{O}$ flux & 1.56 & 0.20 & 5.50 & 17 & 0.34 & 0.05 & 0.64 & 26 \\
\hline \multirow[t]{3}{*}{ Total GWP as $\mathrm{CO}_{2}$ eq. } & 2260 & & & & -640 & & & \\
\hline & \multicolumn{4}{|c|}{ Forest, peat soil ${ }^{b}$} & \multicolumn{4}{|c|}{ Forest, mineral soil ${ }^{\mathrm{d}}$} \\
\hline & Mean & Min & $\operatorname{Max}$ & $n$ & Mean & Min & $\operatorname{Max}$ & $n$ \\
\hline Net $\mathrm{CO}_{2}$ exchange & -900 & - & - & 1 & -480 & -1100 & 760 & 16 \\
\hline $\mathrm{CH}_{4}$ flux & 0.65 & -0.87 & 4.76 & 40 & -0.26 & -0.76 & -0.03 & 11 \\
\hline $\mathrm{N}_{2} \mathrm{O}$ flux & 0.32 & $>0.001$ & 4.10 & 44 & 0.04 & -0.01 & 0.11 & 16 \\
\hline Total GWP as $\mathrm{CO}_{2}$ eq. & -790 & & & & -480 & & & \\
\hline
\end{tabular}

\footnotetext{
${ }^{a}$ Data from Table 3. excluding fallow and abandoned soils. ${ }^{b}$ Data from Table 2. excluding clear cut and restored sites. ${ }^{\mathrm{c}}$ Data from Ambus (1998); Ambus et al. ( 2001); Chatskikh and Olesen, (2007); Flechard et al. (2007); Kanerva et al. (2007); Kasimir and Klemedtsson (unpubl.); Maljanen et al. (2007b), Virkajärvi et al. (2010); Perälä et al. (2006); Petersen (1999, 2006); Regina et al. (2007); Syväsalo et al. (2004, 2006); Soussana et al. (2007). d Data from Ambus et al. (2001); Kasimir Klemedtsson and Klemedtsson (1997); Klemedtsson et al. (1997); Lagergren et al. (2008); Lindroth et al. (1998, 2007); Maljanen et al. (2006a,b, 2010b); Markkanen et al. (2001); Pihlatie et al. (2005, 2007); Pilegaard et al. (2003, 2006); Saari et al. (1998, 2004, 2005); Suni et al. (2003); Valentini et al. (2000); Yu et al. (2008); Zha et al. (2007).
}

in the emission of $13.9 \mathrm{~g} \mathrm{CO}_{2} \mathrm{~m}^{-2}$, which accounted for $14 \%$ of the annual $\mathrm{CO}_{2}$ emission (Åberg et al., 2004). The study of Duchemin et al. (2006) suggests that the episodic springtime $\mathrm{CH}_{4}$ and $\mathrm{CO}_{2}$ emissions from Canadian reservoirs at spring ice melt are a small but non-negligible component of the annual GHG budgets of these sites.

\subsubsection{Importance of turbines and downstream river}

There is only one experimental study on the importance of outgassing in turbines/spillways and downstream river in the total $\mathrm{CO}_{2}$ emissions in boreal reservoirs and none on the degassing of $\mathrm{CH}_{4}$ and $\mathrm{N}_{2} \mathrm{O}$. Roehm and Tremblay (2006) concluded that the degassing of $\mathrm{CO}_{2}$ from the turbines accounted for only $<1 \%$ to $7 \%$ of the $\mathrm{CO}_{2}$ emissions occurring through the surface in LaGrande-2 and LaGrande-3 reservoirs in Quebec, Canada. It should be stressed here that the degassing emissions downstream of the dam can play an important role in the $\mathrm{CH}_{4}$ emissions from some tropical reservoirs (Kemenes et al., 2007).

\section{Discussion}

\subsection{General}

A large number of GHG measurements have been carried out in the Nordic countries for managed peatlands. However, in some land-use options, measurements have been limited to only few sites with a short measuring period. Therefore the presented values of the GHG emissions are more like snapshots because the gas fluxes have high spatial and temporal variation, emissions depend on several factors e.g. on weather conditions, drainage intensity (i.e. WT depth), the type of original peatland drained, and the land use history. For some land-use options, the data is totally lacking or scarce. In particular, the carbon balance of forested sites, i.e. peatland forests, afforested peat extraction sites and afforested croplands is poorly studied. However, this paper gives a rough range of $\mathrm{GHG}$ emissions based on the data available in the Nordic countries for these different land-use options of peat soils.

An accurate up-scaling of GHG fluxes of each land-use class requires enough experimental sites to cover the internal variation within the groups. There is certainly a risk that this variation is not fully covered within the available data. There is also a lack in the background information regarding the studied sites. For example, peat characteristics (trophy of the site, origin of the peat, $\mathrm{pH}, \mathrm{C} / \mathrm{N}$ ratio, WT depth) and the land use history are rarely reported, which makes comparison between various land-use options difficult. The relationships between peat characteristics and emissions could have been more informative if this background information were available from all sites (Figs. 2 and 3). 


\subsection{Flux measurement methods}

GHG flux data from different land-use categories discussed in this review has been obtained with different methods and varying measurement periods. Most of the $\mathrm{N}_{2} \mathrm{O}$ and $\mathrm{CH}_{4}$ flux studies have been carried out with static chamber techniques, whereas $\mathrm{CO}_{2}$ balance is studied using either $\mathrm{EC}$ or chamber methods. The results obtained with these methods may not be totally comparable (e.g. Clement et al., 1995; Lohila et al., 2007b, 2008; Pihlatie et al., 2009). These methods have both advantages and disadvantages. Chambers cover only a small area of the soil surface and installation of collars for the chamber measurement may disturb the root systems of the plants. The measuring frequency is generally low (e.g. weekly-biweekly) if an automatic chamber system is not applied. The installation of the chambers for the measurements may disturb the gas concentration in soil, causing an extra release of gas from soil. On the other hand, nonlinear changes in the gas concentration in chambers, especially with a long incubation time, causes deviation in the real flux rate if a linear approach is used to calculate the flux rate from the change in gas concentration with time (Kroon et al., 2008; Kutzbach et al., 2007; Rochette and EriksenHamel, 2008). A benefit with chambers is that various functional surfaces within a small area can be measured whereas the EC method integrates flux for a large area without separating the functional surfaces in the footprint area (e.g. Alm et al., 2007). The EC technique allows minimal disturbance of the microenvironment being studied and can be used for tall vegetation like forested ecosystems. The EC method can provide continuous data when the gap filling of missing data is used (e.g. Lohila et al., 2007b).

\subsection{Measurement periods}

The length of the study periods applied varies from a few months (growing season) to several years. In many studies, winter measurements are scarce or totally missing. In some publications, the emissions measured only during a growing season are reported as annual emissions. Therefore, the annual emissions are biased under these conditions and if winter emissions are assumed to be zero. The emissions of all gases during winter can vary but in most cases the winter emissions contribute significantly to the annual gas budget (e.g. Alm et al., 1997, 1999b; Lohila et al., 2007b; Regina et al., 2004). In particular $\mathrm{N}_{2} \mathrm{O}$ emissions during the period with snow and soil frost can contribute even more than $80 \%$ of the annual $\mathrm{N}_{2} \mathrm{O}$ emissions from e.g. agricultural soils or forested peat soils (Alm et al., 1999b; Mäkiranta et al., 2007; Maljanen et al., 2004, 2009, 2010a). $\mathrm{N}_{2} \mathrm{O}$ produced in frozen soil can accumulate continuously in soil if an ice layer on top of the soil acts as a diffusion barrier (Koponen et al., 2004; Maljanen et al., 2007b, 2009). High amounts of accumulated $\mathrm{N}_{2} \mathrm{O}$ can be then released during a short thawing period, in addition to new $\mathrm{N}_{2} \mathrm{O}$ produced in denitrification
(Wagner-Riddle et al., 2008). Depending on the soil properties, high $\mathrm{N}_{2} \mathrm{O}$ bursts may also occur during soil freezing (Maljanen et al., 2007b, 2009, 2010a). If these high emission periods are missed, the annual emission can be greatly underestimated. Also, $\mathrm{CO}_{2}$ is emitted from peat soils during winter (Alm et al., 1999b) and the winter emission can be a significant part of the annual budget, about $20 \%$ of the annual $\mathrm{CO}_{2}$ release from the peat (Alm et al., 1999b). Alm et al. (1999b) estimated that the average winter $\mathrm{CH}_{4}$ emission from boreal undrained bogs and fens was $22 \%$ of the annual $\mathrm{CH}_{4}$ emission. On drained peatlands which consume atmospheric $\mathrm{CH}_{4}$, the small $\mathrm{CH}_{4}$ uptake can continue also during winter (Mäkiranta et al., 2007; Maljanen et al., 2003a, 2010a). However, the net fluxes of $\mathrm{CH}_{4}$ on drained peatlands during winter period are usually insignificant compared to the growing season.

\subsection{Gaps in the knowledge of GHG emissions from peat soils}

The gas dynamics of organic agricultural soils have been studied most intensively (data from about 40 sites in the Nordic countries) probably because the gas fluxes of these soils have been identified as having great atmospheric importance. These soils are also methodologically easier to measure than soils with tall vegetation (e.g. forest). Winter emissions from agricultural soils are also well documented. The long term use of peat soils for agriculture induces C-loss from soil, which reduces peat depth. If the peat layer is shallow the soils turn gradually to less organic mull or finally to mineral soils (Myllys, 1996). The effect of this change on GHG emissions with time is not known.

In addition, emissions from the drainage ditches have not been reported for any agricultural soils in the Nordic countries. Emissions from ditches have been reported only for some forestry drained peat soils or peat extraction sites (Sundh et al., 2000; Minkkinen et al., 1997). Emissions per unit area from the drainage ditches on agricultural peat soils can be higher than emissions e.g. from lakes (Schrier-Uijl et al., 2010) and may have importance in the total GHG emissions from agricultural soils.

The area of afforested croplands is increasing, and therefore more information from this land-use option is needed. GHG balance of afforested peat soils can depend on the age of afforestation and tree species. The whole rotation period, including harvesting, should be considered when comparing afforestation and other possible land-use options of drained peat soils. GHG balance of peatlands drained for forestry have been studied including ground vegetation in the measurements. However, for forested or afforested sites the data on net $\mathrm{CO}_{2}$ exchange including also the tree layer is sparse. Due to the lack of measured data, the $\mathrm{C}$ balance has been estimated using changes in the soil carbon pool and estimating C sequestration in tree stands (Minkkinen et al., 2001; Klemedtsson et al., 2007). 
The restoration of drained peat soils has been carried out on a small scale in the Nordic countries. The gas dynamics of the restoration of forestry drained peatlands have been studied in Finland in one geographical location. However, the area of restored peatlands may increase in the future especially in Iceland (UNFCCC, 2008; Ministry for the Environment, 2007). There, large areas of drained organic soils are outside agriculture and are used mainly for grazing, often with low intensity. Restoring these areas seems to be a promising option to reduce GHG emissions. More studies are required to evaluate the effects when sites with different land use history and soil properties are restored. Annually, large areas (mainly in Finland) of peat extraction sites are abandoned and therefore more information on GHG emissions related to various after-use options of peat extraction sites is required. Crop production (energy crops such as perennial reed canary grass) could be a promising option to mitigate $\mathrm{CO}_{2}$ losses from drained peat soil (Shurpali et al., 2010), but there is a need for more studies covering various crops and sites with variable peat characteristics and hydrological conditions.

\subsection{Net emissions from water reservoirs}

The present day GHG emissions from reservoirs can be called "gross emissions" (postflood), conventionally meaning those GHG emissions on a smaller scale occurring though the reservoir surface and sometimes from turbine structures in the vicinity of dams. On a larger scale, these emissions may include additional emissions from the downstream river directly attributable to the existence of a reservoir upstream. However, the knowledge of how the reservoirs potentially affect the original (preflood) GHG balance of a flooded landscape has highlighted the need to introduce a term "net emissions". Net emissions mean real changes in the watershed-scale GHG (and carbon) balances (and possibly stocks) caused by a reservoir. To estimate this, the largescale preflood GHG of both the reservoir area and the whole watershed from upstream trough the river down to estuary need to be known, and the "net" is defined as the difference between the postflood and preflood situation. To complete the picture, possible changes in the ecosystem $\mathrm{C}$ storages (vegetation, soils) need to be evaluated.

Determination of net emissions, even based on inventorying of flooded land and GHG flux data from similar ecosystems, could result in unexpected results. In Finnish reservoirs, Lokka and Porttipahta, pre- and postflood fluxes have been calculated for $\mathrm{CH}_{4}$ and $\mathrm{N}_{2} \mathrm{O}$ (Huttunen and Martikainen, 2005a,b). Based on results from previous studies (e.g. Kelly et al., 1994; Duchemin et al., 1995) we assumed that flooding would lead to higher $\mathrm{CH}_{4}$ emissions. Surprisingly, those reservoirs have lowered rather than increased the $\mathrm{CH}_{4}$ release in their area, although the $\mathrm{CH}_{4}$ release from Lokka was mostly high. This was because the minerotrophic peatlands flooded by these reservoirs originally had high
$\mathrm{CH}_{4}$ emissions. For $\mathrm{N}_{2} \mathrm{O}$, changes in the landscape-scale fluxes were not remarkable, since the fluxes both before and after the reservoirs were constructed, were low. In Swedish reservoirs, the change of $\mathrm{CO}_{2}$ fluxes of the landscape was relatively small and the landscape was alpine upland forest. The Icelandic reservoir established on peatland and upland mineral soils was a considerable source of $\mathrm{CO}_{2}$, whereas the impounded ecosystems were close to zero or a small source (Óskarsson and Guðmundsson, 2008a).

An interesting question is what happens to the carbon stocks in flooded landscapes. Finnish reservoirs have been estimated to have drowned tens of $\mathrm{Tg}$ of carbon. Based on the measurements at Lokka, the contribution of fresh carbon in the GHG production is most probably high and the fate of flooded peat deposits unknown (Huttunen et al., 2002b). However, a recent tracer study suggested that the new sedimentation in a boreal reservoir is dominated by autochthonous organic carbon or by carbon eroded in other parts of the reservoirs (Houel et al., 2006). These findings indicate that the recent production of fresh organic matter fuels the GHG production within the systems. The continuing GHG release from a reservoir does not then necessarily lead to major losses from the flooded $\mathrm{C}$ deposits. Much needs to be done to be able to identify all sources of GHG production in the reservoirs and their environment, before real net emissions can be assessed.

\subsection{Conclusions}

Agriculture is climatically the most unfavorable land-use option for managed peat soils when considering GHG fluxes from the biological processes in soil. The mean GHG emissions from organic agricultural soils are higher than those from mineral agricultural soils. Drainage, ploughing and fertilization cause a high decomposition rate of peat leading to high $\mathrm{CO}_{2}$ and $\mathrm{N}_{2} \mathrm{O}$ emissions. After drainage, $\mathrm{CH}_{4}$ emissions decrease and hence, it has been considered to be a minor part of the total GWP of peat soils used for agriculture. Soils with perennial grasses seem to emit less $\mathrm{CO}_{2}$ and $\mathrm{N}_{2} \mathrm{O}$ than soils which are regularly ploughed, e.g. for cultivation of cereals. The mitigation of GHG emissions from peat soils used for agriculture is challenging. Afforestation could lead to lower $\mathrm{CO}_{2}$ losses but $\mathrm{N}_{2} \mathrm{O}$ emissions may remain similar to those from cultivated peat soils for decades. However, there are only a few studies on the net $\mathrm{CO}_{2}$ exchange of afforested agricultural soils and more data on the GHG balance after afforestation at a whole ecosystem scale is required to make any firm conclusions about the atmospheric impact of this land-use option. Evaluation of whole rotation periods and the inclusion of the GHG effect of harvested wood products are also needed to better understand the long term effects of afforestation.

In addition to agricultural soils, peat extraction sites are net GHG emitters. Peat extraction for fuel is a very drastic land use option. After peat extraction has ended, restoration, 
afforestation or growing of crops may take place, but the GHG emissions from these land use options are still poorly known. If the new biomass dryer method is used in the future it may lower GHG emissions from peat extraction because no pre-drying phase is needed. However, there is no research evidence regarding the after use of such peat extraction sites.

Peat soils drained for forestry and reed canary grass cultivation on abandoned peat extraction sites seem to be climatically more favorable than those used for agriculture. In these cases, carbon loss from the drained peat soil is compensated by the accumulation of $\mathrm{C}$ in aboveground and belowground biomass and in soil. However, the biomass $\mathrm{C}$ is mostly returned back into the atmosphere when these crops are harvested. There is very little experimental data to show the possible atmospheric benefits of perennial crops on organic soils. Furthermore, the fate of the native peat carbon is poorly known. Some ecosystems may lose soil carbon even though there is an increase in the biomass carbon.

Peat soils drained for agriculture have been studied more intensively than the other land-use options. $\mathrm{CH}_{4}$ and $\mathrm{N}_{2} \mathrm{O}$ fluxes from forested peatlands are also studied intensively in Finland and Sweden, where forestry on peat soils has been a common practice. However, measured $\mathrm{CO}_{2}$ balances are scarce. More data on the net $\mathrm{CO}_{2}$ exchange is also required for the other afforested peat soils, especially for afforested peat extraction sites where no $\mathrm{CO}_{2}$ exchange data is available. In addition, the fate of soil carbon is poorly known.

Even if drainage reduces $\mathrm{CH}_{4}$ emissions, ditches may remain as sources of $\mathrm{CH}_{4}$. This data is available only from a few sites and emissions from drainage ditches from e.g. agricultural soils are not known. Because these emissions can potentially be a significant part of the total annual GHG budget, as in peat extraction areas, they should be studied more intensively also from the other drained peatlands.

Large emissions of GHG's have been detected from reservoirs where peatlands have been flooded. Conversely, the net effects of flooding can, in some cases, decrease $\mathrm{CH}_{4}$ emission compared to previous land use. Studies on the origin of the emitted GHG's indicate that the emissions may be mostly driven by fresh carbon rather than the impounded C-stocks.

Restoring of drained wetlands is believed to be an effective measure to sequester carbon as peat, but there is a need to determine the long term effect on the balance of all three GHG's. If the present natural state of the undisturbed peatlands is not a $\mathrm{C}$ sink, as seems to be the case with the Nordic ombrotrophic peatlands, the restoration measures are unlikely to lead to net $\mathrm{C}$ sequestration. A natural baseline is therefore always needed when the restoration measures are evaluated. The natural situation or the most successful restoration will lead to lower GHG emissions, compared to drained peatlands, even though these sites remain small sources.
Acknowledgements. The work was done by funding of NECC (The Nordic Centre for Studies of Ecosystem Carbon Exchange and its Interactions with the Climate System) and The Academy of Finland FiDi Pro Programme 127456. Jyrki Hytönen, Arne Grønlund, Kerstin Berglund, Leif Klemedtsson and Åsa Kasimir Klemedtsson are thanked for providing data for the manuscript and Narasinha Shurpali is thanked for valuable comments. This article is dedicated to a memory of our colleague and co-author, MSc Jari T. Huttunen, who suddenly passed away during the writing process of this work.

Edited by: H. Lankreijer

\section{References}

Åberg, J., Bergström, A.-K., Algesten, G., Söderback, K., and Jansson, M.: A comparison of the carbon balances of a natural lake (L. Östräsket) and a hydroelectric reseroir (L. Skinnmuddselet) in nothern Sweden, Water Res., 38, 531-538, 2004.

Ahlholm, U. and Silvola, J.: Turvetuotannon ja turpeen käytön osuus maapallon ja Suomen hiilitaseessa, Ministry of Trade and Industry, Ser. D, 183, 1-57, 1990.

Alm, J., Talanov, A., Saarnio, S., Silvola, J., Ikkonen, E., Aaltonen, H., Nykänen, H., and Martikainen, P. J.: Reconstruction of the carbon balance for microsites in a boreal oligotrophic pine fen, Oecologia, 110, 423-431, 1997.

Alm, J., Schulman, L., Walden, J., Nykänen, H., Martikainen, P. J., and Silvola, J.: Carbon balance of a boreal bog during a year with an exceptionally dry summer, Ecology, 80, 161-174, 1999a.

Alm, J., Saarnio, S., Nykänen, H., Silvola, J., and Martikainen, P. J.: Winter $\mathrm{CO}_{2}, \mathrm{CH}_{4}$ and $\mathrm{N}_{2} \mathrm{O}$ fluxes on some natural and drained boreal peatlands, Biogeochemistry, 44, 163-186, 1999b.

Alm, J., Shurpali, N. J., Minkkinen, K., Aro, L., Hytönen, J., Laurila, T., Lohila, A., Maljanen, M., Mäkiranta, P., Penttilä, T., Saarnio, S., Silvan, N., Tuittila, E.-S. and Laine, J.: Emission factors and their uncertainty for the exchange of $\mathrm{CO}_{2}, \mathrm{CH}_{4}$ and $\mathrm{N}_{2} \mathrm{O}$ in Finnish managed peatlands, Boreal Environ. Res., 12, 191-209, 2007.

Ambus, P.: Nitrous oxide production by denitrification and nitrification in temperate forest, grassland and agricultural soils, Eur. J. Soil Sci., 49, 495-502, 1998.

Ambus, P., Jensen, J. M., Priemé, A., Pilegaard, K., and Kjøller, A.: Assessment of $\mathrm{CH}_{4}$ and $\mathrm{N}_{2} \mathrm{O}$ fluxes in a Danish beech (Fagus sylvatica) forest and an adjacent $\mathrm{N}$-fertilised barley (Hordeum vulgare) field: effects of sewage sludge amendments, Nutr. Cycl. Agroecosys., 60, 15-21, 2001.

Aurela, M., Laurila, T., Tuovinen, J.-P.: The timing of snow melt controls the annual $\mathrm{CO}_{2}$ balance in a subarctic fen, Geophys. Res. Lett., 31, L16119, doi:10.1029/2004GL020315, 2004.

Aurela, M., Riutta, T., Laurila, T., Tuovinen, J.-P., Vesala, T., Tuittila, E.-S., Rinne, J., Haapanala, S., and Laine, J.: $\mathrm{CO}_{2}$ exchange of a sedge fen in southern Finland - the impact of a drought period, Tellus B, 59, 826-837, 2007.

Bäckstrand, K., Crill, P. M., Jackowicz-Korczyñski, M., Mastepanov, M., Christensen, T. R., and Bastviken, D.: Annual carbon gas budget for a subarctic peatland, Northern Sweden, Biogeosciences, 7, 95-108, doi:10.5194/bg-7-95-2010, 2010.

Baldocchi, D., Hicks, B., and Meyers, T.: Measuring biosphereatmosphere exchanges of biologically related gases with micrometeorological methods, Ecology, 69, 1331-1340, 1988. 
Berglund, Ö. and Berglund, K.: Odlad organogen jord i Sverige 2003: Areal och grödfördelning uppskattad med hjälp av digitaliserade databaser, Rapport 7 (Sveriges lantbruksuniversitet, Institutionen för markvetenskap, Avdelningen för hydroteknik), http://pub-epsilon.slu.se/197/, last access: 13 September 2010, 2008.

Berglund, Ö. and Berglund, K.: Distribution and cultivation intensity of agricultural peat and gyttja soils in Sweden and estimation of greenhouse gas emissions from cultivated peat soils, Geoderma, 154, 173-180 doi:10.1016/j.geoderma.2008.11.035, 2010.

Bergström, A.-K., Algesten, G., Sobek, S., Tranvik, L., and Jansson, $\mathrm{M}$.: Emission of $\mathrm{CO}_{2}$ from hydroelectric reservoirs in northern Sweden, Arch. Hydrobiol., 159, 25-42, 2004.

Björnsson, H., Sveinbjörnsdóttir, Á. E., Daníelsdóttir, A. K., Snorrason, Á., Sigurðsson, B. D., Sveinbjörnsson, E., Viggósson, G., Sigurjónsson, J., Baldursson, S., Porvaldsdóttir, S., and Jónsson, T.: Hnattrænar loftslagsbreytingar og áhrif peirra á Íslandi Skýrsla vísindanefndar um loftslagsbreytingar, Ministry for the Environment, Reykjavik, 121, 2008.

Bodaly, R. A., Beaty, K. G., Hendzel, L. H., Majewski, A. R., Paterson, M. J., Rolfhus, K. R., Penn, A. F., St. Louis, V. L., Hall, B. D., Matthews, C. J. D., Cherewyk, K. A., Mailman, M., Hurley, J. P., Schiff, S. L., and Venkiteswaran, J. J.: Experimenting with hydroelectric reservoirs, Environ. Sci. Technol., 38, 346A-352A, 2004.

Chatskikh, D. and Olesen, J.: Soil tillage enhanced $\mathrm{CO}_{2}$ and $\mathrm{N}_{2} \mathrm{O}$ emissions from loamy sand soil under spring barley, Soil Till. Res., 97, 5-18, 2007.

Clement, R. J., Verma, S. B., and Verry, E. S.: Relating chamber measurements to eddy correlation measurements of methane flux, J. Geophys. Res., 100, 21047-21056, 1995.

Djurhuus, S., Krogh, L., and Greve, M. H.: Estimates of the carbon stocks in Danish mires, Icel. Agric. Sci., 18, 11-20, 2005.

Duchemin, É., Lucotte, M., Canuel, R., and Chamberland, A.: Production of the greenhouse gases $\mathrm{CH}_{4}$ and $\mathrm{CO}_{2}$ by hydroelectric reservoirs of the boreal region, Global Biogeochem. Cy., 9, 529540, 1995

Duchemin, É., Lucotte, M., Canuel, R., and Soumis, N.: First assessment of methane and carbon dioxide emissions from shallow and deep zones of boreal reservoirs upon ice break-up, Lake Reserv. Manage., 11, 9-19, 2006.

Eriksson, J., Nilsson, I., and Simonsson, M.: Wiklanders marklära, Studentliteratur, Lund, Sweden, 42-50, 2005.

Flechard, C. R., Ambus, P., Skiba, U., Rees, R. M., Hensen, A., van Amstel, A., van den Pol-van Dasselaar, A., Soussana, J.-F., Jones, M., Clifton-Brown, J., Raschi, A., Horvath, L., Neftel, A., Jocher, M., Ammann, C., Leifeld, J., Fuhrer, J., Calanca, P., Thalman, E., Pilegaard, K., Di Marco, C., Campbell, C., Nemitz, E., Hargreaves, K. J., Levy, P. E., Ball, B. C., Jones, S. K., van de Bulk, W. C. M., Groot, T., Blom, M., Domingues, R., Kasper, G., Allard, V., Ceschia, E., Cellier, P., Laville, P., Henault, C., Bizouard, F., Abdalla, M., Williams, M., Baronti, S., Berretti, F., and Grosz, B.: Effects of climate and management intensity on nitrous oxide emissions in grassland systems across Europe, Agr. Ecosyst. Environ., 121, 135-152, 2007.

Garðarsson, A., Magnússon, B., Thorleifsson, E. Ó., Óskarsson, H., Hilmarsson, J. Ó., Lund, S., Thráinsson, N. Á., and Baldursson, T.: Endurheimt votlendis 1996-2006, Report by the Icelandic
Ministry for Agriculture on wetland restoration in the period 1996-2006, Landbúnaðarráðuneytið, Reykjavík, 27 p., 2006.

Gorham, E.: Northern peatlands: Role in the carbon cycle and probable responses to climatic warming, Ecol. Appl., 1, 182-195, 1991.

Grønlund, A., Sveistrup, T. E., Søvik, A. K., Rasse, D. P., and Kløve, B. : Degradation of cultivated peat soils in Norway based on field scale $\mathrm{CO}_{2}, \mathrm{~N}_{2} \mathrm{O}$ and $\mathrm{CH}_{4}$ emission measurements, Arch. Agron. Soil Sci., 52, 149-159, 2006.

Grønlund, A., Hauge, A., Hovde, A., and Rasse, D. P.: Carbon loss estimates from cultivated peat soils in Norway: a comparison of three methods, Nutr. Cy. Agroecos., 81, 157-167, 2008.

Guðmundsson, J. and Óskarsson, H.: Summaries of GHG measurement studies. UNESCO/IHA Greenhouse Gas Research Project, Measurement Specification Workshop, London, UK, 12-14 November, 2008.

Guerin, F., Abril, G., Serça, D., Delon, C., Richard, S., Delmas, R., Tremblay, A., and Varfalvy, L.: Gas transfer velocities of $\mathrm{CO}_{2}$ and $\mathrm{CH}_{4}$ in a tropical reservoir and its river downstream, J. Mar. Syst., 66, 161-172, 2006.

Haapala, J. K., Mörsky, S. K., Saarnio, S., Rinnan, R., Suokanerva, H., Kyrö, E., Latola, K., Martikanen, P. J., Holopainen, T., and Silvola, J.: Carbon dioxide balance of a fen ecosystem in northern Finland under elevated UV-B radiation, Global Change Biol., 15, 943-954, 2009.

Hånell, B.: Torvtäckta marker, dikning och sumpskogar i Sverige, Skogsfakta, inventering och ekonomi (Sveriges lantbruksuniversitet) nr 22, 1990.

Harby, A., Brakstad, O. G., and Sundt, H.: Greenhouse gas (GHG) emissions from hydropower reservoirs, Net emission rates calculated for Follsjø reservoirs, Project Memo. SINTEF Energy Research, Trondheim, Norway, 12 p., 2006.

Hargreaves, K. J., Milne, R., and Cannell, M. G. R.: Carbon balance of afforested peatland in Scotland, Forestry, 76, 299-317, 2003.

Hellsten, S. K., Virtanen, M. O., Nenonen, O. S., Kinnunen, K. A., and Riihimäki, J. M.: Relative importance of internal sources of phosphorus and organic matter in northern Finnish reservoirs, Water Sci. Technol., 28, 85-94, 1993.

Hjertestedt, H.:. De organogena odlingsjordarnas beskaffenhet i olika län med avseende på torvslag, förmultningsgrad och reaktion samt innehåll av kalk och kväve, kali och fosforsyra, organisk substans, seskvioxider och svavelsyra, Svenska Vall- och Mosskulturföreningens Kvartalsskrift, 8, 255-277, 1946.

Höper, H., Augustin, J., Cagampan, J. P., Drösler, M., Lundin, L., Moors, E., Vasander, H., Waddington, J. M., and Wilson, D.: Restoration of peatlands and greehouse gas balances, in: Peatlands and Climate Change, edited by: Starck, M., International Peat Society, Saarijärvi, Finland, 182-210, 2008.

Huttunen, J., Nykänen, H., Turunen, J., Nenonen, O., and Martikainen, P. J.: Fluxes of nitrous oxide on natural peatlands in Vuotos, an area projected for a hydroelectric reservoir in northern Finland, Suo, 53, 87-96, 2002a.

Huttunen, J. T., Väisänen, T. S., Hellsten, S. K., Heikkinen, M., Nykänen, H., Jungner, H., Niskanen, A., Virtanen, M. O., Lindqvist, O. V., Nenonen, O. S., and Martikainen, P. J.: Fluxes of $\mathrm{CH}_{4}, \mathrm{CO}_{2}$, and $\mathrm{N}_{2} \mathrm{O}$ in hydroelectric reservoirs Lokka and Porttipahta in the northern boreal zone in Finland, Global Biogeochem. Cy., 16, 1003, doi:10.1029/2000GB001316, 2002 b. 
Huttunen, J. T., Nykänen, H., Martikainen, P. J., and Nieminen, M.: Fluxes of nitrous oxide and methane from drained peatlands following forest clear-felling in southern Finland, Plant Soil, 255, 457-462, 2003.

Huttunen, J. T. and Martikainen, P. J.: Long-term effects of boreal reservoirs on the landscape-atmosphere $\mathrm{N}_{2} \mathrm{O}$ exchange, Verh. Internat. Verein. Limnol., 29, 607-611, 2005a.

Huttunen, J. T. and Martikainen, P. J.: Long-term net methane release from Finnish hydro reservoirs, in: Global warming and Hydroelectric Reservoirs, edited by: Santos, M. A. and Rosa, L. P., Proceedings of International Seminar on Greenhouse Fluxes from Hydro Reservoirs and Workshop on Modeling Greenhouse Gas Emissions from Reservoir at Watershed Level, Rio de Janeiro, Brazil, COPPE/UFRJ and Electrobrás, 8-12 August 2005, 125-135, 2005b.

Houel, S., Louchouarn, P., Lucotte, M., Canuel, R., and Ghaleb, B.: Translocation of soil organic matter following reservoir impoundment in boreal systems: Implications for in situ productivity, Limnol. Ocean., 51, 1497-1513, 2006.

Hyvönen, N. P., Huttunen, J. T., Shurpali, N. J., Tavi, N. M., Repo, M. E., and Martikainen, P. J.: Fluxes of nitrous oxide and methane on an abandoned peat extraction site: Effect of reed canary grass cultivation, Bioresource Technol., 100, 4723-4730, 2009.

Janzen, H. H.: Carbon cycling in earth systems - a soil science perspective, Agr. Ecosyst. Environ., 104, 399-417, 2004.

Kanerva, T., Regina, K., Rämö, K., Ojanperä, K., and Manninen, S.: Fluxes of $\mathrm{N}_{2} \mathrm{O}, \mathrm{CH}_{4}$ and $\mathrm{CO}_{2}$ in a meadow ecosystem exposed to elevated ozone and carbon dioxide from three years, Environ. Pollut., 145, 818-828, 2007.

Kasimir Klemedtsson, ̊., Weslien, P., and Klemedtsson, L.: Methane and nitrous oxide fluxes from a farmed Swedish Histosol, Eur. J. Soil Sci., 60, 321-331, 2009.

Kasimir Klemedtsson, $\AA$ and Klemedtsson, L.: Methane uptake in Swedish forest soil in relation to liming and extra N-deposition, Biol. Fert. Soils, 25, 296-301, 1997.

Kasimir Klemedtsson, A., Klemedtsson, L., Berglund, K., Martikainen, P. J., Silvola, J., and Oenema, O.: Greenhouse gas emissions from farmed organic soils: a review, Soil Use Manage., 13, 245-250, 1997

Keller, M. and Stallard, R. F.: Methane emission by bubbling from Gatun Lake, Panama, J. Geophys. Res., 99, 8307-8319, 1994.

Kelly, C. A., Rudd, J. W. M., Bodaly, R. A., Roulet, N. P., St. Louis, V. L., Heyes, A., Moore, T. R., Schiff, S., Aravena, R., Scott, K. J., Dyck, B., Harris, R., Warner, B., and Edwards, G.: Increases in fluxes of greenhouse gases and methyl mercury following flooding of an experimental reservoir, Environ. Sci. Technol., 31, 1334-1344, 1994.

Kemenes, A., Forsberg, B. R., and Melack, J. M.: Methane release below a tropical hydroelectric dam, Geophys. Res. Lett., 34, L12809, doi:10.1029/2007GL029479, 2007.

Kivimäki, S., Yli-Petäys, M., and Tuittila, E.-S.: Carbon sink function of sedge and Sphagnum patches in a restored cutaway peatland: increased functional diversity leads to higher production, Appl. Ecol., 45, 921-929, doi:10.1111/j.13652664.2008.01458.x, 2008.

Klemedtsson, L., Jansson, P.-E., Gustafsson, D., Karlberg, L., Weslien, P., von Arnold, K., Ernfors, M., Langvall, O., and Lindroth, A.: Bayesian calibration method used to elucidate carbon turnover in forest on drained organic soil, Biogeochemistry, 89, 61-79, doi:10.1007/s10533-007-9169-0, 2007.

Klemedtsson, L., von Arnold, K., Weslien, P., and Gundersen, P.: Soil $\mathrm{CN}$ ratio as a scalar parameter to predict nitrous oxide emissions, Global Change Biol., 11, 1142-1147, 2005.

Klemedtsson, L., Kasimir Klemedtsson, A., Moldan, F., and Weslien, P.: Nitrous oxide emission from Swedish forest soils in relation to liming and simulated increased N-deposition, Biol. Fert. Soils, 25, 290-295, 1997.

Kløve, B., Sveistrup, T. E., and Hauge, A.: Leaching of nutrients and emission of greenhouse gases from peatland cultivation at Bodin, Northern Norway, Geoderma, 154, 219-232, 2010.

Komulainen, V.-M., Nykänen, H., Martikainen, P. J., and Laine, J.: Short-term effect of restoration on vegetation change and methane emissions from peatlands drained for forestry in southern Finland, Can. J. For. Res., 28, 402-411, 1998.

Komulainen, V.-M., Tuittila, E. S., Vasander, H., and Laine, J.: Restoration of drained peatlands in southern Finland: initial effects on vegetation change and $\mathrm{CO}_{2}$ balance, J Appl. Ecol., 36, 634-648, 1999.

Koponen, H. T., Flöjt, L., and Martikainen, P. J.: Nitrous oxide emissions from agricultural soils at low temperatures: a laboratory microcosm study, Soil Biol. Biochem., 36, 757-766, 2004.

Kroon, P. S., Hensen, A., van den Bulk, W. C. M., Jongejan, P. A. C., and Vermeulen, A. T.: The importance of reducing the systematic error due to non-linearity in $\mathrm{N}_{2} \mathrm{O}$ flux measurements by static chambers, Nutr. Cy. Agroecosys., 82, 175-186, 2008.

Kutzbach, L., Schneider, J., Sachs, T., Giebels, M., Nykänen, H., Shurpali, N. J., Martikainen, P. J., Alm, J., and Wilmking, M.: $\mathrm{CO}_{2}$ flux determination by closed-chamber methods can be seriously biased by inappropriate application of linear regression, Biogeosciences, 4, 1005-1025, doi:10.5194/bg-41005-2007, 2007.

Lagergren, F., Lindroth, A., Dellwik, E., Ibrom, A., Landkreijer, H., Launiainen, S., Mölder, M., Kolari, P., Pilegaard, K., and Vesala, T.: Biophysical controls on $\mathrm{CO}_{2}$ fluxes of three Northern forests based on long-term eddy covariance data, Tellus B, 60, 143-152, 2008.

Laine, J., Minkkinen, K., Sinisalo, J., Savolainen, I., and Martikainen, P. J.: Greenhouse Impact of a mire after drainage for forestry, in: Northern Forested Wetlands, Ecology and Management, edited by: Trettin, C. C., Jurgensen, M. F., Grigal, D. F., Gale, M. R., and Jeglum, J. K., CRC Lewis Publishers, Boca Raton, USA, 437-447, 1996.

Laurila, T., Lohila, A., Aurela, M., Tuovinen, J.-P., Thum, T., Aro, L., Laine, J., Penttilä, T., Minkkinen, K., Riutta, T., Rinne, J., Pihlatie, M., and Vesala, T.: Ecosystem-level carbon sink measurements on forested peatlands, in: Greenhouse Impacts of the Use of Peat and Peatlands in Finland, edited by: Sarkkola, S., Ministry of Agriculture and Forestry, 11a/2007, 38-40, 2007.

Le Mer, J. and Roger, P.: Production, oxidation, emission and consumption of methane by soils: A review, Eur. J. Soil Biol., 37, 25-50, 2001.

Liikanen, A., Huttunen, J. T., Karjalainen, S. M., Heikkinen, K., Väisänen, T. S., Nykänen, H., and Martikainen, P. J.: Temporal and seasonal changes in greenhouse gas emissions from a constructed wetland purifying peat mining runoff waters, Ecol. Eng., 26, 241-251, 2006. 
Lindroth, A., Grelle, A., and Moren, A.-S.: Long-term measurements of boreal forest carbon balance reveal large temperature sensitivity, Global Change Biol., 4, 443-450, 1998.

Lindroth, A., Klemedtsson, L., Grelle, A., Weslien, P., and Langwell, O.: Measurement of net ecosystem exchange, productivity and respiration in three spruce forests in Sweden shows unexpectedly large soil carbon losses, Biogeochemistry, 89, 43-60, 2007.

Lohila, A., Aurela, M., Regina, K., and Laurila, T.: Soil and ecosystem respiration in agricultural fields: effect of soil and crop type, Plant Soil, 251, 303-317, 2003.

Lohila, A., Aurela, M., Tuovinen, J.-P., and Laurila, T.: Annual $\mathrm{CO}_{2}$ exchange of a peat field growing spring barley or perennial forage, J. Geophys. Res., 109, D18116, doi:10.1029/2004JD004715, 2004.

Lohila, A., Laurila, T., Aro, L., Aurela, M., Tuovinen, J.-P., Laine, J., and Minkkinen, K.: Carbon dioxide exchange above a 30year-old Scots pine plantation established on organic-soil cropland, Boreal Environ. Res., 12, 141-157, 2007a.

Lohila, A., Aurela, M., Regina, K., Tuovinen, J.-P., and Laurila, T.: Wintertime $\mathrm{CO}_{2}$ exchange in a boreal agricultural peat soil, Tellus B, 59, 860-873, 2007b

Lohila, A.; Carbon dioxide exchange on cultivated and afforested boreal peatlands, Finnish Meteorological Institute Contributions 73, Yliopistopaino, Helsinki, PhD Thesis, 2008.

Lund, M., Lindroth, A., Christiansen, T. R., and Ström, L.: Annual $\mathrm{CO}_{2}$ balance of a temperate bog, Tellus B, 59, 804-811, 2007.

Mäkiranta, P., Hytönen, J., Aro, L., Maljanen, M., Pihlatie, M., Potila, H., Shurpali, N. J., Laine, J., Lohila, A., Martikainen, P. J., and Minkkinen, K.: Soil greenhouse gas emissions from afforested organic soil croplands and peat extraction peatlands, Boreal Environ. Res., 12, 159-175, 2007.

Maljanen, M., Martikainen, P. J., Walden, J., and Silvola, J.: $\mathrm{CO}_{2}$ exchange in an organic field growing barley or grass in eastern Finland, Global Change Biol., 7, 679-692, 2001a.

Maljanen, M., Hytönen, J., and Martikainen, P. J.: Fluxes of $\mathrm{N}_{2} \mathrm{O}$, $\mathrm{CH}_{4}$ and $\mathrm{CO}_{2}$ on afforested boreal agricultural soils, Plant Soil, 231, 113-121, 2001b.

Maljanen, M., Liikanen, A., Silvola, J., and Martikainen, P. J.: Methane fluxes on agricultural and forested boreal organic soils, Soil Use Manage., 19, 73-79, $2003 \mathrm{a}$.

Maljanen, M., Liikanen, A., Silvola, J., and Martikainen, P. J.: Nitrous oxide emissions from boreal organic soil under different land-use, Soil Biol. Biochem., 35, 689-700, 2003 b.

Maljanen, M., Liikanen, A., Silvola, J., and Martikainen, P. J.: Measuring $\mathrm{N}_{2} \mathrm{O}$ emissions from organic soils by closed chamber or soil/snow $\mathrm{N}_{2} \mathrm{O}$ gradient methods, Eur. J. Soil Sci., 54, 625-631, 2003c.

Maljanen, M., Komulainen, V.-M., Hytönen, J., Martikainen, P. J., and Laine, J.: Carbon dioxide, nitrous oxide and methane dynamics in boreal organic agricultural soils with different soil management, Soil Biol. Biochem., 36, 1801-1808, 2004.

Maljanen, M., Nykänen, H., Moilanen, M., and Martikainen, P. J.: Greenhouse gas fluxes of coniferous forest floors affected by wood ash fertilization, Forest Ecol. Manag., 237, 143-149, 2006a.

Maljanen, M., Jokinen, H., Saari, A., Strömmer, R., and Martikainen, P. J.: Methane and nitrous oxide fluxes, and carbon dioxide production in soil of boreal forest fertilized with wood ash and nitrogen, Soil Use Manage., 22, 151-157, $2006 \mathrm{~b}$.

Maljanen, M., Hytönen, J., Mäkiranta, P., Alm, J., Minkkinen, K., Laine, J., and Martikainen, P. J.: Greenhouse gas emissions from cultivated and abandoned organic croplands in Finland, Boreal Environ. Res., 12, 133-140, 2007a.

Maljanen, M., Kohonen, A.-R., Virkajärvi, P., and Martikainen, P. J.: Fluxes and production of $\mathrm{N}_{2} \mathrm{O}, \mathrm{CO}_{2}$ and $\mathrm{CH}_{4}$ in boreal agricultural soil during winter as affected by snow cover, Tellus B, 59, 853-859, 2007b.

Maljanen, M., Virkajärvi, P., Hytönen, J., Öquist, M., Sparrman, T., and Martikainen, P. J.: Nitrous oxide production in boreal soils with variable organic matter content at low temperature Üsnow manipulation experiment, Biogeosciences, 6, 2461-2473, doi:10.5194/bg-6-2461-2009, 2009.

Maljanen, M., Hytönen, J., and Martikainen, P. J.: Cold season nitrous oxide dynamics in a drained boreal peatland differ depending on land use practise, Can. J. For. Res., 40, 565-572, 2010a.

Maljanen, M., Alm, J., Martikainen, P. J., and Repo, T.: Expanded soil frost resulting from reduced snow cover increases nitrous oxide emissions from boreal forest soil, Boreal Environ. Res., 15, 34-42, $2010 b$.

Markkanen, T., Rannik, Ü., Keronen, P., Suni, T., and Vesala, T.: Eddy covariance fluxes over a boreal Scots pine forest, Boreal Environ. Res., 6, 65-78, 2001.

Martikainen, P. J., Nykänen, H., Crill, P., and Silvola, J.: The effect of changing water table on methane fluxes at two Finnish mire sites, Suo, 43, 237-240, 1992.

Martikainen, P. J., Nykänen, H., Crill, P., and Silvola, J.: Effect of a lowered water table on nitrous oxide fluxes from northern peatlands, Nature, 366, 51-53, 1993.

Martikainen, P. J., Nykänen, H., Alm, J., and Silvola, J.: Change in fluxes of carbon dioxide, methane and nitrous oxide due to forest drainage of mire sites of different trophy, Plant Soil, 168, 571-577, 1995a

Martikainen, P. J., Nykänen, H., Regina, K., Lehtonen, M., and Silvola, J.: Methane fluxes in a drained and forested peatland treated with different nitrogen compounds, in: Northern Peatlands in Global Climatic Change, edited by: Laiho, R., Laine, J., and Vasander, H., Proceedings of the International Workshop Held in Hyytiälä, Finland, Helsinki, 105-109, 1995b.

Ministry for the Environment: Iceland's Climate Change Strategy, 37, http://eng.umhverfisraduneyti.is/media/PDF_skrar/ Stefnumorkun_i_loftslagsmalum_enlokagerd.pdf, last access: 30 August 2008, 2007.

Minkkinen, K., Laine, J., Nykänen, H., and Martikainen, P. J.: Importance of drainage ditches in emissions of methane from mires drained for forestry, Can. J. For. Res., 27, 949-952, 1997.

Minkkinen, K., Laine, J., and Hökkä, H.: Tree stand development and carbon sequestration in drained peatland stands in Finland a simulation study, Silva Fenn., 35, 55-69, 2001.

Minkkinen, K., Penttilä, T., and Laine, J.: Tree stand volume as a scalar for methane fluxes in forestry-drained peatlands in Finland, Boreal Environ. Res., 12, 127-132, 2007.

Minkkinen, K. and Laine, J.: Long-term effect of forest drainage on the peat carbon stores of pine mires in Finland, Can. J. For. Res., 28, 1267-1275, 1998

Myllys, M.: Agriculture on peatlands, in: Peatlands in Finland, edited by: Vasander, H., Finnish Peatland Society, Helsinki, Finland, 1996. 
Myllys, M. and Sinkkonen, M.: Viljeltyjen turve-ja multamaiden pinta-ala ja alueellinen jakauma Suomessa, Suo, 55, 53-60, 2004.

Nielsen, O.-K., Lyck, E., Mikkelsen, M. H., Hoffmann, L., Gyldenkærne, S., Winther, M., Nielsen, M., Fauser, P., Thomsen, M., Plejdrup, M. S., Albrektsen, R., Hjelgaard, K., Vesterdal, L., Møller, I. S., and Baunbæk, L.: Denmark's National Inventory Report 2009 Emission Inventories 1990-2007 - Submitted under the United Nations Framework Convention on Climate Change, National Environmental Research Institute and Aarhus University, 2009.

Nilsson, M., Sagerfors, J., Buffan, I., Laudon, H., Eriksson, T., Grelle, A., Klemedtsson, L, Weslien, P., and Lindroth, A.: Contemporary carbon accumulation in a boreal oligotrophic minerogenic mire - a significant sink after accounting for all C-fluxes, Global Change Biol., 14, 2317-2332, 2008.

NN: Mótaka og mómýrar, 2. Grein í Lesbók Morgunblaðsins, 31. október 1965, Morgunblaðið, 35. tölubl, 1965.

Norwegian Pollution Control Authority: Greenhouse Gas Emission 1990-2007, National Inventory Report 2009, TA 2507, Norway, 2009.

Nykänen, H., Alm, J., Lång, K., Silvola, J., and Martikainen, P. J.: Emissions of $\mathrm{CH}_{4}, \mathrm{~N}_{2} \mathrm{O}$ and $\mathrm{CO}_{2}$ from a virgin fen and a fen drained for grassland in Finland, J. Biogeogr., 22, 351-357, 1995.

Nykänen, H., Silvola, J., Alm, J., and Martikainen, P. J.: Fluxes of greenhouse gases $\mathrm{CH}_{4}, \mathrm{CO}_{2}$ and $\mathrm{N}_{2} \mathrm{O}$ on some peat mining areas in Finland, in: Northern Peatlands in Global Climatic Change, edited by: Laiho, R., Laine, J., and Vasander, H., Proceedings of the International Workshop Held in Hyytiälä, Finland, Publication of the Academy of Finland, Helsinki, 1/96, 141-147, 1996.

Nykänen, H., Alm, J., Silvola, J., Tolonen, K., and Martikainen, P. J.: Methane fluxes on boreal peatlands of different fertility and the effect of long term experimental lowering of the water table on flux rates, Global Biogeochem. Cy., 12, 53-69, 1998.

Nykänen, H., Heikkinen, J. E. P., Pirinen, L., Tiilikainen, K., and Martikainen, P. J.: Annual $\mathrm{CO}_{2}$ exchange and $\mathrm{CH}_{4}$ fluxes on a subarctic palsa mire during climatically different years, Global Biogeochem. Cy., 17, 1018, doi:10.1029/2002GB001861, 2003.

Óskarsson, H.: Icelandic Peatlands: Effects of Draining on Trace Gas Release. PhD Dissertation, Institute of Ecology, University of Georgia, Athens, Georgia, USA, 1998.

Óskarsson, H. and Guðmundsson, J.: Gróðurhúsaáhrif uppistöðulóna; Rannsóknir við Gilsárlón 2003-2006, Greenhouse gas emission from hydroreservoirs; Results from Gilsárlón 2003-2006, Landsvirkjun, LV-2008/028, 142, 2008 a.

Óskarsson, H. and Guðmundsson, J.: Methane emissions of a hydroelectric reservoir in northern Iceland, in: Greenhouse gases and aerosols: Interactions between northern ecosystems and climate, Conference given by the NECC and BACCI Nordic Centres of Excellence, Reykjavik, Iceland, 16-18 June, 2008b.

Paavilainen, E. and Päivänen, J.: Peatland Forestry, Ecology and Principles, Ecological Studies 111, Springer-Verlag, Berlin, Germany, 248 pp., 1995.

Petersen, H., Lundblad, M., Guðmundsson, J., Pingoud, K., Gyldenkaerne, S., Hylen, G., and Tuomainen, T.: Enhanced incentives for mitigation efforts in the Land Use, Land Use Change and Forestry sector in the next global climate change agreement, Nordic Council of Ministers report, TemaNord 553, 2009.
Petersen, S. O., Regina, K., Pöllinger, A., Rigler, E., Valli, L., Yamulki, S., Esala, M., Fabbri, C., Syväsalo, E., and Vinther, F. P.: Nitrous oxide emissions from organic and conventional crop rotations in five European countries, Agr. Ecosyst. Environ., 112, 200-206, 2006.

Petersen, S. O.: Nitrous oxide emissions from manure and inorganic fertilizers applied to spring barley, J. Environ. Qual., 28, 1610 1618, 1999.

Petrone, R. M., Waddington, J. M., and Price, J.: Ecosystem-scale flux of $\mathrm{CO}_{2}$ from a restored vacuum harvested peatland, Wetlands Ecol. Manag., 11, 419-432, 2003.

Perälä, P., Kapuinen, P., Esala, M., Tyynelä, S., and Regina, K.: Influence of slurry and mineral fertilizer application techniques on $\mathrm{N}_{2} \mathrm{O}$ and $\mathrm{CH}_{4}$ fluxes from a barley field in southern Finland, Agr. Ecosyst. Environ., 117, 71-78, 2006.

Pihlatie, M., Rinne, J., Lohila, A., Laurila, T., Aro, L., and Vesala, T.: Nitrous oxide emissions from an afforested peat field using eddy covariance and enclosure techniques, in: Proceedings of 12th International Peat Congress, edited by: Päivänen, J., Tampere, Finland, 6-11 June 2004, Vol. 2, 1010-1014, 2004.

Pihlatie, M., Rinne, J., Ambus, P., Pilegaard, K., Dorsey, J. R., Rannik, Ü., Markkanen, T., Launiainen, S., and Vesala, T.: Nitrous oxide emissions from a beech forest floor measured by eddy covariance and soil enclosure techniques, Biogeosciences, 2, 377387, doi:10.5194/bg-2-377-2005, 2005.

Pihlatie, M., Pumpanen, J., Rinne, J., Ilvesniemi, H., Simojoki, A., Hari, P., and Vesala, T.: Gas concentration driven fluxes of nitrous oxide and carbon dioxide in boreal forest soil, Tellus B, 59, 458-469, 2007.

Pihlatie, M. K., Kiese, R., Brüggemann, N., Butterbach-Bahl, K., Kieloaho, A.-J., Laurila, T., Lohila, A., Mammarella, I., Minkkinen, K., Penttilä, T., Schönborn, J., and Vesala, T.: Greenhouse gas fluxes in a drained peatland forest during spring frost-thaw event, Biogeosciences, 7, 1715-1727, doi:10.5194/bg-7-17152010, 2010.

Pilegaard, K., Mikkelsen, T. N., Beier, C., Jensen, N. O., Ambus, P., and Ro-Poulsen, H.: Field measurements of atmospherebiosphere interactions in a Danish beech forest, Boreal Environ. Res., 8, 315-333, 2003.

Pilegaard, K., Skiba, U., Ambus, P., Beier, C., Brüggemann, N., Butterbach-Bahl, K., Dick, J., Dorsey, J., Duyzer, J., Gallagher, M., Gasche, R., Horvath, L., Kitzler, B., Leip, A., Pihlatie, M. K., Rosenkranz, P., Seufert, G., Vesala, T., Westrate, H., and Zechmeister-Boltenstern, S.: Factors controlling regional differences in forest soil emission of nitrogen oxides ( $\mathrm{NO}$ and $\mathrm{N}_{2} \mathrm{O}$ ), Biogeosciences, 3, 651-661, doi:10.5194/bg-3-651-2006, 2006.

Post, W. M., Emanuel, W. R., Zinke, P. J., and Stangenberger, A. G.: Soil carbon pools and world life zones, Nature, 298, 156159, 1982.

Priemé, A. and Christensen, S.: Natural perturbations, dryingwetting and freezing-thawing cycles, and the emission of nitrous oxide, carbon dioxide and methane from farmed organic soils, Soil Biol. Biochem., 33, 2083-2091, 2001.

Regina, K., Nykänen, H., Silvola, J., and Martikainen, P. J.: Fluxes of nitrous oxide from boreal peatlands as affected by peatland type, water table level and nitrification capacity, Biogeochemistry, 35, 401-418, 1996.

Regina, K., Nykänen, H., Maljanen, M., Silvola, J., and Martikainen, P. J.: Emissions of $\mathrm{N}_{2} \mathrm{O}$ and $\mathrm{NO}$ and net nitrogen 
mineralization in a boreal forested peatland treated with different nitrogen compounds, Can. J. For. Res., 28, 132-140, 1998.

Regina, K., Syväsalo, E., Hannukkala, A., and Esala, M.: Fluxes of $\mathrm{N}_{2} \mathrm{O}$ from farmed peat soils in Finland, Eur. J. Soil Sci., 55, 591-599, 2004.

Regina, K., Pihlatie, M., Esala, M., and Alakukku, L.: Methane fluxes on boreal arable soils, Agr. Ecosyst. Environ., 119, 346352, 2007.

Repo, M., Susiluoto, S., Lind, S. E., Jokinen, S., Elsakov, V., Biasi, C., Virtanen, T., and Martikainen, P. J.: Large $\mathrm{N}_{2} \mathrm{O}$ emissions from cryoturbated peat soil in tundra, Nat. Geosci., 2, 189-192, doi:10.1038/NGEO434, 2009.

Rochette, P. and Eriksen-Hamel, N. S.: Chamber measurements of soil nitrous oxide flux: Are absolute values reliable, Soil Sci. Soc. Am. J., 72, 331-342, 2008.

Roehm, C. and Tremblay, A.: Role of turbines in the carbon dioxide emissions from two boreal reservoirs, Québec, Canada, J. Geophys. Res., 111, D24102, doi:10.1029/2006JD007292, 2006.

Saari, A., Heiskanen, J., and Martikainen, P. J.: Effect of the organic horizon on methane oxidation and uptake in soil of a boreal Scots pine forest, FEMS Microbiol. Ecol., 26, 245-255, 1998.

Saari, A., Smolander, A., and Martikainen, P. J.: Methane consumption in a frequently nitrogen-fertilized and limed spruce forest soil after clear-cutting, Soil Use Manage., 20, 65-73, 2004.

Saari, A., Smolander, A., and Martikainen, P. J.: Production of $\mathrm{N}_{2} \mathrm{O}$ in a repeatedly nitrogen- fertilized and limed spruce forest soil after clear cutting, in: Maaperän vuorovaikutukset, III Maaperätieteiden päivät, edited by: Siimes, K., Makkonen, K., Pietikäinen, J., Mattila, P., Penttinen, S., Esala, M., Helsinki, 13.-14 January 2005, Pro Terra No. 22, 75-76, 2005.

Saari, P., Saarnio, S., Kukkonen, J. V. K., Akkanen, J., Heinonen, J., Saari, V., and Alm, J.: DOC and $\mathrm{N}_{2} \mathrm{O}$ dynamics in upland and peatland forest soils after clear-cutting and soil preparation, Biogeochemistry, 94, 217-231, doi:10.1007/s10533-009-93201, 2009a.

Saari, P., Saarnio, S., Kukkonen, J. V. K., Akkanen, J., and Alm, J.: Are peatland forestry buffers hot spots of $\mathrm{N}_{2} \mathrm{O}$ emission?, in: 9th Finnish Conference of Environmental Sciences, edited by: Vakkilainen, K. and Pukkila, V., Lahti 14-15 May 2009, Finnish Society for Environmental Sciences, Markprint Oy, Lahti, 153$156,2009 b$.

Saarnio, S., Morero, M., Shurpali, N. J., Tuittila, E.-S., Mäkilä, M., and Alm, J.: Annual $\mathrm{CO}_{2}$ and $\mathrm{CH}_{4}$ fluxes of pristine boreal mires as a background for the lifecycle analyses of peat energy, Boreal Environ. Res., 12, 101-113, 2007.

Sagerfors, J., Lindroth, A., Grelle, A., Klemedtsson, L., Weslien, P., and Nilsson, $\mathrm{M}$.: Annual $\mathrm{CO}_{2}$ exchange between a nutrient poor, minerotrophic boreal mire and the atmosphere, J. Geophys. Res., 113, G01001, doi:10.1029/2006JG000306, 2008.

SCB, (Statistiska centralbyrån): Torv 2003, Produktion, användning, miljöeffekter, Statistiska meddelanden MI 25 SM 0401, 32 pp., 2004.

SCB, (Statistiska centralbyrån): Torv 2007, Produktion, användning, miljöeffekter, Statistiska meddelanden MI 25 SM 0801, 33 pp., 2008.

Schrier-Uijl, A.-P., Veraart, A. J., Leffelaar, P. A., Berendse, F., and Veenendaal, E. M.: Release of $\mathrm{CO}_{2}$ and $\mathrm{CH}_{4}$ from lakes and drainage ditches in temperate wetlands, Biogeochemistry, in pess, doi:10.1007/s10533-010-9440-7, 2010.
Shurpali, N. J., Hyvönen, N., Huttunen, J. T., Clement, R., Reichestein, M., Nykänen, H., Biasi, C., and Martikainen, P. J.: Cultivation of perennial grass for bioenergy use on a boreal organic soil - carbon sink or source?, Global Change Biol. Bioenergy, 1, 35-50, doi:10.1111/j.1757.2009.01003.x, 2009.

Shurpali, N. J., Hyvönen, N. P., Huttunen, J. T., Biasi, C., Nykänen, H., Pekkarinen, N., and Martikainen, P. J.: Bare soil and reed canary grass ecosystem respiration in peat extraction sites in Eastern Finland, Tellus B, 60, 200-209, 2008.

Shurpali, N. J., Verma, S. B., Kim, J., and Arkebauer, T. J.: Carbon dioxide exchange in a peatland ecosystem, J. Geophys. Res.Atmos., 100, 14319-14326, 1995.

Silvan, N., Regina, K., Kitunen, V., Vasander, H., and Laine, J.: Gaseous nitrogen loss from a restored peatland buffer zone, Soil Biol. Biochem., 34, 721-728, 2002.

Silvan, N., Tuittila, E.-S., Kitunen, V., Vasander, H., and Laine, J. Nitrate uptake by Eriophorum vaginatum controls $\mathrm{N}_{2} \mathrm{O}$ production in a restored peatland, Soil Biol. Biochem., 37, 1519-1526, 2005.

Sikström, U., Björk, R. G., Ring, E., Ernfors, M., Jacobson, S., Nilsson, M., and Klemedtsson, L.: Tillförsel av aska i skog på dikad torvmark i södra Sverige, Effekter på skogsproduktion, flöden av växthusgaser, torvegenskaper, markvegetation och grundvattenkemi. VÄRMEFORSK Service $A B$, Stockholm, 75 pp., 2009.

Soini, P., Riutta, T., Yli-Petäys, M., and Vasander, H.: Comparison of vegetation and $\mathrm{CO}_{2}$ dynamics between restored cut-away peatland and a pristine fen: Evaluation of the restoration success, Restor. Ecol., in press, doi:10.1111/j.1526-100X.2009.00520.x. 2009.

Solomon, S., Qin, D., Manning, M., Alley, R. B., Berntsen, T., Bindoff, N. L., Chen, A., Chisthaisong, A., Gregory, J. M., Hegerl, G. C., Heimann, M., Hewitson, B., Hoskins, B. J., Foos, F., Jouel, J., Kattsov, V., Lohmann, U., Maysuno, T., Molina, M., Nicholls, N., Overpack, J., Raga, G., Ramaswamy, V., Ren, J., Rusticucci, M., Sommerville, R., Stocker, T. F., Whetton, P., Wood, R. A., and Wratt, D. : Technical summary, in: Climate Change 2007: The physical Science Basis, Contribution of Working Group I to the fourth Assessment Report of the Intergovernmental Panel on Climate Change, 2007.

Soumis, N., Duchemin, E., Canuel, R., and Lucotte, M.: Greenhouse gas emissions from reservoirs of the western United States, Global Biogeochem. Cy., 18, GB3022, doi:2003GB002197, 2004.

Soussana, J. F., Allard, V., Pilegaard, K., Ambus, P., Amman, C., Campbell, C., Ceschia, E., Clifton-Brown, J., Czobel, S., Domingues, R., Flechard, C., Fuhrer, J., Hensen, A., Horvath, L., Jones, M., Kasper, G., Martin, C., Nagy, Z., Neftel, A., Raschi, A., Baronti, S., Rees, R. M., Skiba, U., Stefani, P., Manca, G., Sutton, M., Tubaf, Z., and Valentini, R.: Full accounting of the greenhouse gas $\left(\mathrm{CO}_{2}, \mathrm{~N}_{2} \mathrm{O}, \mathrm{CH}_{4}\right)$ budget of nine European grassland sites, Agr. Ecosyst. Environ., 121, 121-134, 2007.

Starck, M.: Peatlands and Climate Change, International Peat Society, Saarijärven offset Oy, Finland, 223 pp., 2008.

Struwe, S. and Kjøller, A. : Potential for $\mathrm{N}_{2} \mathrm{O}$ production from beech (Fagus silvaticus) forest soils with varying $\mathrm{pH}$, Soil Biol. Biochem., 26, 1003-1009, 1994.

St. Louis, V. L., Kelly, C. A., Duchemin, É., Rudd, J. W. M., and Rosenberg, D. M.: Reservoir surfaces as sources of greenhouse 
gases to the atmosphere: A global estimate, Bioscience, 50, 766775,2000

Sundh, I., Nilsson, M., Mikkelä, C., Granberg, G., and Svensson, B. H.: Fluxes of methane and carbon dioxide on peat-mining areas in Sweden, Ambio, 29, 499-503, 2000.

Suni, T., Rinne, J., Reissell, A., Altimir, N., Keronen, P., Rannik, Ü., Dal Maso, M., Kulmala, M., and Vesala, T.: Long-term measurements of surface fluxes above a Scots pine forest in Hyytiälä, southern Finland, 1996-2001, Boreal Environ. Res., 8, 287-301, 2003.

Syväsalo, E., Regina, K., Pihlatie, M., and Esala, M.: Emissions of nitrous oxide from agricultural clay and loamy sand soils in Finland, Nutr. Cy. AgroEcosyst., 69, 155-165, 2004.

Syväsalo, E., Regina, K., Turtola, E., Lemola, R., and Esala, M.: Fluxes of nitrous oxide and methane, and nitrogen leaching from organically and conventionally cultivated sandy soil in Western Finland, Agr. Ecosyst. Environ., 113, 342-348, 2006.

The Environment Agency of Iceland: National Inventory Report Iceland 2008; Submitted under the United Nations Framework Convention on Climate Change: Birna S. Hallsdóttir, Kristín Harðardóttir and Jón Guðmundsson, UST, 173, 2008.

The Environment Agency of Iceland: National Inventory Report Iceland 2009; Submitted under the United Nations Framework Convention on Climate Change: Birna S. Hallsdóttir, Kristin Harðardóttir, Jón Guðmundsson, Arnór Snorrason, UST, 2009.

Tremblay, A., Therrien, J., Hamlin, B., Wichmann, E. and LeDrew, L. J.: GHG emissions from boreal reservoirs and natural aquatic ecosystems, in: Greenhouse Gas Emissions - Fluxes and Processes: Hydroelectric Reservoirs and Natural Environments, edited by: Tremblay, A., Varfalvy, L., Roehm, C., and Garneau, M., Springer, 210-232, 2005.

Tuittila, E.-S. and Komulainen, V.-M.: Vegetation and $\mathrm{CO}_{2}$ balance in an abandoned harvested peatland in Aitoneva, southern Finland, Suo, 46, 69-80, 1995.

Tuittila, E.-S., Komulainen, V.-M., Vasander, H., and Laine, J.: Restored cut-away peatland as a sink for atmospheric $\mathrm{CO}_{2}$, Oecologia, 120, 563-574, 1999.

Tuittila, E.-S., Komulainen, V. M., Vasander, H., Nykänen, H., Martikainen, P. J., and Laine, J.: Methane dynamics of a restored cut-away peatland, Global Change Biol., 6, 569-581, 2000.

Tuittila, E.-S., Vasander, H., and Laine, J.: Sensitivity of C sequestration in reintroduced Sphagnum to water-level variation in a peat extraction peatland, Restor. Ecol., 12, 483-493, 2004.

Turunen, J.: Development of Finnish peatland area and carbon storage 1950-2000, Boreal Environ. Res., 13, 319-334, 2008.

Turunen, J., Tomppo, E., Tolonen, K., and Reinikainen, A.: Estimating carbon accumulation rates of undrained mires in Finland Ü- application to boreal and subarctic regions, Holocene, 12, 7990, 2002.

UNFCCC: Iceland; Land Use, Land-Use Change and Forestry (LULUCF), Submission to the AWG-LCA and AWG-KP, 5 December 2008 Accra Climate Change Talks 2008, Accra, Ghana, 21-27 August 2008, http://unfccc.int/files/kyoto_ protocol/application/pdf/icelandlulucf051208.pdf, last access: 14 September 2010, 2008.

Valentini, R., Matteucci, G., Dolman, A. J., Schulze, E.-D., Rebmann, C., Moors, E. J., Granier, A., Gross, P., Jensen, N. O., Pilegaard, K., Lindroth, A., Grelle, A., Bernhofer, C., Grünwald, T., Aubinet, M., Ceulemans, R., Kowalski, A. S., Vesala, T., Rannik,
Ü., Berbigier, P., Loustau, D., Guðmundsson, J., Thorgeirsson, H., Ibrom, A., Morgenstern, K., Clement, R., Moncrieff, J., Montagnani, L., Minerbi, S., Jarvis, P. G.: Respiration as the main determinant of carbon balance in European forests, Nature, 404 861-865, 2000.

VAPO: Biomass dryer set to revolutionize peat production. http: //www.vapo.fi/eng/company/vapo_local_fuels/peat_production/ production_methods/new_production_technology/?id=1068, last access: 20 February, 2009.

Vasander, H., Tuittila, E.-S., Lode, E., Lundin, L., Ilomets, M., Sallantaus, T., Heikkilä, R., Pitkänen, M.-L., and Laine, J.: Status and restoration of peatlands in northern Europe, Wetland Ecol. Manag., 11, 51-63, 2003.

Virkajärvi, P., Maljanen, M., Saarijärvi, K., Haapala, J., and Martikainen, P. J. : $\mathrm{N}_{2} \mathrm{O}$ emissions from a boreal grass and grassclover pasture soils, Agr. Ecosyst. Environ., 137, 59-67, 2010.

von Arnold, K., Hånell, B., Stendahl, J., and Klemedtsson, L.: Greenhouse gas fluxes from drained organic forestland in Sweden, Scand. J. Forest Res., 20, 400-411, 2005a.

von Arnold, K., Weslien, P., Nilsson, M., Svensson, B. H., and Klemedtsson, L.: Fluxes of $\mathrm{CO}_{2}, \mathrm{CH}_{4}$ and $\mathrm{N}_{2} \mathrm{O}$ from drained coniferous forests on organic soils, Forest Ecol. Manag., 210, 239-254, 2005b.

von Arnold, K., Nilsson, M., Hånell, B., Weslien, P., and Klemedtsson, L.: Fluxes of $\mathrm{CO}_{2}, \mathrm{CH}_{4}$ and $\mathrm{N}_{2} \mathrm{O}$ from deciduous forests on organic soils, Soil Biol. Biochem., 37, 1059-1071, 2005c.

Votlendisnefnd Landbúnaðarráđuneytisin: Endurheimt votlendis 1996-2006, Skýrsla votlendisnefndar, Landbúnaðarráðuneytið 2006, 27. blaðsíður, Restoration of wetlands in Iceland 19962006, Report of the Ministry of Agriculture's wetland committee, 27 pp., 2006.

Waddington, J. M., Warner, K. D., and Kennedy, G. W.: Cutover peatlands: A persistent source of atmospheric $\mathrm{CO}_{2}$, Global Biogeochem. Cy., 16, 1002, doi:10.1029/2001GB001298, 2002.

Waddington, J. M. and Day, S. M.: Methane emissions from a peatland following restoration, J. Geophys. Res., 112, G03018, doi:10.1029/2007JG000400, 2007.

Wagner-Riddle, C., Hu, Q. C., van Bochove, E., and Jayasundara, S.: Linking nitrous oxide flux during spring thaw to nitrate denitrification in the soil profile, Soil Sci. Soc. Am. J., 72, 908-916, 2008.

Weslien, P., Kasimir Klemedtsson, Å., Börjesson, G., and Klemedsson, L.: Strong $\mathrm{pH}$ influence on $\mathrm{N}_{2} \mathrm{O}$ and $\mathrm{CH}_{4}$ fluxes from forested organic soils, Eur. J. Soil Sci., 3, 311-320, doi:10.1111/j.1365-2389.2009.01123.x, 2009.

WMO, (World Meteorological Organization): WMO Greenhouse gas bulletin, No. 4, 14 November, 2008.

Yli-Petäys, M., Laine, J., Vasander, H., and Tuittila, E.-S.: Carbon gas exchange of a re-vegetated cut-away peatland five decades after abandonment, Boreal Environ. Res., 12, 177-190, 2007.

Yu, K., Struwe, S., Kjøller, A., and Chen, G.: Nitrous oxide production and consumption potential in an agricultural and forest soil, Commun. Soil Sci. Plant, 39, 2205-2220, 2008.

Zha, T., Xing, Z., Wang, K.-Y., Kellomäki, S., and Barr, A.: Total and component carbon fluxes of a Scots pine ecosystem from chamber measurements and eddy covariance, Ann. Bot., 99, 345-353, doi:10.1093/aob/mc1266, 2007. 